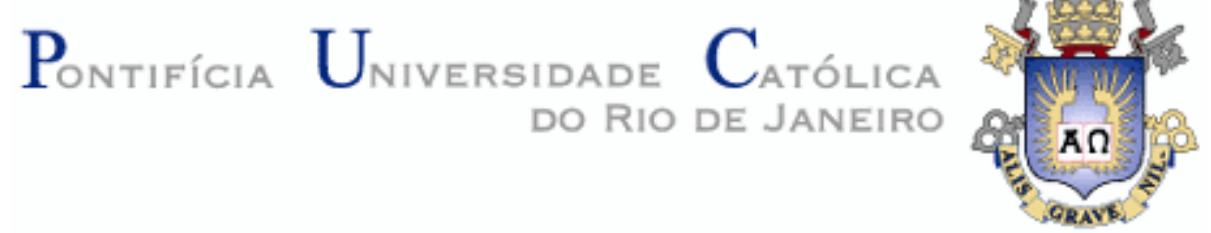

Roberto Alves de Oliveira

\title{
ALAIN BADIOU: DIFERENÇA E VERDADE NA REINVENÇÃO DO DOIS DO AMOR Estudos a partir da obra de Alain Badiou
}

Dissertação de Mestrado

Dissertação apresentada ao Programa de Pósgraduação em Filosofia do Departamento de Filosofia da PUC-Rio como parte dos requisitos para obtenção do título de Mestre em Filosofia.

Orientador: Prof. Edgar de Brito Lyra Netto

Rio de Janeiro Fevereiro de 2014 


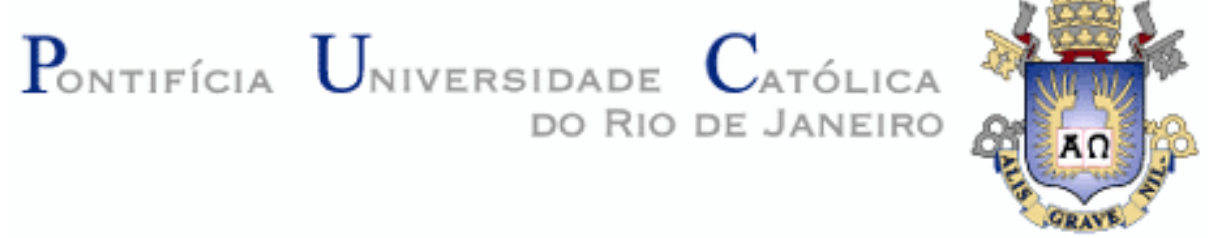

Roberto Alves de Oliveira

\title{
ALAIN BADIOU: DIFERENÇA E VERDADE NA REINVENÇÃO DO DOIS DO AMOR \\ Estudos a partir da obra de Alain Badiou
}

\begin{abstract}
Dissertação apresentada como requisito parcial para obtenção do grau de Mestre em Filosofia pelo Programa de Pós-graduação do Departamento de Filosofia do Centro de Teologia e Ciências Humanas da PUC-Rio. Aprovada pela Comissão Examinadora abaixo assinada.
\end{abstract}

\author{
Prof. Edgar de Brito Lyra Netto \\ Orientador \\ Departamento de Filosofia - PUC-Rio
}

Profa. Andrea Bieri

Departamento de Filosofia - Unirio

Prof. Pedro Duarte de Andrade Departamento de Filosofia - PUC-Rio

Profa. Denise Berruezo Portinari Coordenadora Setorial do Centro de Teologia e

Ciências Humanas - PUC-Rio

Rio de Janeiro, 14 de Fevereiro de 2014. 
Todos os direitos reservados. É proibida a reprodução total ou parcial do trabalho sem autorização da universidade, do autor e do orientador.

\section{Roberto Alves de Oliveira}

Licenciado em Filosofia pela PUC-Rio em 2010, com domínio adicional em cultura grecolatina. Bailarino e coreógrafo, com criações e participações em prestigiosas companhias europeias (Béjart Ballet Lausanne (Suíça), Stuttgarter Ballet, Deutsche Oper Berlin (Alemanha) e Balletto di Toscana (Itália), criou e dirige a DeAnima Ballet Contemporâneo. Em 2012 lecionou filosofia e dança na UFRJ (Faculdade de Dança e Desportos), e atualmente é professor de filosofia na EARJ (Escola Americana do Rio de Janeiro).

Ficha Catalográfica

Oliveira, Roberto Alves de

Alain Badiou: diferença e verdade na reinvenção do dois do amor: estudos a partir da obra de Alain Badiou / Roberto Alves de Oliveira ; orientador: Edgar de Brito Lyra Netto. - 2014.

110 f. ; $30 \mathrm{~cm}$

Dissertação (mestrado) - Pontifícia Universidade Católica do Rio de Janeiro, Departamento de Filosofia, 2014.

Inclui bibliografia

1. Filosofia - Teses. 2. Erótica 3. Ética. 4. Diferença. 5. Verdade. I. Lyra Netto, Edgar de Brito. II. Pontifícia Universidade Católica do Rio de Janeiro. Departamento de Filosofia. III. Título.

CDD: 100 
Para Luiz Paulo, meu companheiro de vida e viagem. 


\section{Agradecimentos}

Ao professor Edgar Brito Lyra Netto pela orientação e estímulo ao trabalho.

À PUC-Rio.

Ao programa de bolsa do CAPES, pelos auxílios concedidos, sem os quais este trabalho não poderia ter sido realizado.

A todos os professores do Programa de Pós-graduação da PUC-Rio.

Aos colegas, alunos e ex-alunos do mesmo Programa.

Às secretárias do departamento de filosofia Edna e Dinah.

Às professoras Irley Franco, Maura Iglesias, Kátya Muricy.

Ao professor Lucas Soares pela introdução a Alain Badiou.

Aos professores Pedro Duarte de Andrade e Andrea Bieri.

Ao professor e amigo Amílcar Torrão Filho pela luz e encorajamento recebidos.

Às amigas Rosane Lima e Rosália Verlangieri por tudo, pelo todo e pelo sempre.

À Tima e Alci, Evoé: Eros é...! 


\section{Resumo}

De Oliveira, Alves Roberto; Lyra Netto, Edgar Britto. Alain Badiou: diferença e verdade na reinvenção do dois do amor. Rio de Janeiro, 2014. 102p. Dissertação de Mestrado - Departamento de Filosofia, Pontifícia Universidade Católica do Rio de Janeiro.

O amor e sua relação com a diferença são as premissas de análise para a investigação desta condição da filosofia no pensamento de Alain Badiou, traçando ainda suas correspondências com outros pensadores da contemporaneidade (Michel Foucault, Claudine Haroche e Zygmunt Bauman, entre outros) sobre o tema. Este estudo inicia-se com uma breve introdução à sua biografia, militância e pensamento, analisando ainda o amor como verdade e instrumento na construção e reinvenção de um novo homem, bem como novas formulações a partir de um pensamento livre sobre o tema.

\section{Palavras- chave}

Erótica; ética; diferença; verdade. 


\section{Abstract}

De Oliveira, Alves Roberto; Lyra Netto, Edgar Britto ((Directeur de recherche). Alain Badiou: différence et vérité dans la réinvention du deux de l'amour. Rio de Janeiro, 2014. 102p. Dissertation de Maîtrise Departamento de Filosofia, Pontifícia Universidade Católica do Rio de Janeiro

L'amour et son rapport à la vérité et à la différence sont les premisses d'analyse pour enquêter cette condition de la philosophie dans la pensée d'Alain Badiou, en cherchant encore leurs connexions avec d'autres penseurs contemporains (Michel Foucault, Claudine Haroche et Zygmunt Bauman parmi d'autres) sur le sujet. Cet étude commence par une introduction à sa biographie, activisme et pensée, ainsi qu'à son affirmation que l'amour est une verité est aussi un instrument dans la construction et reinvention d'un nouveau homme, ainsi que de nouvelles formulations sur à partir d'une libre pensée sur le sujet.

\section{Keywords}

Érotique; éthique; différence; vérité 


\section{Sumário}

$\begin{array}{ll}\text { 1. Introdução } & 9\end{array}$

\section{Capítulo I - Alain Badiou: Vida e Obra}

2. Biografia e obra 18

3. Alain Badiou e a Filosofia 26

3.1 A filosofia e a verdade 28

4. Ontologia e a matemática 34

5. Acontecimento (L'évenement) 38

5.1 Lacan, um acontecimento no amor, segundo Badiou 42

6. Sujeito e Verdade 45

\section{Capítulo II: O Amor}

7. A reinvenção do Dois do amor 50

8. O amor na obra de Badiou $\quad 55$

9. Amor e diferença 57

10. Amor e o Dois 59

11. Amor e as posições homem e mulher 66

11.1 A posição homem $\quad 69$

11.2 A posição mulher $\quad 70$

12. Amor e acontecimento $\quad 72$

13. Amor e sujeito 74

13.1 Os três sujeitos possíveis do amor $\quad 76$

14. Amor e fidelidade 78

15. O amor, a verdade e a ideia 79

\section{Capítulo III: A Reinvenção}

16. O homem hoje e a sua reinvenção 84 
17. Foucault: a reinvenção do desejo e do Dois

\section{Capítulo IV: Conclusão}

18. Conclusão

99

19. Referências bibliográficas 


\section{Introdução}

O amor se edifica social e temporalmente, inserido na história dos homens. Há um determinismo que se faz presente no ritmo das relações afetivas, coerente com a dinâmica das instituições, núcleos familiares e sociedades. Pensar hoje, o amor, demonstra-se tarefa particular e difícil se levarmos em conta o descartável das relações, as dinâmicas inter-relacionais das redes sociais e o hedonismo material consumista - fatores que condicionam, como legendas apócrifas, o que iremos procurar e encontrar, por vezes já morto, no amor. Tratamos o amor a partir de pressupostos e de ideias pré-concebidas, já que cabe a todos nós, um dia ou outro, no exercício do humano, lançarmo-nos à conquista do amor. Mas o que amamos? O que buscamos no outro? Existem condições a priori para se pensar o amor? Podemos ainda pensá-lo a partir de critérios de verdade - ou como valor de uma verdade pessoal e intransferível? O que buscamos no outro: o que nos é diferente, ausência ou criamos pelo amor um espaço para que nossa diferença se afirme e cresça como condição à diferença do outro? Diferença, verdade e reinvenção, creio, me parecem ser as palavras centrais da questão a conduzir o meu pensamento e esta dissertação de mestrado.

Pensarmos a diferença, nos dias de hoje, nos traz em mente a questão da política, de como as diferenças são hoje organizadas e respaldadas por constituições e direitos universais do homem. Sem esse espaço entre os homens, para que a diferença exista e coexista, não existiria um caminho real para a política. A filosofia e a política se ocupam do homem em todas as suas afirmações e condições, "e todas essas afirmações estariam corretas se houvesse apenas um homem, dois homens, ou apenas homens idênticos" - nas palavras de Hannah Arendt ${ }^{1}$. A política, como a filosofia, nasceria deste espaço vazio entre os homens, que regularia as verdades procedentes das relações humanas. Por nascer fora das relações, a política e a filosofia carecem de uma substância original. Como também a arte. E o amor. Não há assim verdade nelas, já que todas atuam a partir da verdade dos homens, direcionando-os na construção de um mundo onde essas verdades (ou diferenças) possam coexistir pacificamente.

\footnotetext{
${ }^{1}$ Cf. ARENDT, O que é a política, p. 21, 1993
} 
Considerarmos os homens na sua diversidade absoluta - e criarmos o espaço para a sua manifestação plena como indivíduo - só pode ser feito se considerando a verdade, manifestamente plural, também como absoluta. Hannah Arendt pensa toda verdade como pluralidade dentro do sentido da igualdade - e toda igualdade como pluralidade dentro do sentido da diferença. Mas como se pensar, hoje, o amor: há que se tê-lo respaldado pela política? Como regularizar algo que deveria ser livre e não institucional?

A verdade do amor para Alain Badiou é pensada a partir do vazio da verdade, a partir de uma dinâmica relacional que pode sempre se reinventar. Será na relação com o outro livre para amar que será possível pensarmos a subjetividade no seu valor e fundamento como diferença, já que alicerçado para se relacionar também consigo mesmo. Mas quais seriam os empecilhos primários para este processo? A organização e abrigo das diferenças encontram os primeiros percalços a partir do núcleo familiar, o primeiro a catequizar e castrar a diferença em prol do mesmo na suposta duplicação dos laços e traços familiares de parentesco. Há depois o colégio, a literatura, o cinema, o vídeo, a canção de amor, as ciências sociais, a psicologia... - a cultura, enfim, a nos conduzir à assimilação do mesmo do e no amor. Somos catequisados a receber o amor amado, pronto, com receita e bula, posologia e efeitos colaterais, com garantia de serviços - mas sem duração preestabelecida... O social nos engessa, e as instituições parecem destituir o homem de seus valores de conduta mais espontâneos. Michel Foucault olha a situação como que limitada pela construção institucional (e física) do social ocidental:

O exército, a burocracia, a administração, o ensino (no sentido moderno da palavra) não podem funcionar com relações intensas. Creio que se pode observar em todas estas instituições certo esforço por reduzir ou limitar estas relações afetivas. ${ }^{2}$

Há uma urgência no resgate do amor, para uma retomada de uma subjetividade mais ampla, leve e oxigenada do homem contemporâneo. Há que se pensar o amor como premissa de uma existência livre, em que os afetos possam de

\footnotetext{
${ }^{2}$ Cf. FOUCAULT, Dits et écrits IV, p. 74, 1994
} 
novo estabelecer novos parâmetros relacionais, abrindo o pensamento e a pragmática das relações numa reinvenção e recriação de si. Estamos infelizmente intoxicados com a dinâmica dos relacionamentos, somos letrados no abecedário das condutas sociais, espremidos pelo institucional midiático das imagens que nos catequisam na idolatria e construção de nós mesmos como imagem, como sujeitos reprodutores de técnicas de prazer, afeto e sexo.

Foucault nos convoca a irmos além da nossa condição natural, produzindo algo de novo ainda não conhecido, no pensamento da diferença como sítio possível de transformação e ascese ${ }^{3}$. Para ele, o amor é uma prova capaz de nos modificar, na criação de um jogo com a verdade. Uma ascese e exercício de subjetividade cujo objetivo maior é o de se desprender de si sem renegar o que temos de mais genuíno e precioso: a nossa relação com o prazer (ou a liberdade, já que ambos estão condicionados para o autor) num encontro no devir entre aquilo que ainda não é, no pensamento, o que ainda não se é na vida ${ }^{4}$. Mas o mundo, hoje, trinta anos depois de Foucault, não é o mais o mesmo.

Para Claudine Haroche, o que constitui a hipermodernidade é um desengajamento do indivíduo que influencia de forma insidiosa as relações entre sensação e a consciência, reflexão e os sentimentos, já que há um questionamento sobre os limites do eu e sobre a própria capacidade de sentir ${ }^{5}$. Estaríamos, segundo a autora, perdendo a capacidade de criarmos pontos concretos de referência emotiva, devido ao excesso de fluidez nas relações. O eu não se inseriria mais numa construção possível de vínculos afetivos - fundamental para a capacidade de engajamento nas relações interpessoais. A autora questiona se estaríamos submetidos a um deslocamento constante e infinito, o que faz com que o indivíduo se caracterize pela esquiva e carência de vínculos, na fugaz construção de relações efêmeras e fragmentadas: "A ininteligibilidade, a perda de sentido na relação com os outros e

\footnotetext{
${ }^{3}$ Cf. FOUCAULT, DE IV, pg 74

${ }^{4}$ Cf. HALPERIN, Saint Foucault, p. 90, 1995

${ }^{5}$ Cf. HAROCHE, A Condição Sensivel, p, 131, 2008
} 
consigo próprio, revelaria um entrave, um declínio e mesmo uma incapacidade não tanto de exprimir sentimentos, mas de experimentá-los, de senti-los? ${ }^{6,}$

Badiou identifica uma crescente insatisfação na forma volátil, superficial e descartável em como se dão os relacionamentos amorosos nos dias de hoje, ou ainda na maneira como a política trata de organizar do amor entre as minorias, sempre levando em consideração arquétipos prévios, com pouco olhar para as diferença reais que ali se apresentam (como no caso das relações homoafetivas). $\mathrm{O}$ autor nos mostra como o amor e a construção do Dois do amor podem ser reais e espontâneos instrumentos de potência do indivíduo, capazes por conduzi-lo além de um hermetismo individualista, numa visão mais generosa para com a vida e os afetos, levando-o a uma visão do outro - e de si mesmo - como potência geradora de novos valores ${ }^{7}$.

Tratamos o amor como um bem de consumo descartável, ausente de vínculos, do sentido do compromisso e da dedicação, da dilatação temporal que só um sentimento como o amor pode erigir. A construção da identidade assumiu a forma de uma experimentação infindável, com pouco diálogo e condições para uma subjetividade mais rica, leve, compartilhada. Almejamos uma imagem inatingível de perfeição e juventude, mas não conseguimos ainda lidar com o outro naquilo que ele possui de mais fundamental e insubstituível: sua diferença. Dois mil e quatrocentos anos depois e a partir de Platão, Badiou retoma o diálogo ao acontecimento do amor, com seus procedimentos de construção de verdade, resgatando sua posição como condição para a filosofia. Um dos poucos pensadores na contemporaneidade a se dedicar a atribuir um estatuto de verdade à questão, seu pensamento abre caminho para se repensar a mais importante e aporética das manifestações de afetividade do homem. Influenciado por Platão, Georg Wilhelm Friedrich Hegel, Jacques Lacan e Gilles Deleuze, sua filosofia procura expor o sentido do potencial de uma inovação

\footnotetext{
${ }^{6}$ Cf. HAROCHE, A condição sensível, p. 131, 2008

${ }^{7}$ Cf. BADIOU, Éloge de l'Amour, 2009
} 
radical (revolução, transfiguração, acontecimento ${ }^{8}$, invenção) em cada situação, inserida no pensamento como instrumento à ação e transformação.

Palavras de Alain Badiou sobre o amor, de forma espontânea e direta em entrevista realizada por Eduardo Febbro, em 05.12.2012, para o site Carta Maior:

$\mathrm{O}$ amor é um tema essencial, uma experiência total. $\mathrm{O}$ amor está ameaçado pela sociedade contemporânea. O amor é um gesto muito forte porque significa que é preciso aceitar que a existência de outra pessoa se converta em nossa preocupação 9 .

E seguindo seu pensamento e palavras, na mesma entrevista:

(...) Observemos como se organizam as relações nestes portais de internet onde as pessoas entram em contato: o outro já vem em fatias, um pouco como a vaca nos açougues. Seus gostos, seus interesses, a cor dos olhos, o corte dos cabelos, se é grande ou pequeno, loiro ou moreno. Vamos ter uns 40 critérios e, ao final, vamos nos dizer: vou comprar este. É exatamente o contrário do amor. O amor é justamente quando, em certo sentido, não tenho a menor ideia do que estou comprando ${ }^{10}$.

E ainda:

(...) O amor deve reafirmar o fato de que está em ruptura com o conjunto das leis ordinárias do mundo contemporâneo. O amor deve ser reinventado como valor universal, como relação em direção da alteridade, daquilo que não sou eu e onde a generosidade é obrigatória ${ }^{11}$.

\footnotetext{
${ }^{8} \mathrm{O}$ termo acontecimento (l'événement), em Badiou, é de capital importância na análise de sua obra e pensamento; mas como o foco principal desta escrita é sobre a reinvenção do dois do amor, optou-se assim por um tratamento transversal ao tema, a partir de suas relações com o amor.

${ }^{9}$ Cf.BADIOU, entrevista Comunismo é a ideia de emancipação de toda humanidade, de 05/02/2012, feita por Eduardo Febbro em http://www.cartamaior.com.br/?/Editoria/Internacional/-O-comunismo-ea-ideia-da-emancipacao-de-toda-humanidade-/6/18598

${ }^{10}$ Idem

${ }^{11}$ Idem
} 
Badiou identifica tensões neste processo de reinvenção da verdade: onde quer que se crie a verdade, haverá algo a recalcar e opor-se a este processo. O autor fala da política identitária, do engessamento possível a partir da institucionalização dos afetos e escolhas das minorias. Alain Badiou vê problemas neste procedimento, já que um antagonismo natural nasce pela cultura reprimindo a arte, bem como a técnica vem obliterar a palavra ciência - ou ainda como o sexo (centrado nas práticas e técnicas genitais de prazer e nos papéis sócio-performáticos do sexo - hétero, homo, bi, trans, etc...) oblitera o amor. Badiou identifica uma tensão de opostos entre a cultura-técnica-gestão-sexualidade (discursos identitários, justificados pelos processos mercantis de consumo e produção, de gestão autoritária pelos canais políticos dominantes da democracia) e os procedimentos de saber arte-ciênciapolítica-amor - estes, relacionados com a produção e pensamento de verdade do espontâneo do homem. Há que existir uma perpendicularidade, a da verdade, nos subconjuntos minoritários, legitimando novas práticas de reinvenção de afeto e alteridade $^{12}$. Jacques Rancière, na introdução à obra L'Être et l'Événement, de Badiou, nos chama a atenção para vermos a obra filosófica do autor como um lugar construído para ainda uma vez abrigarmos a verdade, numa construção em que o pensamento filosófico poderia reencontrar seu poder real de intersecção com a vida e com a ação. Rancière identifica os pontos de apoio no pensamento de Badiou para a construção de um platonismo do múltiplo - em especial no amor e na imanência das relações subjetivas ${ }^{13}$.

O amor - múltiplo, plural, incondicionado - é uma criação humana, e debruçar-se sobre o tema, a partir da ideia de seu acontecimento, é pensarmos o reinventar possível das relações humanas no presente a partir da ideia de recomeço, de um novo inaugural.

A obra de Alain Badiou dialoga com diversos momentos da filosofia, mas em especial com a obra de Platão na questão do amor como ideia e como construto mental simbólico - só que na e a partir da imanência. A análise e a atualização do uso das premissas platônicas que embasam o pensamento de Badiou (como o real como

\footnotetext{
${ }^{12}$ Cf. BADIOU, São Paulo, p.19, 2009

${ }^{13}$ Cf. BADIOU, L'être et l'évenement, 1988
} 
lugar de imanência das questões subjetivas, e a ideia como ideal de transcendência no real, na sua aplicabilidade positiva e fonte de referência à subjetividade) servem de base para também identificar o amor. Há um momento transversal, por excelência, entre a obra dos dois filósofos: o encômio de Alcibíades no Banquete. A verdade (e diferença) do amor entre Alcibíades e Sócrates é publicamente anunciada aos participantes do symposium como discurso do dois, calcada a partir da impossibilidade, diferença e contradições relacionais entre as partes. Amado e amante, nessa estória, são papéis que se perdem e se confundem no real dos afetos das personagens. $\mathrm{O}$ que vemos na mais personalizada declaração de amor da obra platônica é a identificação em que o outro "é o absolutamente edificado como outro" ", são as raízes de uma primeira subjetividade possível e real diferença nos personagens. Sócrates e Alcibíades são condutores e protagonistas de suas identidades de um amor imanente, latejante na sua individualidade. Há uma certa desorganização, um desconforto estratégico no interior no encômio de Alcibíades, que constrói a própria diferença e uma outra noção de verdade dentro da obra de Platão - produzindo uma série de deslocamentos e espaços vazios que se propagaram no devir da obra, que ecoam nos escritos de Badiou sobre a questão.

O que Platão percebeu de maneira inaugural foi a força do amor como condição para o saber, seu potencial de nos levar para além de nós mesmos, seja pela manía (loucura) no $\mathrm{Fedro}^{15}$, já que um delírio superior e divino, ou ainda no Banquete $^{16}$, onde as impressões sensíveis são imagens de um modelo hierarquicamente superior e eterno, onde a imutabilidade e permanência são as referências para os particulares sensíveis que do divino participam. Conduzir os homens para além da mera realização de seus desejos e sexualidade é o objetivo de Platão na sua pedagogia dos sentidos. A resposta ao jogo erótico entre as partes (amados - eromenoi - e amantes - erastai) era a experiência emocional mais forte que um homem grego poderia experimentar: este estímulo inicial de um efebo a um

\footnotetext{
${ }^{14}$ Cf. LÉVINAS, Totalidade e Infinito, p. 44, 1987

${ }^{15}$ Cf. PLATÃO, Fedro, 245b e 499d-e, 2010

${ }^{13}$ Cf. PLATÃO, O Banquete, 210d - 212a, 1950
} 
homem mais velho era o início da relação pupilo-mestre, a base para uma cooperação intelectual mais intensa - artifício este usado por Platão para iniciar a digressão filosófica em tantos de seus diálogos.

Platão escreveu sua obra como um pensador centrado nas questões de seu tempo, ora como um revolucionário a tentar se sobrepor à tradição didática iniciada por Homero e os poetas arcaicos, ora como um crítico refletindo sobre como deveria ser vivida a vida, da melhor e mais justa maneira, na Atenas clássica. Ele será, por excelência, o filósofo que terá eros como seu mediador direto na formação deste homem grego da Atenas do século IV a.C., reescrevendo os códigos de corte da época na busca de novos critérios de verdade sobre a questão. A erótica platônica apresentase como um processo de conversão, tanto para o discípulo quanto para o mestre, na busca do que lhes falta: o caminho à verdade.

Platão e Badiou são como pontas de um mesmo iceberg, onde passado e presente são as extremidades do pensamento filosófico sobre a questão. Numa entrevista datada de 1999, Alain Badiou diz permanecer convencido de que as questões com as quais Platão estruturou aquilo que é conhecido por filosofia são as corretas, e que o mundo das verdades, tudo ponderado, tem mudado pouco desde essa invenção $^{17}$. Vivemos e amamos de acordo com a ideia, consoantes com a transcendência de um valor universal, levados pela ideia de amor pelo próprio amor como creu também Santo Agostinho ${ }^{18}$.

O amor é a brecha de descontinuidade no presente, o novo que se insere no contínuo do tempo: assim amamos. Para o autor, Platão formulou uma operacionalidade do pensamento, uma afiliação do saber a uma proposta específica de pensamento e de criação de verdade. A concepção de Badiou adicionaria aqui outro óbvio arremate: as coisas se apresentam como de fato são justamente porque se abandonou a elaboração da ideia (eidos) de valor metafísico, o que possibilitou a transformação do mundo em outros mundos. E a reinvenção do amor também.

${ }_{17}$ Cf. HALLWARD, Badiou: a Subject to Truth, p. 5, 2003

${ }^{18}$ Cf. AGOSTINHO, Os pensadores, Ed. Abril, 1973 
A reinvenção do Dois do amor e sua relação com a verdade e a diferença são as premissas de análise para se investigar uma das quatro condições da filosofia (juntamente com a ciência, a política e as artes) reconhecidas por Badiou, o amor, e suas correspondências com outros pensadores da contemporaneidade (Michel Foucault, Claudine Haroche, Zygmunt Bauman, entre outros).

Essa investigação se dará em um primeiro momento identificando na produção do autor as bases teóricas de seu sistema que alicerçam e solidificam a compreensão do pensamento e do tema proposto. Não se trata de expor aqui de maneira plena e exaustiva (já que uma dissertação de mestrado) o sistema de Badiou na sua completude, cuja abrangência é enorme. Mas ao escolher o amor como tema desta dissertação, vejo que sou levado a considerar a sua obra pelo viés do todo, já que o todo do amor está estruturado dentro de um sistema de pensamento: da sua ontologia do múltiplo às premissas teóricas da filosofia e produção de verdade (filosofia, diferença, acontecimento, verdade etc...); da análise mais profunda dos elementos do amor em seu pensamento (disjunção, sujeito, fidelidade, o reativo do amor, o obscuro do amor, posições sexuadas, etc...) às questões do homem contemporâneo e da tradição sobre o tema. Sua obra restaura uma posição perdida da filosofia como pensadora do amor como proposição existencial que desloca formas historicamente inscritas (como a família, o matrimônio, o desejo do sujeito) para depois inseri-las em novos modelos de afeto com sua ideia do Dois do amor.

Desterritorialização, experimentação, reinvenção: as palavras-chave do amor badiouniano. A filosofia é a grande tradutora, para o autor, deste processo causado pela ruptura do encontro amoroso. Este estudo, um primeiro momento de reflexão sobre o pensamento do acontecimento da verdade do amor segundo Alain Badiou, inicia-se com uma breve introdução à sua vida, obra e pensamento, bem como sua militância e crença na realidade da experiência amorosa (esta última, enfatizada na sua produção filosófica dos últimos anos, em especial a partir de 1992 com a publicação de Conditions). 


\section{Capítulo I - Alain Badiou: Vida e Obra}

\section{Biografia e obra}

A obra de Alain Badiou emerge a partir do momento pós-estruturalista francês, dialogando diretamente com pensadores como Jean-Paul Sartre, Jacques Lacan, Louis Althusser, Michel Foucault e Gilles Deleuze, entre outros. Se a obra de um filósofo começa tantas vezes a repensar a própria raison d'être da filosofia, a sua se desenvolve e se promove em diferentes horizontes do pensamento, cuja abrangência vai desde a filosofia contemporânea, psicanálise, estudos em artes (poesia, cinema, teatro, dança, artes plásticas), história e ontologia, até a filosofia política e as questões sobre a ética científica. E claro, last but not least, o amor. Seu pensamento e obra são assim visitados por diferentes vertentes, acadêmicas e não acadêmicas, e as referências à sua produção se desdobram graças à força de seus argumentos e ao poder crítico de suas inferências. Tanto na filosofia analítica quanto na contemporânea, vemos sua arguta análise indo além do mero papel de crítico sofístico de temas controversos. Maoísta, marxista de primeira - mas não de última hora, profundo pensador da obra de Pascal, Platão e Lacan e de poetas como Mallarmé e Pessoa, dedica-se à eleição de verdades universais possíveis no horizonte da produção do pensamento crítico de hoje, deixando abertas brechas para a plenitude passional da existência de um homem através do amor.

Não sem resistências ao longo de sua carreira, ocupa sempre uma posição controversa no cenário mundial filosófico, em particular na França, seu país de

origem. É pela marginalidade de seu pensamento que sua notoriedade se afirma, já que em constante debate e oposição às orientações francesas e anglo-saxãs da filosofia. Ciente de sua posição marginal, seus alvos e ataques se multiplicam constantemente, em temas como a negação do pensamento metafísico platônico, hegeliano e marxista - que, segundo ele, seriam precursores do totalitarismo político 
-, ou ainda quando discursa sobre Auschwitz, negando a necessidade de uma virada no pensamento filosófico a partir da eclosão do nazismo e do holocausto.

Sua hipótese central sobre a ontologia (O Ser e o evento, 1988) é apresentada a partir da matemática, que para o autor é a ciência do ser-enquanto-ser - daí a equação matemática $=$ ontologia . Só haveria o que saber do ser, portanto, se algo for matematicamente pronunciável. O autor, ainda assim, desvincula a matemática da verdade, já que para ele toda verdade é pós-eventual, escapa da ontologia e é dependente do evento ${ }^{19}$.

Sua afirmação categórica contra o comunitarismo - ou contra a ideia de identidades, seja ela qual for - só se supera pela sua hostilidade aos procedimentos morais e jurídicos de classificação e normatização das diferenças (sejam elas culturais, sexuais, morais, políticas ou filosóficas).

São claros os pontos de interseção entre a produção de seu pensamento e a vivência de seu tempo, conjugando militância política com militância filosófica, no resgate do papel do filósofo pensador da pólis inaugurado por Platão, em profunda sintonia com os eventos e contexto de seu tempo. Obra e pensador caminham juntos, traçando no decorrer dos anos uma radiografia destes momentos que marcaram sua geração profunda e organicamente.

Alain Badiou nasce em Rabat, no Marrocos, em 1937, na época um protetorado francês. Seus pais, ambos franceses e acadêmicos oriundos da prestigiosa École Normale Supérieure, são seguramente a influência para a escolha dos estudos do autor: se sua mãe possuía formação em literatura francesa e seu pai em matemática, a filosofia pareceu assim combinar e refletir a paternidade conceitual de berço. Será pelo seu percurso e filiação entre a literatura e a matemática que seu pensamento se lançará aos estudos da filosofia, ingressando na mesma École Normale Supérieure de seus pais.

Se ao ingressar na filosofia sua primeira grande influência era Sartre (que reunia tanto das qualidades e talentos que um dia iriam modelar igualmente a

${ }^{19}$ Cf. BADIOU, Alain, O Ser e o evento, p.279, 1988 
produção e pessoa pública de Badiou - combinando filosofia com produção teatral, prosa, ficção e ativismo político), será na ENS, nos idos de 1950 que este ilustre pied noir terá seu primeiro e reconhecido mestre e influência: Louis Althusser. O psicanalista Jacques Lacan será o outro grande pensador que causará enorme impacto e interesse em Badiou, mesmo sem nunca ter frequentado nenhum dos seminários do autor ou consultórios de atendimento psicanalítico. Badiou interessa-se de imediato pela obra de Lacan, o que influencia toda a articulação de seu pensamento e obra, em especial suas reflexões sobre o amor, sexualidade e diferença.

Em 1960 lança-se como jornalista, escrevendo a respeito da greve de trabalhadores na Bélgica. Entre 1966-67 trabalha como professor de filosofia em Reims, até ser aceito na Universidade de Paris VIII / Vincennes, em 1969 (centro de estudos criado após os eventos de maio de 1968 e notório pelas posições radicais e inovadoras da filosofia francesa de então). Será em Vincennes que Badiou terá um maior contato com acadêmicos como Michel Serres, Jean-François Lyotard, François Chatelêt e Gilles Deleuze - de quem escreverá posteriormente polêmico estudo sobre obra e vida ${ }^{20}$. Sua primeira publicação, de forte influência sartriana, ocorre em 1964, Almagestes, com a renomada Éditions du Seuil, líder das produções de vanguarda de então, sobre a astronomia de Ptolomeu. Sem nenhuma ressonância maior, esta obra permanece suspensa entre o experimentalismo e a ficção literária. O mesmo se segue também com a sua continuação, Portulans, publicada em 1967. Sartre é ainda e sempre a grande veia conceitual e inspiração destas obras, onde os personagens parecem sempre engajados conceitualmente em distintas vertentes filosóficas. Um terceiro volume deveria completar esta primeira trilogia, nunca escrita, mesmo que em 1977 outra obra de ficção do autor ganhasse vida: Calme bloc ici-bas. Mas não seria na literatura que Alain Badiou teria seu primeiro momento de reconhecimento público como pensador e figura pública. Ainda no círculo do ENS, nos anos 60, Badiou se envolve ativamente com um grupo de estudantes que publicavam um jornal Les cahiers pour l'analise.

\footnotetext{
${ }^{20}$ Cf. BADIOU, La clameur de l'être, 1997
} 
O que permeia os escritos e artigos de então é uma forte influência marxista e estruturalista, ou de temas oriundos da psicanálise e filosofia da linguagem. Jacques Lacan, Michel Foucault, Jacques Derrida, Louis Althusser e Georges Canguillem são alguns dos autores também publicados junto com os artigos de estudantes como Badiou. Seus primeiros artigos filosóficos, escritos para este jornal (Subversion infinitesimal, de 1968), contribuem positivamente na escritura de seu primeiro livro filosófico, Le concept de modéle, em 1969. Mas os anos 60, com toda a gama de transformações e eventos sociais, como maio de 68 , teriam mais a contribuir na vida de Alain Badiou. Muito mais.

Alain Badiou não traça um discurso paralelo, distanciado de seu tempo: sua militância é o ponto de fuga para a produção de seu pensamento, já que inserida real e concretamente na interseção de uma política presencial, no devir dos dias. Sua militância é a causa imaterial e eficiente de seu pensamento sobre a questão, condicionando toda a sua reflexão sobre a questão. $O$ que autor vislumbra são as necessidades reais de uma causa política, suas exigências e contingências próprias, distante da verticalidade de uma teoria política sobre a questão. É na horizontalidade do confronto e da ação que sua visão se desvincula dos teóricos particulares, almejando um horizonte maior - de valores e verdades universais sobre a situação. $O$ autor tenta, como nenhum outro, possivelmente, uma linearidade e paralelismo entre prática e pensamento, acerto e erro, entre filosofia e o real da coisa pública. Se maio de 1968 é a cristalização para Badiou do que será futuramente um dos pontos principais de sua obra, un évenement (um acontecimento), será na militância que se articulará outro ponto axial de seu pensamento: la fidelité (a fidelidade). Se o autor abstrai tais momentos históricos num processo de subtração direta à filosofia ele mantém ainda assim tais categorias como processos condicionantes, com valor de verdade, para que se concretize a prática filosófica ${ }^{21}$. Esta coerência guiará os passos e pensamentos do autor entre sua vida e obra, teoria e prática, realizando este binômio

\footnotetext{
${ }^{21} \mathrm{Cf}$. BADIOU, L'être, l'événement, la militance, entrevista feita por Nicole-Édith Thévenin, primeira publicação em dezembro de 1991 e posteriormente em junho de 2004, no site http://multitudes.samizdat.net/L-etre-l-evenement-la-militance.
} 
não só na política, mas também no amor e na arte, ou ainda nas suas análises sobre ciência.

Maio de 1968 será o momento mais marcante de sua emancipação como teórico e militante político: uma verdadeira conversão - ou, como ele próprio prefere dizer, sua estrada para Damasco, seguindo os passos do apóstolo Paulo, figura de particular interesse ao autor pela sua capacidade de renovação e reinvenção de si, ou o seu salto do um para o universal:

A lei é inadequada ao "para todos", pois o para todos é sempre lei estatal, lei de controle das partes, lei particular. O um somente existe na ausência da lei. A universalidade é ligada organicamente à contingência do que nos acontece, que é a superabundância da graça ${ }^{22}$.

Maio de 1968 se insere para Alain Badiou num desses momentos de desarticulação da lei, da ordem, do um. Se a legalidade é sempre predicativa e particular, este momento da história trouxe uma nova possibilidade de conjugação do vazio como transcendência, de reinício, de uma conversão onde o todo se encontra numa possível decomposição de si, ausentando-se e subtraindo-se do todo para uma nova verdade. Declarar um acontecimento é tornar-se filho deste acontecimento ${ }^{23}$. Se os ensinamentos de Althusser sobre o marxismo se enraizaram na psique do jovem estudante de filosofia para todo o sempre (mesmo com divergências, como no caso dos acontecimentos de maio 68), será a partir de seu encontro com o maoísmo que seu ativismo e militância política encontrarão uma nova paternidade: não maio de 68 , mas o outono de 69, com a criação da UCFLM (Union comuniste française leninistemarxiste). Vale dizer que em maio de 68, Badiou já era um comunista, não precisando assim de conversão alguma. Segundo o historiador A. Belden Fields, Badiou foi o fundador da UCFLM enquanto residia e ensinava em Vincennes, cujos objetivos principais eram o de ajudar trabalhadores imigrantes em situação ilegal no país $^{24}$. Tal organização não tinha objetivos eleitoreiros, já que não almejava lançar candidatos, nem se vinculava ao estado totalitário chinês - mesmo que sua afiliação

\footnotetext{
${ }^{22}$ BADIOU, São Paulo, p. 96, 1997

${ }^{23}$ BADIOU, São Paulo, p. 71, 1977

${ }^{24}$ Cf. PLUTH, Alain Badiou, p. 19, 2010
} 
com a obra de Mao fosse latente. Pouco se diferenciava, neste primeiro momento, o marxismo de Badiou e o seu maoísmo.

O que é claro e latente neste momento da vida do filósofo é a urgência entre pensamento e ato, palavra e ação. Sua conversão acontece pelo clamor do tempo, do seu tempo.

Escreve o autor no livro Le siécle:

Eu mesmo passei pela experiência definitiva desta correlação entre transgressão e submissão. Aconteceu em maio de 1968 e durante os anos que se seguiram. Senti que a erradicação da minha existência anterior (aquela de um servo civil e provinciano menor, um pai de família, sem nenhuma outra visão de sustento que não aquela oriunda da escrita de livros), a saída para uma vida submetida, ardentemente submetida, às obrigações de militância em lugares desconhecidos (albergues de trabalhadores, hostels, fábricas, mercados em subúrbios), os confrontos com a polícia, os ataques matinais, os julgamentos - tudo isso tinha sido originado não de uma lúcida decisão, mas a partir de uma forma especial de passividade, de um total abandono àquilo que estava realmente acontecendo ${ }^{25}$.

A partir dos anos 80, Badiou e seus correligionários dão por terminada esta empreitada maoísta, mesmo que um certo senso de militância e ativismo permanecessem sempre vivos na vida e pensamento do autor. Divorcia-se a partir daí a junção política-estado, já que para Badiou, qualquer formalidade estatal sobre a questão não corresponde à real exigência da coisa pública e sua adequação à política. A partir de sua obra L'être et l'évenement a atenção dada à política desdobra-se em outros campos e domínios de produção do homem (ciência, arte e o amor) - ainda que a questão da ontologia é o tema central do livro. Será após esta publicação que o discurso sobre o amor aparecerá com mais frequência nas reflexões, escritos e entrevistas do autor. A política, para o autor, é o inverso do amor, já que este começa onde aquela acaba: a política é um ajustamento, sempre singular, entre a liberdade e a

${ }^{25}$ Cf. BADIOU: The Century, apud PLUTH 2010: p. 21 
igualdade, o amor é a própria incompatibilidade não negociada, mas aceita, ajustada e reconfigurada $^{26}$. O amor e a política, para o autor, encontram-se como uma das condições para o discorrer filosófico, já que ambos versam sobre verdades, mesmo possuindo vetores em sentidos inversos: se o primeiro parte da diferença individual (ou da disjunção) para o universal, no segundo encontramos valores que partem do coletivo para o indivíduo.

No amor, diferentemente da política, não há negociação ou ajustamento desta verdade senão em legislação interna à relação amorosa. Relação esta que lança o Dois do casal numa categoria transitiva, como sujeitos de uma verdade, que representa um desvio em relação à ordem do mundo. A partir do surgimento do Dois, um sujeito do amor é possível. Sujeito não como tradução do individual humano, de uma subjetividade encarnada. É-se sujeito enquanto sujeito de um processo de verdade, em suspensão entre um acontecimento (identidade) e sua unicidade (diferença). Um encontro amoroso é uma ruptura com estado da situação (l'état de la situation). Com Conditions, obra de 1992, as portas do pensamento de Badiou abrem-se formalmente para o tema, inaugurando um percurso de resgate e valorização de um dos temas caros desde o primeiro platonismo. Se o tema até então não tinha recebido a devida atenção e foco do autor, seus seminários, entrevistas e obra perpassam o amor frequente e transversalmente, tal a importância que esta experiência para o autor representa no horizonte da vida de um ser humano.

O amor para Badiou entrelaça-se com a noção de desgoverno, de afiliação e transformação. É o que torna possível, no mundo real das relações, a relação entre a diferença e a verdade pós-acontecimento. Estabelece-se assim uma categoria condicional para o fazer filosófico, um desvio novo à ordem do mundo se inaugura, longe das amarras do ser, entranhado num processo de verdade. Ao dar as mãos ao filósofo Sócrates na busca pela realidade subjetiva e intransferível desta experiência, lembra-nos o autor do processo e procissão das experiências no amor: “(...) aquele

${ }^{26}$ Cf. BADIOU, Éloge de l'amour, p.49-50, 2009 
que segue o caminho da revelação total, deve começar numa tenra idade a ser levado pela beleza dos corpos"27.

Os anos 90 são prolíficos para o autor, com a publicação, por exemplo, de estudos sobre importantes pensadores como Gilles Deleuze (La clameur de l'être, 1997) e Samuel Beckett (Beckett, 1995), ou ainda reformadores do pensamento religioso como o apóstolo Paulo (São Paulo, 1997). A estes se segue uma outra série de obras dedicadas à contemporaneidade do circunstancial político francês ( $D e$ quoi Sarkozy est-il le nom?, de 2007) e mundial (Dialogue sur la politique et la philosophie de notre temps, de 2012).

Em 1999 o filósofo retorna à ENS, como acadêmico convidado, e a partir desta data associa-se a diferentes instituições de ensino de renome internacional como o Collège International de Philosophie e o European Graduate School em Saas-Fee, Suíça, e leciona em seminários de verão. Seu campo de ação e pensamento chega aos palcos com a publicação em 1998 da peça Ahmed le Subtil. Desde a última década seus trabalhos são traduzidos para outros idiomas, despertando interesse em diversos campos do pensamento e de ação sócio-política. É frequentemente convidado como colunista em jornais filosóficos americanos e ingleses como o Lacanian Ink, New Left Review e Radical Philosophy.

Em 2009, é publicado o livro L'éloge de l'amour, a partir de sua entrevista concedida a Nicolas Truong, como parte dos eventos (Théâtre des idées) do Festival de Avignon, onde a questão do amor e sua relação com a filosofia, vida prática, teatro e artes, recebem um tratamento direto e inconfidencial. A fidelidade das transposições da fala para escrita trazem à tona um tom personalista, íntimo, irrepetível. A história da filosofia conhece poucos relatos de um autor que se abra tão livremente à questão. A sua fidelidade ao amor se atesta quando diz:

(...) o inimigo principal do meu amor, aquele que eu devo vencer, não é o outro, sou eu mesmo, o "eu" que quer a identidade

\footnotetext{
${ }^{27}$ Cf. BADIOU, Alain, em entrevista a Miguel Abreu Gallery, NYC, em 13 de nov. de 2007,
} http://www.lacan.com/symptom9_articles/badiou19.html. 
contra a diferença, que quer impor o seu mundo contra o mundo filtrado e reconstituído no prisma da diferença ${ }^{28}$.

O amor deve se separar do que não é amor, da noção de qualquer discurso totalitário ou hierárquico entre o corpo e o pensamento:

(...) o pensamento e o corpo são de alguma maneira indiscerníveis. Os dois são expostos um ao outro de tal maneira que não se pode dizer "Isso aqui é um corpo" ou "Isso aqui é um pensamento". Existe uma mistura entre os dois, uma apreensão do corpo pela língua, exatamente como quando dizemos a alguém "eu te amo" $(\ldots)^{29}$.

O objetivo maior de Badiou parece ser o esforço de se identificar e expor a profundidade e potência de toda e qualquer inovação, indo além da mera identificação do mesmo - ou da mera subtração do particular na busca de uma verdade universal. A filosofia para o autor é algo vivo e orgânico, que se busca e se reinventa ao buscar, nas condições que lhe são pertinentes, sua própria causa e razão de ser: construção e reinvenção de si mesma. Citando Arthur Rimbaud, nos lembra Badiou em L'éloge de l'amour, da irreverente proposta do jovem poeta: "O amor é para se reinventar, sabese bem!" 30 .

E contra qualquer segurança ou zona de conforto do pensamento, sua visão do amor vem ao nosso auxílio, já que em fina sintonia com o ritmo e fluxo das transformações do mundo contemporâneo: "Isso (o amor) não pode ser uma defensiva pela simples conservação das coisas. O mundo está, efetivamente, cheio de novidades e o amor deve ele também ser pego por estas inovações. É preciso reinventar o risco e a aventura, contra a segurança e o conforto" 31 .

\footnotetext{
${ }^{27}$ Cf. BADIOU, Alain, L'éloge de l'amour, p.54, respectivamente, 2009

${ }^{29}$ Cf. BADIOU, Alain, L'éloge de l'amour, p72-3, 2009

${ }^{30}$ Cf. RIMBAUD apud BADIOU 2009: p.8

${ }^{31}$ Cf. BADIOU, Alain, L'éloge de l'amour, p. 17, 2009
} 


\section{Alain Badiou e a Filosofia}

Para Peter Hallward, Alain Badiou faz parte desta longa lista de escritores franceses aparentados à noção de populismo na filosofia, e cujas origens se encontram em Descartes e até em Voltaire, passando por Rousseau, Bergson e Sartre - o autor também inclui Foucault e Deleuze na lista. Todos estes escritores, segundo Hallward, possuem uma escrita de retórica sensualista e persuasiva, direcionada a um público no limite do establishment - à borda da sociedade ${ }^{32}$. Badiou se lança à escrita filosófica em francês usufruindo de sua clareza sintática, sua profundidade semântica, ordem lógica e poder de abstração. Se a língua é o solo pátrio de um autor, o terreno filosófico de Badiou, em contrapartida, será estéril e vazio, desprovido de pátria - e de língua. Para o autor, assim como para o seu mestre Louis Althusser, a filosofia deve ser não-objetal, atemática, apartidária e livre das amarras identitárias - logo, sem história e caráter, nacionalidade e sexo, suspensa na extemporaneidade do pensamento e do acontecimento ao qual se refere.

A filosofia de Badiou se formula ao redor da possibilidade do aparecimento de uma verdade - e não na montagem retórica de operações e quebra-cabeças da linguagem. Desde Platão que a questão aparece de maneira insistente (o thauma: o espanto, o surpreender-se, o maravilhar-se) já que é através de um acontecimento, ou quebra na opinião, que a filosofia se sedimenta e encontra seu campo de ação. Todo o conceito de filosofia para Badiou é inspirado nesta simples e poderosa ideia de que qualquer existência pode um dia vir a ser transfigurada pelo que nela aconteça, afiliando-se a partir deste processo numa outra vertente que não a sua de partida. $O$ acontecimento é a suspensão de toda re-apresentação. O perserverar-se nele é também conversão ao infinito possível de uma verdade. Cabe à filosofia a tarefa de identificar e amarrar estes processos de verdade - ou procedimentos genéricos, no vocabulário do autor - nas ciências, nas artes, na política ou no amor.

Toda e qualquer evocação de um senso comunitário de costume, tradição ou cultura, para Badiou, caminha em direção contrária ao surgimento de uma nova

\footnotetext{
${ }^{31}$ Cf. HALLWARD, Badiou, a subject to truth, p. 11, 2003
} 
verdade. A filosofia verdadeira é avessa a esse sentido por não possuir amarras, não podendo residir nas zonas de conforto da vida e do pensamento. A partir destes pressupostos, quais as resistências e consequências de tais novos procedimentos de verdade perante um mundo imerso num fluxo incessante que resiste e é indiferente às ideias destes novos procedimentos de verdade? Como os que afirmam tais processos podem manter-se fiéis a estes sem serem engolidos pelo excesso de fluxo ou pelas amarras da identidade? O operacional da vida sistematiza, enquadra, aprisiona o homem. A verdade filosófica identifica aquilo que o liberta, o expande, convidando-o à transformação de si. A filosofia é o campo de pensamento que se outorga o poder de enunciar que as verdades existem, e que tais procedimentos são compossíveis no horizonte do existir junto com aquilo que preexiste - e coexiste, enfim.

\subsection{A filosofia e a verdade}

Para Badiou, não há verdade fora do campo da presença. Para que tal categoria operatória de formulação de verdade sobre a vida exista, é preciso criar um campo ativo e vazio, no pensamento, para abrigá-la. O vazio aqui em questão é o próprio fazer filosófico na suspensão temporal da reflexão, equacionado em ficção do saber, ativo na recriação poética do mundo. Será neste espaço intermediário que a filosofia agarra e amarra a verdade, subtraindo-a do plano da experiência.

Um ato, um salto do pensamento para a existência: caberá à filosofia o fazer existir da verdade. “A verdade é, há verdades!”33. O pensamento filosófico ganha sua unidade e consistência através desta declaração. Badiou crê que a filosofia possui a intensidade de um ato de amor, só que sem amado ou amante, como um poema que se cria para além da linguagem, na temporalidade entendida na suspensão do tempo corrente. Um presente temporal que se dilata, que se identifica, promove e opera pela eleição de suas verdades. Assim diz o autor:

\footnotetext{
${ }^{32}$ Cf. BADIOU, Conditions, p. 79, 1992
} 
A filosofia se estabelece através de condições que são os tipos de procedimentos de verdade, ou procedimentos genéricos. Esses tipos são a ciência (mais precisamente a matemática), a arte (mais precisamente o poema), a política (mais precisamente a política em interioridade, ou política de emancipação) e o amor (mais precisamente o procedimento que torna verdade a disjunção das posições sexuadas) ${ }^{34}$.

Há uma fina sintonia entre a prática filosófica e seu tempo real, já que é ela quem nomeia, através de si mesma, o sistema discursivo das condições. Cabe à filosofia separar o sempre do tempo, o perene do passageiro; o eterno há que ser extraído do temporal das quatro condições e instaurado na recomposição de verdades. A filosofia é a prática que extrai da repetição enfadonha dos dias o inusitado do humano, sua inserção na reinvenção de um possível universal contemporâneo, sintonizado com as práticas da atualidade.

A filosofia caminha em direção contrária à religião. Se esta dispõe da continuidade entre as verdades e postulados na circulação temporal do sentido, aquela identifica a nova face de uma nova verdade, subtrai dela sua compossibilidade com o indizível, com o indiscernível, com o inominável e com o genérico ${ }^{35}$. Este ato é em si improdutivo, segundo Badiou, já que ele mesmo não é, em si, capaz de produzir uma verdade. A filosofia é o instrumento para o discernimento do aparecimento desta verdade, subtraída de uma consideração objetal, aberto às manifestações que transitam nesta nova formulação. Ele assim relata em Segundo manifesto por la filosofia:

Coisas que são imediatamente universais no seguinte sentido: para um outro mundo, para uma outra cultura, para outros indivíduos que o mundo, para a cultura ou os indivíduos que participaram de seu surgimento e desenvolvimento; a "coisa" em questão possui um valor apropriável, um tipo de resistência própria,

\footnotetext{
${ }^{34}$ Cf. BADIOU, Conditions, p. 79

${ }^{35}$ Cf. BADIOU, Conditions, p. 80
} 
a despeito da estranheza dos corpos e linguagens que compõem a sua materialidade ${ }^{36}$.

Há um transmundanismo que edifica esta questão, já que a materialidade das coisas e corpos, para o autor, vale para todos os outros, insere-se na qualificação de verdade temporal do homem e de suas condições. Há uma virtualidade genérica que se estabelece neste processo, valendo para o todo da humanidade. Para Badiou, a coisa é cercada de cultura, de materialidades humanas específicas, mas o que pode daí emergir, em contrapartida, é um inaugural aristocrático de verdade, um processo de criação de uma estranheza perante o mundo, reciclável na dinâmica do humano. $\mathrm{O}$ tempo e o espaço se esvaziam neste caso, criam um solo sem apoio para que a filosofia identifique e contextualize esta criação - que pode se refletir em outros processos individuais alijados desta coisa. A coisa é antidemocrática. É a exceção ao materialismo democrático. Seria sofística se lhe fizesse objeção, resistência. A filosofia não pode viver sem o seu outro, o sofista. Sua morte é ali declarada. Graças ao sofista, segundo Badiou, temos a noção de que a verdade é vazia ${ }^{37}$, flutuante, volátil e alada. A filosofia não pode viver sem identificar este vazio, já que seria dogmático o risco do estabelecimento monocórdio do um na verdade.

Badiou identifica princípios: na matemática, na música, no amor, nas revoluções. A filosofia fabrica princípios a partir destes princípios, formula a constrição da exceção que brota da verdade. A filosofia é o salvo-conduto da verdade para além da opinião corriqueira, dos jogos de linguagem e da desconstrução ${ }^{38}$. $\mathrm{O}$ mesmo do mundo é capturado pela opinião, reflete-se na prática do questionamento transmundano, aprisionado pelas práticas democráticas do mesmo.

A filosofia é um exercício contra a história do ontem e do amanhã, contra a historicidade de sua verdade. E a verdade, para Badiou, é emancipatória, libertadora do homem dos vínculos da liberdade democrática aceita como norma, exercício da lei. A filosofia é a identificação desta comunicação do mundo com o supermundo,

\footnotetext{
${ }^{36}$ Cf. BADIOU, Segundo manifesto por la Filosofía, p.26, 2010

${ }^{37}$ Cf. BADIOU, Conditions, p.75, 1992

${ }^{38}$ Cf. BADIOU, Segundo manifesto por la Filosofía, p.30, 2010
} 
com o um do humano que está no devir, no virtual incriado e vindouro deste homem que ainda não é.

O autor a vê aparecer num sentido obreiro, laborioso do humano. Não é um pensamento que busca a expressão de si, ciclicamente, sofisticamente, mas sim aquele que busca o processo, a disciplina, a produção - e "não o consentimento indolente de um mundo „39. Há no filósofo a tarefa de identificar e ativar a solda das verdades no transversal dos dias, já que a filosofia nada apresenta - apenas reconhece, elege. Possui um valor de disciplina, mas sem objeto próprio, que recebe de suas condições os objetos subtrativos a partir de uma situação ou de uma lógica de uma situação. Mas o que acontece ao que está fora do alcance das condições?

O mundo do real supervisiona as diferenças estabelecidas, coordena o domínio e o controle dos privilégios herdados da tradição e das opiniões. Toda a proclamação de verdade ou de subjetividade ${ }^{40}$ em Badiou seria como uma ruptura na economia das relações do mundo, sustentada pela força de sua inventiva convicção de ser uma singularidade sem especificidade relacional imediata.

Há um tecido que liga o todo ao homem, mas o sujeito que se instaura nas condições está fora das amarras da norma, da moral, do genérico. A filosofia reconhece, na sua proclamação de verdade, a independência perante a identidade, o homem desprovido de substância. O sujeito contemporâneo é vazio, clivado, asubstancial, irreflexivo ${ }^{41}$. Ele é também a-social, anti-psicológico, anti-normativo e $a$-cultural. O fim e o início de um homem que está no porvir, na sua reinvenção. Como esse homem se estrutura e define, são também as condições para que o real se re-estruture e re-defina.

Badiou afina o seu discurso e análise filosófica num círculo de transversalidades com a história do pensamento ocidental, com as matemáticas póscantorianas, com a psicanálise, com a arte contemporânea e com a política. Mesmo

\footnotetext{
${ }^{39}$ Cf. BADIOU, Segundo manifesto por la Filosofía, p.30, 2010

${ }^{40}$ Subjetividade, para Badiou, é a experiência ou identificação com um evento, uma conversão e militância à causa, cuja identidade reside incondicionalmente nesta fidelização a uma das condições (na política, no amor, na ciência, na arte).

${ }^{41}$ Cf. BADIOU, $O$ ser e o evento, p.12, 1996
} 
que a filosofia não coincida com estas zonas e momentos do pensamento, ela é ainda assim a responsável pela visão da totalidade destes campos, o elemento agregador da sua compossibilidade ${ }^{42}$.

Se não há na sua filosofia uma função fundadora, há sempre uma consagração dos campos da verdade, e do infinito que se edifica na revolução, paixão, invenção e criação (os modos de expressão do devir das condições, correspondendo, respectivamente, à política, amor, ciência e à arte). $\mathrm{O}$ homem de verdade em Badiou é subtraído do outro, já que imerso na sua convicção de verdade, no extraordinário de sua diferença.

Nas palavras de Badiou: “O pensamento do genérico supõe a completa travessia das categorias do ser (múltiplo, vazio, natural, infinito...) e do evento (ultraum, indecidível, intervenção, fidelidade...)" ${ }^{43}$. A política é o que há de mais genérico para o autor, já que ela se funda na proclamação de seus resultados ao coletivo, bem como na composição local de seu sujeito, que se reflete num espelho universal do humano. Toda noção de coletivo para Badiou é universalizante.

Se a identidade oscila entre as condições de tudo aquilo que é representável pelo saber social (técnico, matemático, sexual, artístico), o que subjaz ao ultra-um possível dos genéricos (a revolução, o encontro amoroso, o evento artístico...) é a diferença e eclosão pelo acontecimento de um outro processo estruturante, fundador. A ciência, a arte e amor, mesmo ao dirigem-se ao todo, são verdades aristocráticas, alheias ao regime dos enunciados à comunidade. Seus charmes e processos se refletem na assunção do Dois (no caso do amor), ou ainda na exacerbação do um (a arte não precisa de ninguém além do um para ser arte) ${ }^{44}$.

O sujeito do amor só se sustenta localmente, na eclosão do acontecimento do seu procedimento genérico, mesmo que sua semântica se alinhe com valores universais. Ele se efetiva no seu há presencial, na sua capacidade operativa e participativa. A filosofia tem de se submeter a tudo aquilo que não pode explicar no

\footnotetext{
${ }^{42}$ Cf. BADIOU, O ser e o evento, p.13, 1996

${ }^{43}$ Idem, p.22, 1996

${ }^{44}$ Cf. BADIOU, Compêndio de metapolítica, p. 166, 1998
} 
amor: encontro, acontecimento, verdade. Não há acontecimento natural ou neutro no amor.

A filosofia para o autor trata daquilo que, como no amor, escapa do global, do critério, remetendo-se àquilo que é $a$-histórico e que escapa às contrações das situações naturais. O que faz o real, de certa maneira, reinventar sua consistência e perserverança. A filosofia deveria ter, ainda assim, a força do ato de um amor avassalador - só que sem objeto e desejo.

A filosofia deveria ser pensada como uma ficção do saber ou da arte - daí imitar o mathema e a poesia, respectivamente -, só que sem o formalismo da matemática ou o materialismo da obra de arte. Uma ficção científica, mas sem o empirismo técnico da ciência. A filosofia deveria ser direcionada para ninguém e para todos, de tal maneira que todos possam ser atingidos pela força da eclosão do acontecimento da verdade (como uma estratégia política só que sem o constrangimento do partidarismo e da organização governamental) ${ }^{45}$, ou de uma transformação tão radical como a conversão religiosa - só que a partir de parâmetros racionais. A grande diferença, para o autor, está no fato que a filosofia não é um conhecimento - ou conhecimento de conhecimento -, mas sim a força de um ato, um gesto para revirar a sorte dos dias, do homem, da mentira existente em toda opinião tida como verdadeira - como fez Sócrates ao se dirigir à juventude na Atenas clássica $^{46}$.

A filosofia é a reorganização possível do todo da experiência, a atualização da coisa pública, científica e artística: a corrupção do normativo, do prescritivo. Um dar cambalhotas no status quo da verdade. E a verdade, para Badiou, é o que desperta no espírito o valor de liberdade na cultura, um abrir de olhos ao direito assistido e garantido de se poder repelir o que há de dominante e isonômico no mundo. Somente uma verdade pode abrir o um do super-mundo e do real de um mundo que está por vir.

\footnotetext{
${ }^{45} \mathrm{Cf}$. BADIOU, Infinite thought - truth and the return to Philosophy, p.166, 2004

${ }^{46} \mathrm{Cf}$. BADIOU, Philosophy as creative repetition, em http://www.lacan.com/badrepeat.html
} 
Não basta colher o momento: "A estratégia de carpe diem é uma reação a um mundo esvaziado de valores que finge ser duradouro" - nas palavras de Bauman ${ }^{47}$. Embebido do verdadeiro, o homem badiouniano é aquele que pode finalmente despertar ao fato de que, mesmo que ninguém seja realmente livre, ninguém está alijado à possibilidade de acesso à criação da verdade ${ }^{48}$. Para o autor, este processo se dá como uma reconstrução de contexto, de significado, a partir da ruptura de um acontecimento, como uma disjunção na ordem do ser da verdade, já que, para Badiou, “há, sem dúvida, o ser da verdade, que não é a verdade, que é, justamente, seu ser" 49.

O cartão de visita e embarque para sua obra está relacionado à questão do ser, bem como às tentativas de categorização da noção de sujeito. Para o autor, o ato inaugural aristotélico ao criar a noção de ser-enquanto-ser, ancorado no campo livre das indeterminações, nos remete à noção de um ser puro, alheio às considerações de verdade a partir da identidade e diferença. Aristóteles pensa o ser primeiro livre das amarras das contingências empíricas, o que para Badiou só pode ser sistematizado a partir da matemática. Ser e sujeito se articulam ao redor das condições, dependentes e relacionadas ao acontecimento dos procedimentos genéricos, na suspensão do situacional mundano - o-ser-enquanto-não-ser ${ }^{50}$. Assim, para chegarmos ao ser e às noções de subjetividade no amor, a partir do acontecimento, algumas considerações adicionais fazem-se necessárias.

\section{Ontologia e a matemática}

Para o autor, a matemática ocupa posição sui generis em relação ao pensamento do homem, por não se encontrar representável no campo da experiência (no mundo da physis, mais precisamente), e por se constituir de uma operacionalidade de elementos indivisíveis e absolutos, incorruptíveis - os números. Trazer as relações

\footnotetext{
${ }^{47}$ Cf. BAUMAN, Identidade, p.59, 2005

${ }^{48}$ Cf. BADIOU, Segundo manifiesto por la filosofia, p. 30, 2010

${ }^{49}$ Cf. BADIOU, O ser e o evento, p.279, 1996

${ }^{50}$ Cf. BADIOU, O ser e o evento, p. 20, 1996
} 
matemáticas para a experiência seria virótico, infectável pelo corruptível e divisível dos corpos sensíveis, já que nos forçaria a pensar as relações da imanência de maneira indivisível e atômica. Qualquer operação matemática na experiência a infectaria com predicados alheios à sua raison d'être (como a temporalidade e a corruptibilidade), e o inverso causaria o mesmo estranhamento já que tais predicados corruptíveis são alheios ao perene do inteligível, à imobilidade do ideário que lhe é pertinente ${ }^{51}$.

O objeto da matemática é sempre potência, mas inexistente em qualquer parte que seja, no real da experiência, que é ato. Este aspecto trans-situacional da matemática faz com que Badiou a pense num estado de suspensão, entre a transcendência do não-físico e a imanência da representação. Nas palavras do autor: "Digamos que a objetividade da matemática é um pseudo-ser, pendente entre o ato puro, cujo supremo é Deus, e as substâncias sensíveis, ou coisas realmente existentes. A matemática não é nem física nem metafísica" ${ }^{52}$.

Para Badiou, somente a matemática pode ser pensada livremente, fora de qualquer noção de impredicabilidade. Um pseudo-ser, ou algo como se fosse-um-ser. Para Badiou, a matemática é o indeterminado entre os mundos, cabendo a ela, por si e partir de si, ser a porta-voz, por excelência, a poder falar da ontologia ou sobre o ser das verdades.

A partir de $O$ ser e o evento (1988), estrutura-se no pensamento do autor o axioma que relaciona a noção de unidade à ideia de o ser apresentar-se sempre na sua multiplicidade, ou multiplamente informado. Este fato vem a formalizar que o um não é. Conclui o autor que toda noção de unidade é incompatível com a noção de experiência, já que abstraída de toda presença ou informação unitária do que quer que seja. O um é, assim, não-recíproco à experiência - pensado nas condições de Verdade da teologia, no absoluto, ou no ideário da metafísica. Será na noção de múltiplo, então, que se estruturará a apresentação do ser no real. A partir de tal pressuposto, o da disjunção entre ser e unidade, deduz-se a reciprocidade entre o ser e a multiplicidade, e para que se considere a apresentação de um múltiplo na experiência,

\footnotetext{
${ }^{51} \mathrm{e}^{51}$ Cf. BADIOU, Breve tratado de ontologia transitória, p. 42-43, 1998
} 
há que se considerar o pressuposto da inexistência de um ser metafísico e divino como regente supremo das coisas e relações.

Tudo é sempre informado de maneira plural, polissêmica e multi-informada. Resulta, em consequência, o fato que o um só nos é permitido aparecer como estrutura daquilo que aparece, não como ontologia ou categoria. Isso será o que o autor chamará de o contar-por-um (le-compte-pour-un). Todo o nosso aparato empírico se organiza através de uma formatação sensorial multiplamente informada. Para que haja um evento, um fato, uma situação, é preciso que tenhamos o efeito de uma contagem, do um estruturado a partir de um múltiplo sensível, daí concluirmos que não há, na experiência, a possibilidade de uma apresentação do ser puro, impredicado. Conclui então o autor:

(...) que a situação ontológica seja a apresentação da apresentação. Se este for o caso, de fato, permanece possível que seja do ser-enquanto-ser que se trata esta situação, pois nenhum acesso ao ser se oferece a nós afora as apresentações. Quando menos, uma situação cujo múltiplo apresentativo é o da própria apresentação que pode constituir o lugar de onde se apreende todo acesso possível ao ser. $^{53}$

Para que entendamos o significado de uma apresentação da apresentação é preciso pensar o ser e seus predicados como homonímias do múltiplo. Toda situação é estruturada, organizada pela lei do contar-por-um, pensado aqui como um sistema de condições que nos deixa reconhecer a condição do múltiplo como múltiplo. A matemática em Badiou é nada mais que uma apresentação (consistente) de um puro (inconsistente) múltiplo ${ }^{54}$. A verdade nasce naquilo que o múltiplo tem de inconsistente: no indiscernível do acontecimento, na ruptura do consistente da ontologia do mesmo, o que rompe com o código do ser sobre o sendo ${ }^{55}$.

Conclui Badiou em O ser e o evento (1996):

\footnotetext{
${ }^{53}$ Cf. BADIOU, Being and Event, p.27-8, 2005

${ }^{54}$ Cf. HALLWARD, Badiou a subject to truth, p. 90, 2003

${ }^{54}$ Idem
} 
Disto se infere a seguinte tese: se uma ontologia é possível, isto é, uma apresentação da apresentação, ela é situação do múltiplo puro "em si”. (...) o que é apresentado na situação ontológica é o múltiplo, sem outro predicado que sua multiplicidade. A ontologia, à medida que ela exista, será necessariamente ciência do múltiplo enquanto múltiplo. ${ }^{56}$

Se toda a experiência é estruturada multiplamente, somente uma teoria como a de Cantor (dos conjuntos) pode dar conta, na imanência, da questão da multiplicidade - ou dos múltiplos - sem determinações externas. Para Badiou, todo elemento de um conjunto é, ele também, um conjunto (ou um múltiplo de múltiplo, sem referenciais externos ou noção de unidade - como na ideia do um). Conclui-se assim que um sentido último (ou primeiro) das coisas inexista, mesmo que numa análise superficial da experiência tenhamos sempre a noção de estrutura e unidade em mente. A razão nos condiciona ao um.

Peter Hallward vê nesta ausência do um teológico em Badiou uma abertura ao infinito no próprio humano, ou ainda no banal da experiência, no vazio que se determina como genérico do todo apresentável ${ }^{57}$. O que há é o vazio, ou o pensamento e a linguagem como potências e amarras ao todo. $\mathrm{Ou}$, ainda, a infinidade de conjuntos, num infinito inter-relacional cujo limite é a noção de conjunto-detodos-os-conjuntos. Para o autor, somente a matemática pode agarrar o inconjecturável do ser, o que escapa a toda presença e a toda experiência:

O nosso intuito é estabelecer a tese metaontológica ${ }^{58}$ de que as matemáticas são a historicidade do discurso do ser-enquanto-ser. E o intuito desse intuito é remeter à filosofia para a articulação pensável de dois discursos (e práticas) que não são ela: a matemática, a ciência do ser, e as doutrinas intervenientes do

\footnotetext{
${ }^{56}$ Cf. BADIOU, O ser e evento, p. 33, 1996

${ }^{57}$ Cf. HALLWARD, Badiou a subject to truth, p.7 e 94, 2003

58 Entenda-se aqui metaontologia como hipótese não para uma formulação da matemática como ontologia, mas sim como uma superfície de sentido e linguagem onde se pode desenvolver e ancorar o discurso da ontologia - mais precisamente, no discurso e pensamento badiouniano, na teoria dos conjuntos de Cantor.
} 
acontecimento, o qual, precisamente, designa "o-que-não-é-o-serenquanto-ser.",59

A partir de tal premissa, articula-se o discurso filosófico não como discurso de interpretação do real pela matemática, ou de uma estruturação de uma filosofia da matemática, mas sim o que se pode, através dela e por ela, fazer manifestar uma essência ontológica no evento das verdades dos procedimentos genéricos:

(...) A matemática é citada aqui para que se torne manifesta sua essência ontológica. (...) Pois o que é esperado dessa operação é menos um saber das matemáticas do que a determinação do ponto em que o dizer do ser advém, em excesso temporal sobre si mesmo, como uma verdade, sempre artística, política ou amorosa. ${ }^{60}$

Se a matemática para Badiou é estruturada como ontologia, a questão do ser, ainda assim, escapa à filosofia. Não será ela (a filosofia) a se ocupar das questões do ser, mas só e somente a matemática, já que para o autor o operacional da matemática é já uma ontologia discursiva, que através da teoria dos conjuntos de Cantor consegue resolver o problema da identificação e descrição da multiplicidade inconsistente do real.

Segundo Badiou, é uma imposição de nosso tempo o uso da matemática na fundamentação para que pensemos o ser no sujeito e na verdade. Só assim será univocamente acessível, com valor de universalidade, a manifestação genérica do acontecimento, encadeada pelo vazio da verdade matemática no interior do acontecimento - o que veremos a seguir.

\section{Acontecimento (L'évenement)}

As quatro condições da fillosofia em Badiou se articulam ao redor da possibilidade de um acontecimento. Mesmo que as quatro verdades selecionadas pelo

\footnotetext{
${ }^{59}$ Cf. BADIOU, $O$ ser e o evento, p. 20,1996

${ }^{60}$ Cf. BADIOU, O ser e o evento, p. 23, 1996
} 
autor não sejam as únicas manifestações do homem dignas de análise, são ainda assim aquelas com pretensão universal, cujos valores globais causariam ressonância além daquelas propostas por outros sistemas como a teologia, a psicologia, o trabalho ou o direito ${ }^{61}$.

Badiou concentra-se na identificação dos processos articulados ao redor e a partir da eclosão de um acontecimento, estabelecendo e edificando, pelo uso da razão - e pela sua subjetividade analítica - julgamentos e postulados sobre o aparecimento de uma nova verdade. A verdade pós-acontecimento é o que pavimenta o caminho para um pensamento atualizado - e consequentemente histórico - da filosofia sobre as práticas discursivas em questão. É o transcendental do humano que se transcodifica pelo acolhimento filosófico da eleição da erupção de uma nova verdade. É quando o pensamento, o homem, a ação e o tempo estão finalmente irmanados na imanência do evento, na identificação ontológica do múltiplo de exceção no decorrente da verdade aceita. Se toda situação é estruturada pela repetição dos fatos, o acontecimento é o sem precedente do extraordinário e do inusitado, o que nos evidencia o genuíno e o impredicável - até então - da verdade.

Peter Hallward propõe que nada pode realmente provar a existência e a concretude de um acontecimento $^{62}$. A questão é sempre sobre o conjecturável, aberto às especulações, suspenso, num primeiro momento, entre o lugar comum da opinião e do mesmo - e às variantes possíveis da ruptura. A constatação real do fato só pode ser pensada, para Hallward, a partir do aparecimento de sujeitos, aqui pensados como identidades relacionadas e construídas pela contingência perpendicular ao evento.

O acontecimento abre uma brecha temporal na história (da humanidade ou de indivíduos, como no caso do amor), o que faz o tempo transcender-se, na construção de uma subjetividade futura e anterior - futura por depender da fidelização de sujeitos; anterior por ser condicionada e articulada a tudo aquilo que o acontecimento possui de indizível, inconceituável e incomensurável - o seu vazio.

\footnotetext{
${ }^{61}$ Cf. BADIOU, Alain, Second manifeste pour la philosophie, p.149, 2009

${ }^{62}$ Cf. HALLWARD, Peter, Badiou a subject to truth, p. 115, 2004
} 
Hallward conclui que o vazio do acontecimento é o que o relaciona ao genérico do humano, a uma nova noção de humanidade que volta a se expor e repor no presencial histórico do mesmo do homem a sua nova ingerência na diferença - a recriação de $\mathrm{si}^{63}$.

Badiou, no seu livro São Paulo, nos convida à reflexão do homônimo apóstolo sobre os efeitos do advento do Cristo. Para o apóstolo, segundo Badiou, o Cristo inaugura uma brecha no processo de verdade, o que convida o crente a ir além do acontecimento do próprio Cristo, bem como da relação mestre-discípulo: "A ressurreição é, para Paulo, aquilo a partir do que o centro de gravidade da vida está na vida, pois anteriormente, sendo colocado na lei, ele organizava a subsunção pela morte." ${ }^{\text {"64 }}$ Abre-se aí uma brecha para um novo tipo de identificação e homem, de uma nova via para a subjetividade que se alinha a um processo de verdade na sua recomposição - e não servidão. Se a lei é o que alinha o homem ao servir, o advento cristão é o que o convida ao pensar, a uma reelaboração de escrita e de fala sobre a verdade. "Trata-se de uma comunidade de destino no momento que temos de nos tornar uma nova criatura ${ }^{65,}$.

Ocorre assim, a partir do Cristo, uma ruptura no ordinário do tempo, já que uma nova noção - a de eternidade - se instaura na verdade da palavra do ensinamento. $\mathrm{O}$ acontecimento e a verdade, aqui, para Badiou, dão uma sobrevida ao animal e ao mortal do homem.

O acontecimento não possui partes, não é fragmentável. Nas situações neutrais e naturais não há nada além de fatos, e a distinção entre aquilo que é fato e acontecimento reside nos efeitos globais e históricos do evento, mesmo que os seus critérios de identificação e eleição sejam locais. O evento está sempre amarrado a um sítio $^{66}$ presencial e particular, a uma historicidade de uma situação ${ }^{67}$. Todo

\footnotetext{
${ }^{63}$ Cf. HALLWARD, Peter, Badiou a subject to truth, p. 117, 2004

${ }^{64}$ Cf. BADIOU, São Paulo, p. 74, 2009

${ }^{65}$ Cf. BADIOU, São Paulo, p. 75, 2009

${ }^{66}$ A noção de sítio é apresentada como o tipo local da multiplicidade concernida de um acontecimento, o sítio é uma condição de ser do evento, um múltiplo anormal na borda do vazio do acontecimento.

${ }^{67}$ Cf. BADIOU, O ser e o Evento, p. 147, 1996
} 
acontecimento possui um sítio identificável, temporal e histórico, encontrado nas suas raízes e amarras perante a verdade.

Toda verdade, para o autor, se dá no pós-eventual: é quando o múltiplo se reorganiza, redefine o seu discurso perante o real da imanência. O ser aqui se quebra, se subtrai da verdade, se perde ao se confrontar com o novo espaço vazio aberto por esta ruptura. "O dizível do ser é disjunto do dizível da verdade", conclui Badiou em $O$ ser $e$ o evento $^{68}$. Cabe à filosofia preencher esta ausência de ser do acontecimento, construir aquilo que há de nomeável e autêntico do interno de sua estrutura de verdade. Estabelece-se a partir deste processo um novo nós - já que a noção de indivíduo se dissipa nesta situação - imortal, eterno, indiferente e alheio à natureza perecível do humano.

Bruno Besana escreve a respeito:

Consequentemente, o aparecimento de uma verdade não só exige um primeiro acontecimento e momento de de-cisão, mas pede também um infinito de personificações, uma infinidade de novos atos e ou questões que de-cidem (sem prova) que cada ponto da situação pode ser subtraído do processo atual de conhecimento, e ser entendido de acordo com o aparecimento da verdade. ${ }^{69}$

Besana questiona ainda os critérios referentes à eleição desta categoria de evento, quais procedimentos deveria a filosofia - e o filósofo - adotar na concretização deste ritual de verdade. Vida e pensamento filosóficos devem ser unidos num só conceito e operação, já que ao separarmos uma do outro, perdemos o acesso à questão da verdade e a raison d'être da filosofia de Badiou.

Na introdução do livro Alain Badiou - Key Concepts, os autores A. J. Bartlett e Justin Clemens recordam o elo entre a filosofia de Badiou e a de Platão. Para os autores, ambos foram capazes de ver e rever seus conceitos e pensamentos, numa quebra constante de suas premissas, na busca incessante de respostas à pergunta

\footnotetext{
${ }^{68}$ Cf. BADIOU, O ser e o Evento, p. 279, 1996

${ }^{69}$ Cf. BRESSANA, Alain Badiou key concepts, p. 42, 2010
} 
“como devemos viver?" "70. A dialeticidade da dialética platônica, em Badiou, referese a este processo de revisão e atualização da Ideia $^{71}$ na imanência, abrindo novas pontes e perspectivas às questões universais da verdade, que, através do acontecimento, buscam revalidar o poder da exceção e do extraordinário do condicional da filosofia.

\subsection{Lacan, um acontecimento no amor}

Quando falamos em acontecimento no amor, pensamos no encontro entre casais, na consagração deste pacto de diferenças através de enunciados como "eu te amo", "nós nos amamos", "você me ama" etc. Estamos sempre no campo do individual e do particular, na erupção do dois na sua explícita horizontalidade. $\mathrm{O}$ amor se efetiva pelo excesso e contágio do um sobre o outro um que é o outro. Mas há que se pensar também, segundo Badiou, o que pode ocorrer na alteração universal do procedimento genérico do amor através de autores e sistemas de pensamento que contribuiriam ativamente no estabelecimento de novos horizontes conceituais na verdade da questão.

Platão, certamente, inaugura uma nova grafia do amor no Banquete, ao confrontar encômios tão díspares - e dissonantes - quanto possíveis para a sua época, abrindo bifurcações e transversalidades na verdade de eros. Com Platão, vemos a dialogicidade entre o universal (no encômio de Sócrates) e os particulares propostos pelos outros encomiastas, trazendo para o irremediável da diferença, da incompatibilidade e da disjunção, a necessidade de um novo espaço discursivo sobre a questão - em especial no encômio de Alcibíades. Mas se há para Badiou um outro vazio inaugural e conceitual que se abre num passado recente sobre o tema, este vazio-ativo refere-se à obra e pensamento de Jacques Lacan, seguramente a maior

\footnotetext{
${ }^{70}$ Cf. BARTLETT e CLEMENS, Alain Badiou key concepts, p.3, 2010

${ }^{71}$ Ideia (eidos) em Platão equivale à noção de verdade em Badiou
} 
influência nas análises do autor sobre a questão ${ }^{72}$. Lacan seria um real acontecimento, para Badiou, no universal genérico do amor, mesmo que o tema não seja um ponto central de sua obra e pensamento.

As alusões feitas pelo psicanalista atravessam perpendicularmente a verdade do amor, ainda que a psicanálise possa ser, por vezes, considerada como um aparato instrumental específico da opinião que se reclina sobre práticas institucionais específicas. E não seria isso, talvez - questiona Badiou - o trabalho de um filósofo, que ao levar em conta o estrutural da opinião sobre uma verdade, contribui com enxertos e considerações no vazio do espaço da questão na procura de abrigo de novas compossibilidades $?^{73}$

Há algo de inusitado nesta eleição de Lacan como um teórico sobre o amor, mesmo que isso seja feito a partir de um olhar sobre as condições da filosofia - já que o valor atribuído por Badiou a Lacan o faz recriar e recompor a verdade sobre o tema. Lacan se lança e relança no diálogo com Platão a partir do Banquete, no que Badiou identifica também o status de um acontecimento, tendo sido Lacan o primeiro a identificar o Dois do amor ${ }^{74}$ - o que atualizou o valor de verdade deste procedimento genérico, anteriormente corrompido pela eleição do um da metafísica platônica da tradição do pensamento ocidental ${ }^{75}$.

O acontecimento no amor, em Lacan ${ }^{76}$, nomeia-se rencontre (encontro), quando o ser do amor aparece e se instaura nas relações. O mesmo rencontre que Lacan identifica no exaiphnés (de repente) socrático do Banquete de Platão ${ }^{77}$ (na construção de uma potencialização do indivíduo através de uma reorganização e reatualização do vir-a-ser do sujeito) aparece no encontro amoroso de Badiou quando o indecifrável da diferença do amor se sobrepõe à noção de identidade.

\footnotetext{
${ }^{72}$ Cf. BADIOU, Manifest for Philosophy, p. 81, 1999

${ }^{73}$ Cf. BADIOU, Manifest for Philosophy, p. 82, 1999

74 Mesmo que o um do amor, segundo Lacan, sempre subsista, esta imagem de valor unitário e universal paira como uma sombra sobre o dois e suas compossibilidades como a disjunção e o nãorelacional das posições sexuadas (Badiou vê o dois como um excesso em relação ao um, um produto a partir do encontro-acontecimento e da posterior fidelidade a uma verdade).

${ }^{75} \mathrm{Cf}$. BADIOU, Manifest for Philosophy, p. 83

${ }^{76}$ Cf. BADIOU, Conditions, p. 285, 1992

${ }^{77}$ Cf. PLATÃO, O Banquete, 210-e, p.171, 2010
} 
Para Badiou, no seu efeito genérico, o acontecimento refere-se ao não-serenquanto-ser da situação, à quebra de sua ontologia e do mesmo de sua repetição, dando conta dos efeitos do múltiplo de uma situação quando suspenso pela ação de seu inominável, indecifrável e incognoscível de seu situacional pela abertura a uma nova diferença e atualização de seu sítio e estória na história.

Um acontecimento é ligado à noção de indecidível ${ }^{78}$, já que nada nele o justifica como verdadeiro ou falso, válido ou inválido. Badiou clama a necessidade do jogo, apostar que um fato seja a quebra à regra, ao axioma da verdade. Nas palavras de Badiou: "Faça tudo o que você puder para perseverar naquilo que excede a tua noção de perseverança ${ }^{79}$. Persevere na interrupção. Amarre no seu ser aquilo que te amarrou e te quebrou" 80 .

$\mathrm{Na}$ análise de Peter Dews sobre a questão, a quebra seria este salto à consciência subjetiva proporcionada pelo evento, identificada com algo maior e além da sua condição animal ${ }^{81}$. Será por esta emancipação que o homem se elevará da categoria de animal à espécie humana, na busca daquilo que o constitua e o defina como um ser que possa se perseverar, a bem dizer, numa verdade, num institucional possível do homem na busca de práticas reais, de uma outra militância que não a do mesmo. Dews vê isso também como um problema, já que existe nesta militância grãos de excesso, de fanatismo - mesmo que o objetivo final de Badiou seja sempre uma afinação à noção de Bem universal.

Será a partir destas considerações sobre o acontecimento que teremos o aparecimento do sujeito, o responsável por assumir o risco e decisão de nomeá-lo como indecidivel e indicernível - que mesmo sem poder mesurá-lo ou demostrá-lo na sua concretude de verdade, assume o risco de lhe ser fiel, antecipando-lhe sua condição genérica.

\footnotetext{
${ }^{78}$ Cf. BADIOU, palestra Verité et sujet, disponível em http://www.scielo.br/scielo.php, feita pelo autor em 27 de agosto de 1993 no IEA e traduzida por Jean Briant em 21.08.1994

${ }^{79}$ Cf. BADIOU, Ethics: an essay on the understanding for evil, p.48-9, 2001, perseverança, em questão, refere-se à noção de pertencimento a um múltiplo (aux situations multiples), seja ela qual for.

${ }^{80}$ Cf. BADIOU, Ethics: an essay on the understanding for evil, p.47, 2001

${ }^{81}$ Cf. DEWS, Think again - Alain Badiou and future of philosophy, p. 117, 2004
} 
O sujeito é o responsável pela transposição da verdade ao verídico, trazendo para a coletividade a tradução do evento em conhecimento.

\section{Sujeito e Verdade}

"Tout sujet est une exception forcée, qui vient en second lieu...,82

A noção de sujeito só pode ser pensada em Badiou a partir das transformações de um acontecimento, de uma mudança radical dada em determinada temporalidade dos fatos. Existem, assim, na análise de Ed Pluth, dois momentos específicos neste processo: o primeiro se refere aos efeitos do acontecimento, a subjetivação (subjectivation), quando forças e motivações outras irrompem na ordem, numa proliferação de caos e conflito; quando o todo do real se reajusta aos novos elementos configurados pelo evento. Há para o autor, aí, não uma paralisia, mas um desenrolar infinito de cadeias, num eco conceitual do ocorrido. Num segundo momento deste processo, há a continuação desta multiplicação celular do acontecimento no interior de sua geografia, o processo-subjetivo (subject-process) ${ }^{83}$. Sem esta afiliação interna, o acontecimento seria uma mera balbúrdia destrutiva, estilhaços de momentos sem inserção na construção de diferença no real. O processo-subjetivo seria o elo, o atador de nós desta cadeia de atos, pensamentos e imagens que se descortinam no pósacontecimento. Há que se pensar ainda este momento também num lampejo de negatividade, de destruição e negação, mesmo que seguido por um período de reconstrução e reassentamento de verdade.

Tal análise de Pluth refere-se em especial à obra de Badiou Théorie du sujet, quando o autor pensa o sujeito a partir de suas reflexões sobre o maoísmo e as revoluções. Será a partir de seu texto Can politics be thought ? $^{84}$ que a questão

\footnotetext{
${ }^{82}$ Cf. BADIOU, Théorie du sujet, p.102, 1982, tradução: Todo sujeito é uma exceção forçada, que chega em segundo lugar.

${ }^{83}$ Cf. PLUTH, Badiou, p. 23-4, 2010

${ }^{84}$ PLUTH:1, apud, BADIOU, p.23, 2010
} 
permeará outros processuais de verdade, indo além do escopo sócio-político de origem. Pensarmos, por exemplo, a questão do amor remete-nos à imagem do casal, o ser-sujeito por excelência do desenlace amoroso.

Mas o que seria, nas palavras do autor, o sujeito de uma verdade pósacontecimento?

No seu texto Verdade e sujeito ${ }^{85}$, escrito a partir de uma palestra proferida em 27 de agosto de 1993 no IEA, Badiou reinscreve o sujeito além das categorias da tradição do pensamento ocidental, distante da coisa pensante (res cogitans) de Descartes, longe de ser uma fonte de sentido e conhecimento, centro irradiador e subjetivo da verdade do mundo - é a partir de verdades que sujeitos são pensados, identificados. O sujeito em Badiou também não é res extensa, segundo Bruno Besana: não é algo dado, um datum, algo que exista independentemente do material da situação. Para Besana, sujeito é processo e operação, embutidos no possível da existência de um ser humano. É também um resultado, a partir de determinadas situações $^{86}$.

Besana identifica mesmo assim um lado materialista na concepção de sujeito de Badiou, de fundo marxista (o sujeito da verdade é sempre finito, singular e múltiplo), que através de uma mediação lacaniana (o sujeito é o resultado de uma combinação específica de elementos, agregados pelo acontecimento, que se desdobram no simbólico, no imaginário do real e nas propagações e deslocamentos de sua perseverança e resistência ao mesmo do mundo) afirma que o sujeito é o resultado material de um estado de situações e contingências ${ }^{87}$. Ambas as influências, para Besana, se concretizam no excesso no ser do sujeito do acontecimento da verdade, responsável pelo deslocamento e transversalidades do seu genérico.

Há um duplo reflexo nesta condição de uma nova subjetividade que se afirma pelo derramar do acontecimento em uma verdade, que é infinita, e pelo consumar-se

\footnotetext{
${ }^{85}$ Cf. BADIOU, Verdade e sujeito, escrito a partir de palestra proferida em 27.08.1993, com tradução de Jean Briant, http://www.scielo.br/scielo.php?script $=$ sci_arttext\&pid=S0103-40141994000200011

${ }^{86}$ Cf. BESANA, Alain Badiou - key concepts, p.38-9, 2010

${ }^{87}$ CF. BESANA, Alain Badiou - key concepts, p. 39, 2010
} 
na verdade como sujeito, que é local e finito. Daí se concluir que um sujeito não é comensurável a uma verdade, por ser infinita, e ele, o sujeito, finito.

A noção de sujeito tem de ser pensada como pertencimento: é-se sujeito de uma verdade específica - o que nos remete imediatamente a outros conceitos como fidelidade e duração.

Há ainda no sujeito o inominável, a partir daquilo que se subtrai ao nome próprio de um sujeito:

(...) tão singular, na sua singularidade, que é o único a não ter nome próprio. O inominável é esse ponto em que a situação é pensada em seu ser mais íntimo: na presença pura, que saber algum pode circunscrever. O inominável é algo como o real indizível de tudo aquilo que uma verdade permite dizer. ${ }^{88}$

O nome próprio deste sujeito é o que nele há de inumano, vazio, $a$-subjetivo. Ele se realiza como genérico no seu ser múltiplo, na sua apresentação multiplamente informada, não-pontual, transversal e aleatória de sua estrutura. Mas todo sujeito, nos procedimentos genéricos, é qualificado como tal desde que, no amor, haja amor, na arte, arte, na ciência, ciência etc. Há nestes sujeitos também o indiscernível: por estar no interno da situação, seu acesso ao ser da verdade lhe é negado, mesmo sendo ele o responsável pelo sustento de sua estrutura no estatuto local do acontecimento.

Um sujeito não é, por outro lado, coextensivo a uma verdade, já que ela o ultrapassa no seu estado aporético e global. Segundo Badiou, "um sujeito é, assim, pela graça dos nomes, ao mesmo tempo o real do procedimento (o investigando das investigações) e a hipótese daquilo que seu inacabável resultado produziria de novidade na apresentação" 89 . Como exemplo, o autor cita o cristianismo, que ultrapassa os seus sujeitos mais ilustres como São Paulo, Santo Agostinho e São Tomás de Aquino.

\footnotetext{
${ }^{88}$ Cf. BADIOU, Verdade e sujeito, escrito a partir de palestra proferida em 27.08.1993, com tradução de Jean Briant, http://www.scielo.br/scielo.php?script=sci_arttext\&pid=S0103-40141994000200011

${ }^{89}$ Cf. BADIOU, Alain, $O$ ser e o evento, p. 313,1996
} 
Tanto quanto as verdades, o sujeito é raro, dependente de primeira hora do oxigênio existencial de um procedimento genérico. O sujeito é um referimento temporal e local da verdade, que se inscreve na ordem nova do universal do real. Assim esclarece Badiou:

Para que se inicie o processo de uma verdade, é preciso que algo aconteça. Pois, o que existe, a situação do saber tal como está, dá-nos apenas a repetição. Para que uma verdade afirme sua novidade, tem de haver um suplemento, o qual está entregue ao acaso. Ele é imprevisível, incalculável. Situa-se para além daquilo que existe, chamo-o evento. ${ }^{90}$

O sujeito é o responsável pela fixação do acontecimento, aquele que assume o risco no estado de sua ausência semântica, no vazio do significado de seu ser. Há um risco e jogar de dados na eclosão da mudança, cabendo ao sujeito a aposta, o pagar pra ver, iniciando o processo de verificação da verdade e o exame situacional das consequências do axioma que elege e concretiza a diferença em questão. A dificuldade deste trajeto refere-se à falta de referencial, de regras e dogmas que possam apoiar e estruturar aquilo que nasce desestruturado e desregrado. Estamos falando do indiscernível, do aquoso da situação, o des-centro das práticas da experiência, o que abre novas divisões normativas, revertendo a ordem dos termos previamente aceitos. Citando Badiou:

Trata-se, evidentemente, de uma escolha confrontada com dois termos indiscerníveis. Dois termos são indiscerníveis se nenhum efeito de linguagem permite distingui-los; mas, se nenhuma fórmula de linguagem discerne dois termos da situação, está assegurado que a escolha de fazer com que a verificação passe antes por um que por outro não tem apoio algum na objetividade da diferença. ${ }^{91}$

Besana conclui afirmando que o sujeito encontra-se em um ponto suspenso entre um acontecimento e uma verdade universal; ponto este que trata da verificação

\footnotetext{
${ }^{90}$ Idem

${ }^{91}$ Cf. BADIOU, Verdade e sujeito, escrito a partir de palestra proferida em 27.08.1993, com tradução de Jean Briant, http://www.scielo.br/scielo.php?script=sci_arttext\&pid=S0103-40141994000200011
} 
do vazio da verdade e da afirmação retrospectiva, feita verídica, pelo desenrolar dos seus efeitos ${ }^{92}$.

A partir da análise destes elementos axiomáticos da filosofia de Badiou (ontologia, acontecimento, verdade e sujeito), há que se passar agora ao tema central desta dissertação: a reinvenção do Dois do amor.

${ }^{92}$ Cf. BESANA, Alain Badiou - key concepts, p.42, 2010 


\section{Capítulo II: O Amor}

\section{A reinvenção do Dois do amor}

O amor para Badiou é o conhecimento do outro como diferença, como este realmente se apresenta a partir de si próprio. $\mathrm{O}$ amor é um procedimento de verdade único e insubstituível, já que ao nos relacionarmos com a diferença como diferença mesma - a partir de sua condição e identificação - nos fazemos assim inteligíveis um para o outro - e para nós mesmos - no exercício do amor. O amor é construção de um mundo a partir desta condição disjuntiva entre o um e o outro. O mundo do Dois. A pertinência experimental do amor é a sua capacidade de inferência criativa no mundo visto pelo Dois. Uma disciplina. Uma constituição não de um com o outro, mas a partir da figura do Dois de se habitar e povoar um espaço mútuo, eleito e edificado pelas diferenças que se refletem, se relacionam e se compõem disjuntamente.

Há na contingência do encontro particular amoroso um caráter absolutamente inusitado, que beira a suspensão contingencial da vida, como uma insurgência a favor do tempo individual e subjetivo na sua passagem para uma noção de eternidade. Inscrever este amor, microscópico e atômico na sua duração, na sua possível significação universal, é provar que o eterno possa existir no mesmo tempo que a vida, inscrevendo esta verdade subjetiva no procedimento genérico. Vivemos e amamos de acordo com esta ideia de transcendência universal, levados pela ideia de amor pelo próprio amor, inserindo a possível descontinuidade do novo no contínuo do tempo. Se há um critério possível para separarmos o novo do contínuo, a verdade da opinião no amor, "é que ele pode nos conduzir em instâncias de uma experiência fundamental do que é, a fundo, a diferença, na ideia de que se possa experimentar o mundo a partir do ponto de vista da diferença" $"$.

\footnotetext{
${ }^{93}$ Cf. BADIOU, L'éloge de l'amour, p.23, 2009
} 
Não há objetividade no amor, já que, se assim o tratássemos, estaríamos na soma de dois indivíduos, de metades que se fundem e confundem. A soma de um mais um confunde, inunda. Um transbordamento que não vai além da negociação de duas individualidades. O movimento do amor é ligado e condicionado ao outro, mesmo que o movimento do amor aconteça sobre si mesmo, que o seu paradigma, roteiro e deslocamento, lhe advenha do Dois do amor. Há imobilidade neste mover-se para Badiou: o ser do amor se diz numa única situação ontológica, livre de dualidade, nenhum lugar que não o único onde se está - um só universo ${ }^{94}$.

Há que se erigir um terreno e abertura ao imprevisível, a um lugar incomum sem critérios e padrões preestabelecidos, a um acontecimento (évenement) que abre as portas a um saber que é negação dos saberes sabidos e institucionais. Só pode haver no amor conexões possíveis à imanência plural da palavra verdade. $\mathrm{O}$ amor é o que faz do pensamento uma potência ${ }^{95}$, uma força que se expande pela fidelidade ao acontecimento primeiro de erro, que eleva o sujeito ao transcendental do outro, irremediavelmente.

Tratamos de uma potência motora nas ações sobre o próprio devir, arbitrando temporalmente sobre a infinitude e a eternidade. Mas o amor não é uma relação: sua verdade e sua totalidade lhe são também incompatíveis, pois dão-se no vazio do enigma das posições um e dois, homem e mulher, $\operatorname{amado(a)}$ e $\operatorname{amada}(o)$, calcando-se na incompletude do indeterminado ontológico que está no ser do amor e no imperativo de sua fidelidade ao seu acontecimento. O que é libertador.

O real do sexo aprisiona, ilude, nos faz criar a ilusão do um universal. A mediação corporal e o gozo estão sempre na construção de um discurso monográfico, imerso na fictícia aventura de um estado fusional que nunca acontece: "O sexual não une, separa. Que você esteja nu(a), colado(a) ao outro, é uma imagem, uma representação imaginária. O real, é que o orgasmo te leva pra longe, muito longe do outro. O real é narcísico, o elo, imaginário." ${ }^{96} \mathrm{O}$ sexo é o túmulo espelhado de si

\footnotetext{
${ }^{94}$ Cf. BADIOU, Pequeno Manual de Inestética, p. 149, 2002

${ }^{95}$ CF. BADIOU, São Paulo, p. 105, 2009

${ }^{96}$ Cf. BADIOU, Éloge de l'amour, p. 23, 2009
} 
próprio, conduzindo o corpo na busca de sua satisfação narcísica. $\mathrm{O}$ amor nos conduz ao ser do outro: o sexo, a nós mesmos, irremediavelmente.

O amor é o que há de mais próximo ao aleatório do acontecimento, já que desprovido de critério; subverte normas e predicados anteriores: o amor é, acontece, aparece - mas está na lógica do improvável, do impossível, do incoerente. Alain Badiou corajosamente retoma $\mathrm{o}$ debate sobre $\mathrm{o}$ tema verdade $\mathrm{x}$ amor; $\mathrm{e}$ confraternizando-se com Platão, declara categoricamente que o amor é uma operação constitutiva de verdade. Seu pensamento sobre a questão implica criarmos uma ruptura no contínuo da opinião no presente através do encontro de diferenças, resgatando no amor aquilo que ele, o amor, ainda não é - quando no frescor de sua emergência, fora das categorias possíveis do amor. Este acontecimento permanece uma alteridade perante si mesmo, como uma verdade nua e alada, pairando entre o voo e o retorno ao solo - calada na sabedoria de sua indeterminação. Disso depende a verdade: ser formulada como reinvenção - e reinventando as palavras de Rimbaud, acrescenta Badiou: “(...) reinventar o amor é reinventar a reinvenção" 97.

O amor em Badiou é uma verdade como operação, o trabalho de um sujeito que, fiel à irrupção de uma ideia no mundo, extrai suas consequências e assim transforma o seu próprio mundo. E a lei do mundo, no seu pensamento, é a permanente transformação daquilo que é único e de real valor: uma diferença que se propaga além do espelho relacional dos protótipos e papéis sociais.

Se o ideal de uma verdade é baseado num futuro que nunca chega, a verdade mesma está sempre um passo atrás de nós. Seu determinante não é a imaginação, mas a atualidade de seu pensamento, pois quando o amor se torna pensável, isso quer dizer que algo dele já adentrou no mundo da verdade. $\mathrm{O}$ amor se torna amor quando amantes se declaram, no enunciado de discursos de afeto e promessas. Pergunta-se Badiou sobre o tema: "O que é o mundo quando experimentado a partir do Dois, e

${ }^{97}$ Cf. BADIOU, Éloge de l'amour, p.36, 2009 
não do um? O que é o mundo quando examinado, praticado e vivido a partir da diferença, e não a partir da identidade?"98

O amor incorpora sujeitos na verdade, na vivência de uma verdade que tem por medida ela mesma. Os problemas do amor começam quando incorporam-se medidas a partir de si mesmo, quando o homem-medida vira o princípio e fim de todas as coisas, ou quando olhamos o homem de maneira cética, não estando à altura de se incorporar numa verdade 99 . A norma para o sucesso amoroso consiste numa indiscernibilidade entre o critério da vida e o critério de verdade, quando a verdadeira vida e a vida da verdade se confundem e se incorporam com o sentido mesmo da consistência subjetiva do amor.

Há um critério de excepcionalidade no amor dentro de seu acontecimento, que o define ontologicamente como uma multiplicidade genérica, de seu aparecer como um corpo. Tal critério deve também ressoar no seu aparecer individual externo com traços de individualidade e exceção, quebrando a legalidade monótona e repetitiva do mundo. O sujeito do amor, ao quebrar esses códigos, se outorga o status de valor simbólico ${ }^{100}$, pois se encontra fora da redução imediata de sua mera corporalidade: ele é diferença instaurada em si mesmo, dilatação de sua finitude, incorporada ao código canônico de uma verdade. O indivíduo se transborda, se identifica com tudo aquilo que o excede na infinitude da verdade do amor e de seu imaginário prévio ${ }^{101}$.

Esta criação de uma verdade a partir do Dois do amor é uma proposição existencial, uma nova circunscrição que retiraria o indivíduo de sua individualidade para a sua diferença. A noção de identidade nos remete ao imemorial da essência, aos códigos sociais de conduta, enclausurados nas instituições como família e sociedade. Recompor livremente as formas historicamente inscritas da sociedade em novos modelos de afeto e relação parece ser o objetivo de Badiou com sua ideia do Dois do

\footnotetext{
${ }_{98}^{98}$ Cf. BADIOU, Éloge de l'amour, p.26, 2009

99 Cf. BADIOU, Pour aujourd'hui: Platon!(3) - Seminaire Alain Badiou, 2009-2010, em http://www.entretemps.asso.fr/Badiou/seminaire.htm

100 Cf. BADIOU, Pour aujourd'hui: Platon!(3) - Seminaire Alain Badiou, 2009-2010, em http://www.entretemps.asso.fr/Badiou/seminaire.htm

${ }^{101}$ Idem ${ }^{99}$, o imaginário aqui em questão trata da dilatação e incorporação do sujeito na verdade do amor, no real local de seu acontecimento, diferente da ilusão ou do irreal dos fatos sobre pretensos objetos relacionados ao amor.
} 
amor. Uma abertura à experimentação, na busca de novos continentes possíveis sem as tipologias prévias engessadas pela história, leis e parâmetros conjugais da heteronormatividade ocidental. "A vida verdadeira é a vida que aceita sua incorporação no devir de uma verdade" ${ }^{\text {102 }}$ : é pensar a vida como potência de uma orientação maior que a vida mesmo, além da existência cotidiana de um indivíduo qualquer.

Pluth $^{103}$ identifica um contraponto entre o amor e a política em Badiou: o amor possui elementos fraternizantes, funcionando como um adjunto humanitário ao status quo da política, levando as respectivas diferenças dos amantes a criarem vínculos que corroboram aqueles já existentes na sociedade. Pluth parece deslumbrar aqui um efeito cascata do amor sobre o todo do tecido social, criando uma utopia dos afetos sobre as relações institucionais da cidade, estado, país.

O que orienta Badiou neste pensamento é o mesmo que orientou Platão sobre a ideia do amor, só que na construção de algo além do conhecimento ou do saber: no aparecimento de uma verdade no mundo. $\mathrm{O}$ amor é o farol e guia para o indivíduo na sua descoberta e aceitação da diferença refletida nos olhos do(a) amante: aquela opaca, que aparece, que nada reflete e que não é imagem de verdade nenhuma.

Badiou busca na subjetividade amorosa a fórmula que desconstrua toda noção de fórmula e de sujeito. Mas onde estão os novos atores sociais a escrever as novas linhas para este teatro de dois personagens? "O amor deve ser reinventado, mas também e simplesmente defendido, pois está ameaçado de todas as partes" ${ }^{\text {"104 }}$ - não há amor sem risco, não há precipício que não estruture e condicione uma viagem amorosa. Se o amor tornou-se uma variante de um hedonismo corporal ilusório e intenso, é porque perdemos a coragem de nos lançarmos na mais incerta e profunda experiência de alteridade da condição humana.

102 Cf. BADIOU, Pour aujourd'hui: Platon!(3) - Seminaire Alain Badiou, 2009-2010, em http://www.entretemps.asso.fr/Badiou/seminaire.htm

${ }^{103}$ Cf. PLUTH, Alain Badiou a critical introduction, p. 147, 2002

${ }^{104}$ Cf. BADIOU, Éloge de l'amour, p. 13, 2009 
O amor é uma disciplina, cujo trabalho requer visibilidade, dedicação, construção: os corpos dos amantes devem projetar esta condição de fidelidade aos procedimentos do amor. O jogo do desejo e do êxtase fazem parte desta prova, na incorporação da prova de amor ${ }^{105}$.

Sábio, artista, militante e amante são os papéis exigidos pela filosofia do sujeito contemporâneo: reinventar o risco e a aventura, defendendo a participação do amor neste momento tão intenso de reinvenção e inovação do homem, é tarefa da filosofia para este pensador. É o que analisaremos a seguir.

\section{O amor na obra de Badiou}

O amor é a consciência da inserção de duas vidas na verdade de uma ideia: sua vida é a medida e fim desta ideia excepcional e infinita, a se destacar no banal repetitivo do tempo. Hallward ${ }^{106}$ destaca a necessidade do real da experiência no real do amor: há que se percorrer os caminhos, trilhar o não-trilhado, cair e levantar, sofrer e fazer sofrer no aprendizado da pedagogia do outro. É a concretização da verdade privada e intransferível por excelência, e talvez por isso mesmo, a mais ausente na produção de pensamento de Badiou, ele conclui. O tema encontra-se disperso em sua produção literária, mesmo que em seu trabalho inaugural sobre ontologia e acontecimento, $O$ ser e o evento (1988), ele chegue a duvidar de sua existência:

De fato, considero que, na esfera situacional do indivíduo tal como a apresenta e pensa, por exemplo, a psicanálise - o amor (se é que ele existe, mas diversos indícios empíricos atestam que sim) é um procedimento fiel genérico, cujo evento é um encontro, cujo operador é variável, cuja produção é infinita e indiscernível, e cujas

\footnotetext{
105 Cf. BADIOU, Pour aujourd'hui: Platon!(3) - Seminaire Alain Badiou, 2009-2010, em http://www.entretemps.asso.fr/Badiou/seminaire.htm

${ }^{106}$ Cf. HALLWARD, Badiou a subject to truth, p.185, 2003
} 
investigações são os episódios existenciais que o par amoroso vincula expressamente ao amor. O amor, portanto, é uma verdade dessa situação. Chamo-a de individual porque ela não interessa a ninguém, salvo os indivíduos concernidos. ${ }^{107}$

Ao longo de suas palestras, seminários, entrevistas e aulas, o tema aparece não sem revisões e contradições, com uma certa volatilidade em alguns conceitos (ciúme, família, o ultra-um do amor...), mesmo que sua afiliação a Lacan permaneça o seu eixo teórico sobre a questão. A questão do sexo, por exemplo, oscila entre o ilusório e o simbólico do amor, como visto em seus seminários e aulas dadas entre 1996 e 1998. Já no seu texto de 2009, A cena do dois, Badiou parece seguir Lacan ao afirmar que o amor aparece como um suplemento à falácia fusional do sexo. Ambos os momentos concordam que se trata de uma prática sempre centrada no prazer pessoal, distante da verdade do Dois.

Será com a publicação de Conditions (1992) que o amor será analisado na sua compossibilidade com a verdade, respaldado pela sua afiliação às análises de Lacan sobre o desejo e a transferência. Após uma hibernação de quatorze anos, segue-se Éloge de l'amour, quando o tema é discutido em entrevista feita por Nicolas Truong para a série Théâtre des Idées do Festival de Avignon, tornando-se um best seller na produção de Badiou - o que mostra o grande interesse público pelo tema. Talvez devido à idade, esta longa entrevista finalmente descortina sua militância eróticosubjetiva, isto é, quando o vemos a serviço da verdade no amor, tratando o tema como a mais intensa experiência que um ser humano possa construir na sua subjetividade.

Nessa recuperação filosófica do amor, assim analisa Vladimir Safatle este livro:

Ele retoma como modelo de uma vivência da diferença capaz de construir mundos a partir de pontos de vista descentrados, com sujeitos que não procuram apenas a conformação do outro a um conjunto de expectativas e imagens fantasmáticas prévias,

${ }^{107}$ Cf. BADIOU, O ser e o Evento, p.268, 1988 
instaurando no amor a capacidade de nos levar a uma região rara onde encontramos coisas desprovidas de gramática, onde precisamos

apreender a amar coisas desprovidas de gramática. ${ }^{108}$

\section{Amor e diferença}

Há algo que toca em particular a condição humana ao lidar com o outro que não sou eu mesmo. Ao ser tratado por aquele outro no espontâneo de sua condição que tanto faz revelar, consequentemente, também a minha condição de outro, evidenciam-se as diferenças entre as partes como a nossa incompatibilidade e disjunção. Existem territórios traçados a partir desta possibilidade cartográfica na vida de um indivíduo que risca fronteiras, relevos e estados processuais que demarcam o outro no confronto diário das atitudes afetivas. $\mathrm{O}$ "porque era ele, porque era eu"109, de Michel de Montaigne, hoje, pelo olhar badiouniano, deve ser analisado no confronto das diferenças, do irremediável instaurado pelo condicional do outro como alguém que não eu mesmo e que se condiciona, paralela e igualmente, no espelho desta condição. Talvez a máxima deva ser reescrita seguindo os propósitos da diferença mesmo, em contraponto às questões de identidade: porque era ele, e não eu, e porque era eu, e não ele!

Há um reflexo destas duas imagens distintas que se espelham no impossível de um foco comum: um olhar sempre estrábico e desviante, já que não há física possível no um do olhar, no um do pensar, no um do amar. A finitude de ambos é uma das poucas certezas, e a existência de fronteiras e barreiras duramente erguidas, fantasmas criados pela aurora dos tempos e abortados na primeira hora no ideário do um do amor, devem ser repensadas na construção da eminência do Dois - não como empecilhos, mas como condicionantes para o horizonte de verdade que pode se abrir pelo acontecimento amoroso.

${ }^{108}$ Cf. SAFATLE, em http://www1.folha.uol.com.br/fsp/ilustrad/fq0603201012.htm, em resenha sobre o livro Elogio ao amor, de Alain Badiou

${ }^{109}$ Cf. DE MONTAIGNE, em http://www.gutenberg.org/files/3600/3600-h/3600-h.htm\#link2HCH0027 
Há que se confiar no acaso, com um voto de coragem e loucura para ingressar na diferença do outro, podendo-se assim erigir as bases para que se experimente o mundo a partir da ótica da diferença mesma ${ }^{110}$, o que é totalmente distinto de vivenciar a diferença como propõe a ética de Levinas ${ }^{111}$, ou o grande-outro que é Deus - ou ainda preceitos éticos a partir da alteridade (mesmo que o amor retenha aspectos tocantes à ética).

A diferença em questão dá-se no encontro pelo acontecimento do outro, não no seu aspecto relacional, mas sim no que se refere a uma arquitetura possível de um novo mundo descentralizado, alheio ao esquecimento oblativo do amor romântico (o que implicaria uma máxima: eu não me esqueço nem me anulo por amar o outro).

As diferenças arquitetam o paradoxo de uma identidade de visão de mundo comum, de uma promessa de construção ainda amanhã e depois, incorporando nesta subjetividade amorosa um desenvolvimento que me transborde além de minha individualidade para o ideário do amor. Este paradoxo refere-se também à experiência identitária da diferença mesma, como diferença. Seria esta a comunicação mais completa no âmbito da verdade amorosa: a vivência do ser do outro como outro ser. Nas palavras de Badiou: “(...) devemos mostrar que, na realidade, existe uma potência universal do amor, e que ela é simplesmente o que nos possibilita de fazermos uma experiência positiva, afirmativa e criadora da diferença" ${ }^{\text {"112 }}$.

Existem para o autor sistemas políticos, científicos, artísticos e amorosos. No amor, isso se dá por um processo particular entre indivíduos, sob o signo universal da Ideia, mesmo que esta universalização da ideia seja um processo, uma ideação ${ }^{113}$. Viver segundo a ideia, é viver no procedimento de verdade, numa comunicação plena no potencial econômico que toda verdade pode construir globalmente.

A tradição nos fez crer que a ideia (eidos) seria o freio da comunicação e troca, bem como do progresso e do devir. Mas sem esta possibilidade comunicativa,

\footnotetext{
${ }^{110}$ Cf. BADIOU, Éloge de l'amour, p. 23, 2009

${ }^{111}$ Idem, p. 27

${ }^{112}$ Idem, p. 58

113 Cf. BADIOU, Pour aujourd'hui: Platon!(3) (Seminaire Alain Badiou), 2009-2010, em http://www.entretemps.asso.fr/Badiou/seminaire.htm
} 
estaríamos apenas no sistema circulatório de impressões, na corrente de uma coletividade sem marca e registro. O risco seria de identificarmos nesta arquitetura uma função de modelo, de verdade da verdade, já que este construto segue normas próprias, intransferíveis - um sítio que se abre no mundo.

O estado de sítio do amor ${ }^{114}$ acontece pelo encontro da incompatibilidade mesma, um trabalho da diferença radical da disjunção. É a potência de $x$ em confronto e encontro com a potência de $y$. Isso não quer dizer que a incompatibilidade imediata dos dois termos cesse ao se dar o face-a-face ou mesmo que uma relação se estabeleça; mas sim que a existência de um termo em comum, que se relacione tanto com $x$ como com $y$ começa a acontecer, sem que nada aconteça em detrimento à diferença e incompatibilidade iniciais de $x$ e $y$. Cria-se assim o procedimento genérico do amor, o que podemos também chamar de mundo do amor. Hallward vê o amor em Badiou como o único processo em que a diferença dos sexos não é somente sofrida, articulada, experimentada, mas também pensada: é no amor onde o pensamento se livra das amarras do um, no exercício da economia das leis do mundo do Dois ${ }^{115}$.

\section{Amor e o Dois}

L'amour n'est pas à proprement parler une possibilité, mais plutôt le franchissement de quelque chose qui pouvait apparaître comme impossible. ${ }^{116}$

Badiou analisa o amor no Pequeno Manual de Inestética ${ }^{117}$ como um movimento que deva ser feito não de um lugar para um outro, mas, a priori, para si mesmo, sem nenhum percurso geográfico. É uma ida em direto incesto com a volta,

114 Cf. BADIOU, Théorie axiomatique du sujet (Seminaire Alain Badiou), 1996-1998, em http://www.entretemps.asso.fr/Badiou/seminaire.htm

${ }^{115}$ Cf. HALLWARD, Badiou a subject to truth, p.186, 2003

${ }^{116}$ Cf. BADIOU, Éloge de l'amour, p.60, 2009, trad.: O amor não está necessariamente a falar sobre uma possibilidade, mas antes de tudo, um cruzamento de alguma coisa que parecia antes impossível.

${ }^{117}$ Cf. BADIOU, Pequeno manual de inestética, p.149, 2002 
quando se deslumbra de outra perspectiva o Dois, quando a diferença que se dá no interno das relações se faz clara na constatação real de que existem dois, não um, naquilo que no dois há de irremediável: ele não é dois, ele é um e outro um, juntos, no exercício do Dois.

Analisando a obra de Beckett, escreve o autor:

Quando Beckett conta o par, indica claramente que recai sobre o dois, mas que não é dois, é o dois. O par é o dois, mas acrescido ao um, não perfaz três. Acrescentando o par ao um, você sempre tem dois, o dois do outro após o um. Só a cabeça perfaz três. O três é o pensamento. ${ }^{118}$

O que fica nítido nesta estruturação numérica é a constatação de que são dois polos de experiências distintas, duas posições que se olham e vislumbram pelo olhar que só sabe ser olhar a partir de si mesmo, na finitude daquilo que sempre será um, pelo um e para o um. A experiência é tomada na apresentação irrefutável da coisa do dois, no contar-por-um que é o outro quando pelo olhar do outro outro. Se existem duas posições, aqui, elas são disjuntas, sem zonas de coincidência ou interseções ${ }^{119}$. O todo do amor atesta isso: que uma posição não é a outra, que não há aspecto relacional algum que possa interligar o real da experiência entre os amantes. Se há uma experiência total da coisa, especialmente no três do pensamento, será no disjunto das posições que se dará o estado da coisa como apresentada, a olhos vistos.

A tradição da metafísica nos deu o um; a da dialética, o dois. Pela segunda inferimos o um como parte movente, vivo; diferença que afirma a sua condição de não-um, num outro lugar e espaço (na alteridade, no deslocamento do pensamento e no pensamento do outro sobre nós a nos in-definir). Pela ótica do um absoluto, só conseguimos imperfeições e imagens, ecos mal ouvidos da verdade imemorial, de uma teologia da existência que nada tem a ver com o recomeço real e constante da vida no múltiplo da existência.

\footnotetext{
${ }^{118}$ Cf. BADIOU, Pequeno manual de inestética, p.125, 2002

${ }^{119}$ Cf. BADIOU, Condiciones, p. 245, 2003
} 
Na Teoria do Sujeito, Badiou analisa a substância em Espinosa, que para ele traz o espectro do dois na imanência da substância através das relações entre atributos, extensão e o pensamento, e cita o filósofo (Ética I, escólio da proposição 10): "Um ser absolutamente infinito deve ser necessariamente definido como um ser que é constituído por uma infinidade de atributos" ${ }^{\$ 20}$, para logo em seguida concluir:

Que o homem não aceda ao verdadeiro que pela conexão adequada entre a Ideia e a coisa, ou pela alma e o corpo, e que não possa pensar a Substância que na sua dupla infinidade atributiva como extensão e pensamento, o que atesta exclusivamente o seu limite: este Dois é uma imperfeição de infinitos. O Um pressuposto não tem por efeito senão a multiplicidade integral, infinita dos infinitos. $^{121}$

Não há assim diferença no seu aspecto forte, já que cairíamos de novo no múltiplo a serviço da identidade ou ainda da metafísica - ou na tradição das polaridades criadas pelo mundo judaico-cristão, do velho testamento ao marxismo. Se assim pensássemos, estaríamos construindo um lado sempre em inferioridade ao outro, numa escala hierárquica de forças e formas - o que levaria possivelmente à destruição de um pelo outro. O dois é muito mais forte que a luta manipulativa do um, está além das contradições monocórdias do espectro do mesmo ou da identidade fusional do amor romântico.

O princípio de dissimetria deve servir ao jogo de posições pela sua inversão possível, não pela sua constância presencial ou invariância. Se todo processo do dois envolve contradições, a do Dois do amor está fora do jogo das contradições da história, já que se centra na bipolaridade eventual do encontro de dois indivíduos e o seu destaque do eixo do cotidiano. As partes não se incluem no jogo ou equilíbrio do Dois: estão num estado de anomia, de incerteza de terrenos, na exploração de um horizonte sem margem - mesmo que haja uma margem inicial de partida neste encontro de múltiplos. O múltiplo em questão precisa do real do acontecimento e da verdade para que se constitua na sua identificação à disjunção - e este é o papel do

\footnotetext{
${ }^{120}$ Cf. ESPINOSA, Èthique, apud BADIOU 1982: p.40

${ }^{121}$ Cf. BADIOU, Théorie du sujet, p.40, 1982
} 
amor na questão identitária, elevar os amantes ao cerne deles mesmos, na derrocada do um pelo real do Dois.

Se há um impasse na formalização do real pela diferença, o amor é o retorno sobre o estado inaugural do resultado inicial de um e outro um, o ilimite como retorno a si mesmo, o passe-livre no impasse do real e no contar-por-um estruturado, ou o que desloca a diferença do distinto para o heterogêneo.

Ainda em Théorie du sujet: "Tudo se sustenta a partir do real, mas o nosso real, por sua vez, não se sustenta senão por isso: que existem dois sexos, duas classes. Tratem de se virar com isso, sujeitos de toda experiência!"122 Há um clamor nesta afirmação pelo filósofo, que brada pelo potencial da insurgência do novo, da reinvenção de algo até então engessado pelo um do ideário do mesmo. Se o um condiciona o mesmo à impotência, o Dois é potência para novos alicerces em novos terrenos, na busca de um território virgem e ainda inexplorado.

Peter Hallward vê aí a máxima do pensamento do autor na análise da produção de verdades do homem a partir do irrefutável do real do Dois da experiência: a mais nobre das tarefas é a de se produzir pensamento sobre o Dois, exercícios sobre o dois. Todo o resto, para ele, é um questionamento sucessivo a partir desta questão na obra de Badiou ${ }^{123}$.

Isto é, para o autor, influência direta do pensamento de Mao Tsé-Tung: "Se você possui uma ideia, divida-a em duas." ${ }^{124}$ Será pela ideia do dois que se chegará ao um, à verdade universal; e não ao contrário. O entre relacional das posições, para Hallward, só é percebido pelo terceiro elemento, no externo do sítio da situação. O que o terceiro percebe é a figura do casal, a subjetividade amorosa encarnada.

O que há é a desconexão: o ser de cada um dos amantes é desconectado do ser do outro, já que se assim não o fosse, haveria uma experiência interiorizada de cada um pelo outro - o que seria um processo de osmose com o ser de cada um com o Dois. Num primeiro momento os envolvidos encontram-se num estado de ausência

\footnotetext{
${ }^{122}$ Cf. BADIOU, Théorie du sujet, p. 133, 1982

${ }^{123}$ Cf. HALLWARD, Alain Badiou a subject to truth, p. 46, 2003

${ }^{124}$ Cf. MAO, apud BADIOU: Théorie du sujet, 1982:131
} 
de ser, numa ataraxia pela mudança de ângulo da visão ${ }^{125}$, pois é o Dois que fala, que entorpece e faz o sujeito transbordar pelo excesso de si devido à afirmação de sua diferença.

É a máxima criadora do amor em ação, quando o sujeito está imerso nesta sua condição mesma, em si, quando a ordem simbólica da diferença se impõe ao resto do mundo ao redor.

Badiou critica a via sartreana do amor em Conditions ${ }^{126}$, por se tratar de uma oscilação objetal entre amantes (ao tratar o outro como objeto, desenvolve-se aí o aspecto sádico da relação; ao ser tratado como objeto, o oposto, o lado masoquístico). Em ambos os casos, o dois em questão seria sempre uma maquiagem do um, por se tratar sempre de uma questão identitária, mesmo que em alternância de posições. Seu olhar crítico também paira sobre o amor romântico ${ }^{127}$, que queima e consome os amantes numa existência evidenciada pela intensidade de afetos: é a ilusão do um, a concepção de partes que se perdem em um ato heroico de entrega e perda. Estamos no encômio de Aristófanes ${ }^{128}$ no Banquete de Platão, no mito do andrógino e das metades perdidas que se reencontram pelo amor. A paixão, o encontro e o êxtase são as marcas desta construção que se justifica como uma aventura obstinada, quase épica. Não há construção nem duração nesta proposta, já que sem uma subjetividade pensada e erguida pelo acontecimento do amor não há percurso através do tempo, do mundo ou no ser do indivíduo.

O amor cético também é analisado com ressalvas por Badiou. Por se tratar de uma quimera humana, este amor é considerado como fruto de uma imaginação exacerbada, aplicada sobre a realidade do desejo corporal. O que há é o encontro e a duplicação entre desejos, gestos e práticas sexuais que motivam os envolvidos na constatação da prova material do gozo. Estes querem crer que o amor não seja mais do que uma maquiagem cultural sobre a reprodução biológica e necessária da espécie.

125 Cf. BADIOU, Pour aujourd'hui: Platon!(3) - Seminaire Alain Badiou, 2009-2010, em http://www.entretemps.asso.fr/Badiou/seminaire.htm

${ }^{126}$ Cf. BADIOU, Condiciones, 249, 2003

${ }^{127}$ Cf. BADIOU, Éloge de l'amour, p. 33-35, 2009

${ }^{128}$ Cf. PLATÃO, O Banquete, 189d - 193a, 2011 
Não que esta prova material que é o sexo não tenha valor para Badiou - mas ela não é tudo. Se ela é o que separa o amor da amizade, ela é também uma constatação de entrega, da capacidade de se doar ao outro.

Há uma marcação material do amor que deve ser feita, e essa marca está na sexualidade, no entrelace de corpos, no dispositivo visual do entrelace do desejo que se cristaliza, de maneira não subjetiva, no limiar da verdade e do real do sexo.

\section{Em Éloge de l'amour encontramos:}

A cerimônia de corpos é o penhor material da palavra, é através dela que se passa a ideia de que a promessa de uma reinvenção de vida será mantida, no emergir dos corpos. Mas os amantes sabem, até no mais violento delírio, que o amor está lá, como um anjo guardião dos corpos, ao despertar, pela manhã, quando a paz desce sobre a prova que estes corpos compreenderam a declaração de amor. ${ }^{129}$

Se há uma potência imediata que se constrói pelo sexo, ela está em direta oposição às condições pedidas pela verdade amorosa. Há que se pensar na rotina, na repetição, no cuidado que a palavra deva ter ao se dirigir ao ser do outro. A palavra está ligada diretamente ao corpo, ao orgânico das relações no amor. Pensamento e corpo se expõem, incestuosamente, nas práticas amorosas. É tênue a linha divisória entre "isso é um corpo" ou "isso é uma ideia"130. Há o dois que se recompõe por estas práticas morfo-corporais. O verdadeiro sujeito do amor é criado para o devir do casal, não para satisfações próprias, irremediavelmente individuais, como as do sexo.

Ao interpretar a famosa frase de Lacan sobre a inexistência de relação no ato sexual no seu seminário sobre Platão $(2009-2010)^{131}$, Badiou chama atenção aos alunos sobre o valor de comunicação real existente no amor: só ele é elemento de uma real engenharia humana. A sexualidade é aqui relevada como a grande voz da

\footnotetext{
${ }^{129}$ Cf. BADIOU, Éloge de l'amour, p. 38, 2009

${ }^{130}$ Cf. BADIOU, Éloge de l'amour, p. 73, 2009

131 Cf. BADIOU, Pour aujourd'hui: Platon!(3) - Seminaire Alain Badiou, 2009-2010, em http://www.entretemps.asso.fr/Badiou/seminaire.htm
} 
espécie, mas desprovida de elementos relacionantes com a verdade. Não há comunicação real no ato sexual; tanto para Lacan como para Badiou o que há é a prática e a busca do prazer próprio, já que nem o gozo nem o corpo levam ao cerne do corpo ou gozo do outro.

Há uma energia disjuntiva no inaugural do Dois do amor que busca uma simbologia possível da declaração eu te amo. Há a procura de uma semelhança física a este enunciado que se metaforiza no corporal imanente do sexo. O aparecer e desaparecer do ser do amor está neste ritual que marca a sua condição onipresente, entre o ter lugar e a supressão, entre o reconhecível do sexo e o irreconhecível do amor $^{132}$. Citando Badiou:

O paradoxo deste tipo de amor é sem dúvida o fato que o amor é tanto uma experiência excepcional da infinitude da existência - o que cria a pausa do Um através da energia do acontecimento de um encontro - e o ideal do devir de uma emoção a princípio ordinária, uma amarração desta existência. Quem não experimentou isso no auge do amor, quando se está totalmente reduzido à anônima e pura exposição da vida de uma outra pessoa? O poder do Dois é esculpir numa existência um corpo, uma individualidade banal, diretamente a partir do céu das Ideias. ${ }^{133}$

Junto a isso, Badiou vislumbra também um lugar para o sexo: uma atopia suspensa do resto da revelação amorosa, que se projeta também no infinito do mundo; uma nostalgia do onipresente do prazer dos corpos do amor. Deste lugar nenhum se constrói uma projeção que remete o sujeito do amor ao seu acontecimento original. $\mathrm{O}$ sexo é o intervalo infinitesimal vazio entre o início e o infinito do Dois do amor, que pode funcionar de abrigo e proteção aos perigos externos, aos sítios de exceção que pedem o labor contínuo de seus sujeitos.

\footnotetext{
${ }^{132}$ Cf. BADIOU, Pequeno manual de inestética, p. 89, 2002

${ }^{133}$ Cf. BADUOU, Logic of the Worlds, p. 32, 2009
} 


\section{Amor e as posições homem e mulher}

"O amor é o comunismo mínimo"134 das verdades. A incompatibilidade individual a serviço da ideia do todo do amor, seguindo o sentido original de communis no latim: universalidade. É o que possibilita ao homem lapidar sua própria história e modelo, o que faz com que cada indivíduo tenha a idealização de seu território existencial ao criar suas regras e respirar livre para lidar com o mundo e o todo das vicissitudes da vida. Seu valor transcendental se concretiza na imanência de sua verdade, nos revelando a potência do mundo e de sua completude. Mundo, verdade e humanidade projetam o sujeito do amor para o todo do humano.

A Humanidade (com $\mathrm{H}$ maiúsculo) é o corpo histórico onde acontecem as verdades, o suporte abstrato da progressão de saber, amor, ciência, política e arte. A humanidade só se atesta e se afirma se estas verdades acontecem no campo da sua emancipação (política), do seu conceitual (ciência), das suas criações (arte) ou de seus amores (quando não reduzido a um sentimentalismo ou sexualidade). Será pelo sujeito destas verdades que se comporá a imanência do verídico do homem: o militante (pela política), o sábio (pela ciência), o poeta, pintor, dançarino etc (pela arte) e pelo Dois, amante e amado (pelo amor) ${ }^{135}$.

As verdades desta composição do humano, para Badiou, são supostamente sexuadas. Uma posição homem e uma posição mulher. Há um pensamento para a verdade política masculina e um outro para a feminina. Uma arte feminina e uma outra masculina etc.

O amor é o terreno para se lidar com este paradoxo, no cerne de sua existência. Como pensar uma construção do Dois, pela disjunção, na consumação de diferenças, sem levar em conta a questão identitária se a mesma se sexualiza em duas categorias? Categorias essas carregadas de preceitos e posicionamentos, remetendo a um $U m$ inevitável de suas posições? Segundo Jöttkandt:

\footnotetext{
${ }^{134}$ Cf. BADIOU, Éloge de l'amour, p. 77, 2009

${ }^{135}$ Cf. BADIOU, Conditions, p. 260, 1992
} 
Nada da experiência é o mesmo para as posições homem e mulher. Nada. O que quer dizer: as posições não dividem a experiência, e não há apresentação que afete transversalmente as posições, de tal forma que não existem áreas de coincidência ou interseção. $^{136}$

O amor não revela este paradoxo, mas dele trata: é a arena por excelência da apresentação destas posições intercambiáveis na verdade do Dois.

$\mathrm{Na}$ análise de Sigi Jöttkandt, existe um processo que se descortina a partir do real do acontecimento que origina as posições homem e mulher na teoria do amor de Badiou. Há algo na construção da cena do Dois que cola nos amantes após a constatação da disjunção. Existiria um momento de suspensão quando os amantes se percebem como diferentes, distantes do mundo da fusão e da ilusão do um, quando o aspecto não-relacional do sexo se faz real e existe um excesso e transbordamento que os contagia. É nesse instante que as posições homem e mulher se aderem aos amantes, neste movimento que oscila entre as polaridades da diferença e da identidade, do individual e do universal. Ela diz:

Simplesmente colocada, a nominação do amor, a declaração "Eu te amo", emerge da cena do Dois para abraçar o você do amante individual e o Você do todo da humanidade. Neste respeito, o único amante individual se transforma ao mesmo tempo num sujeito de verdade que se outorga a "função humanidade". ${ }^{137}$

Jöttkandt não identifica na obra do autor como este processo daria crédito ao lado criativo e construtivo do amor. A consciência da disjunção criaria estas posições simbólicas, neste ir e vir da ideia universalista do amor e de sua transversalidade com as outras verdades, quando se erige a figura de um sujeito que é atravessado pela fidelidade ao Dois que o suspende do tempo, inserindo-o na eternidade. Mas não estaria aí o trabalho personalíssimo da subjetividade amorosa? Um horizonte de

\footnotetext{
${ }^{136}$ Cf. JÖTTKANDT, Alain Badiou key concepts, p. 75, 2010

${ }^{137}$ Cf. BADIOU, Pequeno manual de inestética, p. 78, 2002
} 
criação, sem metodologia e regras próprias, extirpando da verdade o peso da verdade da verdade? Ou resgatando o seu vazio, como visto anteriormente?

Assim esclarece Badiou:

Sujeitos do amor. O mundo da verdade amorosa faz aparecer o absoluto do Dois, uma profunda incompatibilidade, uma separação energética. Sua fórmula seria m e f: não há relação entre os sexos. Normalmente os sexos são como duas diferentes espécies (isso a partir da expressão de Lacan). O acontecimento (o encontro amoroso) é o que dá a partida para o aparecimento da cena do Dois, encapsulada na declaração que estas duas espécies possuem algo em comum, um "objeto universal" (u) do qual ambos participam. Poderíamos assim dizer que o enunciado existencial é: existe um u de tal maneira que $\mathrm{m}$ e f nele participam. ${ }^{138}$

O que o $u$ na situação quer dizer, é uma incógnita, já que diz respeito só e somente à contingência particular do encontro em questão, mesmo se este estágio representa um erro inicial do amor. O $u$ é tanto a relação objetal universal do amor quanto o excesso de ser que contagia o outro ser - que dá apoio à verdade do Dois. Ambas devem ser subtraídas do ser do amante ao longo da construção subjetiva. Este primeiro estágio é feito por ambas as posições, que se alternam nestas duas condições de $u$, construindo práticas e questionamentos até se chegar à ontologia do real do Dois: a disjunção.

Se o amor é a mais irracional, violenta e abrupta experiência que um indivíduo possa sentir na vida, cá está a sua passagem para o irrepetível desta experiência e verdade. Constitui-se assim um corpo - ambi-sexuado, cujo elo de apoio e vínculo é um enigmático $u$, de valor universal. Podemos pensar este corpo na figura do casal, sem que aí haja uma inferência jurídica ou legal a respeito. O casal está sempre na emergência da ilegalidade, um fora-da-lei, do mundo e da sociedade. O corpo assim constituído tem de ir além da sua condição de objeto universal ( $u$ ), que é por si mesma ilusória, falaciosa. Mas o que seriam estas posições?

${ }^{138}$ Cf. BADIOU, Logic of the worlds, p. 73-4, 2009 


\subsection{A posição homem}

A posição axiomática homem, para Badiou, ocupa-se de combinar duas funções no amor: a função imperativa e a função imobilidade ${ }^{139}$. A imperativa, para a posição homem, trata da continuidade desta verdade, dos procedimentos necessários ao trabalho para se perseverar no amor. Vislumbra-se aqui também a capacidade de construção de uma longevidade para as posições. Cabe ao homem, mesmo que na ausência, lutar pela presença do amor, algo de conceitual deve ser sempre sentido, mantido, independente da presença da outra posição.

A função imobilidade detém a nominação primeira do acontecimento: cabe a ela zelar pela não deglutição do encontro amoroso pelo acontecimento. Nada pode ser maior que o acontecimento, mas essa ideia não pode ser maior que a apresentação mesma dos amantes.

Há uma possível inanição na posição homem: que pode simplesmente nada fazer para e por amor, suspensa entre o não movimento e a falta de transgressão. A ela basta a certeza de sua existência, perdura-lhe o encantamento original do acontecimento, da promessa para todo o sempre. A fidelidade ao acontecimento é a sua palavra de ordem.

A posição homem é muda e pode também ser violenta, taciturna e lunar. Nada nela é capaz de algo aprender sobre a posição mulher. Não há pedagogia amorosa que faça esta posição se especializar e versar sobre a posição mulher. A questão para as duas posições é sempre sobre a verdade mesma do amor: o que sobre esta verdade as posições podem aprender e criar, disjuntamente?

Os juízos verídicos sobre o Dois, nas duas posições, não podem de maneira alguma coincidir. $\mathrm{O}$ acontecimento é o que força desde sempre a disjunção sexual mesmo se as posições não se ignoram. A posição homem, desde a sua primeira hora, trata da imobilidade do Dois - do nada genérico no vazio do Dois. Há nesta posição uma consciência prévia sobre a ontologia do amor: a disjunção lhe é inerente desde

${ }^{139}$ Cf. BADIOU, Conditions, p. 267, 1992 
sempre, independe do Dois para tomar-lhe a consciência. Ela a tem no seu ser, como premissa para o acontecimento do amor.

Sua postura é lógica, numérica, em oposição à posição ontológica mulher. Existe no homem a capacidade de análise da cada verdade na sua condicionalidade ao contexto do universal, percebendo as transversalidades possíveis entre os procedimentos genéricos. O homem atesta também o lado hétero-sexual ${ }^{140}$ da verdade do amor - estamos sempre na hetereidade, na diferença, segundo Badiou, no amor (há que se pensar o sexo, em contrapartida, como homo-sexual: a prática do mesmo e por si mesmo - naquilo que há de não-relacionante do corpo e de sua relação com o prazer).

Cabe a posição homem o acesso ao simbólico do todo, ao $H$ de humanidade $^{141}$, garantindo à posição mulher a certeza da irrefutabilidade do amor, conduzindo-a ao seu quantificador universal. É a posição homem que dissemina as virtualidades do contar-por-um da humanidade.

\subsection{A posição mulher}

A posição axiomática mulher, para Badiou, possui duas funções no amor: a função errante e a função relato. A primeira trata do acaso, do azar e da sorte no amor. É um jogar de dados com a vida que se renova e reinstaura na viagem do Dois, rumo ao infinito das possibilidades dos amantes. O Dois para a posição mulher é uma suposição, uma nuvem de verdade na apresentação do horizonte infinito do mundo. A segunda trata de um diário de bordo, uma inscrição em pedra nos arquivos da vivência amorosa, que se instaura no devir da errância do Dois.

A posição mulher é a da viagem do amor, das mil e uma noites de estórias no pensamento e nas trilhas do corpo. O desejo de sua palavra pede renovação e

\footnotetext{
${ }^{140}$ Cf. BADIOU, Conditions, p. 271, 1992

${ }^{141}$ Idem, p. 273
} 
inovação, busca novos amanhãs e horizontes. Em oposição direta à posição homem, é solar e falante, errante pela paz nos diálogos sobre a potência de verdade do amor. Para esta posição só existe o Dois do amor, só e tão somente "rien que le deux" ${ }^{142}$.

Há uma visão posterior sobre o dois nesta posição. Se antes ela creu na possibilidade do um, somente depois do acontecimento do amor que a disjunção se faz real para ela, fazendo-a rever seu conceito anterior. Esta posição se dá toda ao amor, só pensa no amor, é um ser-para-o-amor ${ }^{143}$. Sua condição irrevogável de dedicação não é proporcional à consciência do seu amor.

O valor da humanidade $H$ está relacionado à existência do amor para esta posição. Sua psicologia está atrelada à administração deste amor na sua transversalidade com as outras verdades. Não há como subtrair o amor dos outros procedimentos genéricos, seria o fim da posição mulher. Todas as verdades perderiam com isso. Esta posição exige neste processo a garantia de universalidade do amor e de outras disjunções possíveis, já que para esta posição nada indica haver somente uma possível no processo.

Conclui Badiou que o amor, $x$, como númeno, é o operador fiel que humaniza $H$. É o que permanece suspenso na indiferença de todos seus predicados, valendo para o todo do corpo da história. O casal seria uma metonímia do todo do mundo, que tem seu processo centrado no coração da disjunção pelas posições $h$ e $f$ :

Isso esclarece simplesmente que estes termos $\mathrm{x}$, as variáveis numênicas da função de Humanidade, compõem uma classe homogênea, que não se submete a nenhuma outra divisão que aquelas que induzem as ativações subjetivas iniciadas pelo acontecimento e pensamentos a partir de um procedimento fiel. ${ }^{144}$

O amor é esta verdade material na horizontalidade das relações individuais, um processo que leva o indivíduo ao incompatível do outro, ao não relacional do outro. Uma ação de um pensamento que se afilia na imanência ao verdadeiro da

\footnotetext{
${ }^{142}$ Cf. BADIOU, Conditions, p. 269, 1992, tradução: nada além do dois.

${ }^{143}$ Idem, p. 270

${ }^{144}$ Cf. BADIOU, Conditions, p. 260, 1992
} 
condição do homem e da humanidade. Mas para se chegar a uma ideia mais clara desta situação, há que se ver agora como os conceitos de acontecimento, subjetividade e fidelidade se apresentam na construção deste processo.

\section{Amor e acontecimento}

Citando o autor:

A alegria, finalmente, está do lado das palavras. Alegrar-se é alegrar-se com o fato de que haja tão poucas palavras para dizer o que há a dizer. (...) Daí que, na representação da declaração de amor, não há nada a dizer a não ser o "eu te amo", o que é extremamente pobre, porque está no elemento da alegria. ${ }^{145}$

A importância da declaração é inversamente proporcional à sua riqueza de construção para o autor. É através dela que se dá a quebra do ser do múltiplo, que se reestrutura a partir do entrelaçamento amoroso, no início do processo da identificação das partes disjuntas.

Se o amor começa pelo encontro, é na concretude do eu te amo que o jogo de sorte e azar faz a sua aposta inicial na sua duração e eternidade. O processo é misterioso e incerto, o que só fragiliza a sua construção:

Ou é justamente por isso que devemos preservá-lo: um acontecimento de aparência insignificante, mas que na realidade é um evento tão radical da vida microscópica, e portador, na sua obstinação e duração, de uma significação universal. ${ }^{146}$

O risco do vazio desta declaração é sempre eminente, pode fazer abortar no horizonte dos tempos a ideia da ideia do amor, dos amores passados, dos amores vindouros. Há uma passagem da aposta ao prêmio, do acaso ao caso maior de dois

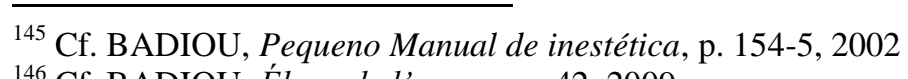

${ }^{146}$ Cf. BADIOU, Éloge de l'amour, p. 42, 2009 
destinos. Há que ser claro e distinto o acontecimento do amor. Não há acho, é possível, talvez, "seria o caso": é um ostinato cantábile que se instaura na fidelidade obsessiva a uma nova perspectiva de mundo, visto pelo olhar da eternidade desta verdade.

O acontecimento está no seu desaparecimento, no eclipse de uma situação que só existe no eco conceitual do eu te amo, tirado do vazio do sítio do contar-por-um da figura que se estabelece a partir deste instante: a do casal. O eu cola-se ao te que se transfigura em si mesmo, na sua diferença, ao se pronunciar pelo e através do amo. Aí se instaura a disjunção entre o $u m$ e o dois, onde o segundo termo fratura o primeiro:

Existe aí um esquema numérico próprio ao procedimento amoroso. Este esquema anuncia que o Dois fratura o Um e atesta a situação. Um, Dois e o infinito: esta é a numericidade do procedimento amoroso. Ela estrutura o devir de uma verdade genérica. Verdade de quê? Verdade de uma situação enquanto existam duas posições disjuntas. ${ }^{147}$

Peter Hallward não vê a declaração do acontecimento como real. Para ele somente o acontecimento se ancora na realidade. O enunciado eu te amo é frágil, ilógico, sem poder deslanchar uma revolução na evolução de dois indivíduos. Será a partir desta implicação lógica entre duas pessoas que se dá lentamente o desenrolar ilógico da coisa amor, uma consciência a posteriori de que o amor está presente nestas duas vidas que dividem uma declaração de afeto ${ }^{148}$.

Jason Barker parece concordar com a posição de Hallward sobre a questão. Se há questões sobre o acontecimento, elas estão no retroativo da análise, no futuro anterior da situação ${ }^{149}$. O eu te amo é ainda parte indizível do evento, ainda nos termos do genérico, nos termos e acordos da declaração do amor - e não no amor

\footnotetext{
${ }^{147}$ Cf. BADIOU, Conditions, p. 264, 1992

${ }^{148}$ Cf. HALLWARD, Badiou a subject to truth, p. 125, 2003

${ }^{149}$ Cf. BARKER, Alain Badiou a critical introduction, p. 105, 2002
} 
que se declara - ainda dentro de uma situação neutra, no processo de estabelecimento de um sítio ${ }^{150}$ para o ser do evento.

O acontecimento no amor é o ponto de ruptura no ser dos múltiplos em questão. Se há o ser do amor que se instaura neste momento, isso também nos permite pensar no ser do evento, nesta ruptura ontológica que se dá entre duas multiplicidades genéricas. Nas palavras de Badiou, estamos no trans-ser $^{151}$, na quebra ontológica da lei das multiplicidades. Ainda não o amor, ainda não o acontecimento, mas um encontro, uma noção de distância entre duas instâncias múltiplas e heterogêneas. No amor, esta distorção como trans-ser está no aleatório do acontecimento, no encontro de indivíduos que preconizam o ser de suas verdades que se dará num terreno de eternidade móvel, que enlaçarão dois tempos divergentes no surgimento de um infinito de possibilidades a partir do amor.

\section{Amor e sujeito}

Pensarmos o sujeito badiouniano em relação ao amor é pensarmos na produção de sentido e consequências entre dois indivíduos ( $x$ e $y$ ) que possuam uma relação ao espaço do Dois, seguindo suas condições de incompatibilidade e diferença $^{152}$. O sujeito no amor não ultrapassa e nem é comensurável ${ }^{153}$ à sua verdade: como configuração local do acontecimento, ele é finito, temporal, mesmo que se remeta ao infinito do amor. A sua existência se confirma localmente, a partir de sua crença naquilo que lhe dá vida e forma: a sua verdade existe, é determinação infinita de um indiscernível da situação do Dois.

\footnotetext{
${ }^{150}$ Sítio refere-se às condições de um acontecimento, refere-se ao tipo local de uma multiplicidade "concernida" por um evento; cf. BADIOU, O ser e o evento, p. 147, 1996

${ }^{151}$ Cf. BADIOU, Breve tratado de ontologia transitória, p. 59, 1998

${ }^{152}$ Cf. BADIOU, Théorie axiomatique du sujet, Seminaire d'Alain Badiou (1996-98), p. 3, em http://www.entretemps.asso.fr/Badiou/seminaire.htm

${ }^{153}$ Cf. BADIOU, O ser e o evento, p. 310, 1996
} 
O sujeito é produção de sentido: espera-se aqui que algo se crie, transforme, engaje os envolvidos numa arquitetura da diferença dos afetos. O sujeito é o Dois contado a partir de um terceiro, dependendo deste para vir a ser como representação do amor ${ }^{154}$.

Os sujeitos do amor devem sempre se perguntar: o amor ainda está aqui? O casal é o sujeito do amor para Badiou. Esta figura instaura-se na fidelidade ao procedimento ontológico subjetivo em questão: o sujeito não é um sujeito que ama ou um sujeito que é amado. Não é nenhum dos dois. Se afirmarmos isso, diremos que existem dois sujeitos, que o amor é uma relação, uma interação de subjetividades. $\mathrm{O}$ amor em questão é produção de subjetividade, o sujeito é produzido pelo amor. O casal se consubstancia em dois corpos, mas o espaço possível reduz-se ao de um casal. Nele se potencializa o amor, agindo sobre $x$ e $y$, de maneira diferenciada como um sentimento, um teste, uma prova. "O sujeito do amor está no devir do casal, não na satisfação pessoal dos indivíduos que o compõem","155.

Jason Barker destaca alguns aspectos na elaboração do sujeito na obra de Badiou:

1. O sujeito não serve a interesses particulares - por isso mesmo está fora de todos os critérios da objetividade - e está a serviço da longevidade de sua verdade, indiferente às regras e critérios locais de seu genérico (aí está o lado transgressivo, questionador e criativo do amor);

2. O sujeito apoia a verdade no seu futuro anterior, naquilo que há de indiscernível no seu acontecimento bem como na ausência de limites do vazio de sua verdade; o que atesta sua eternidade e infinitude;

3. O sujeito deve tomar uma posição em relação à verdade, seja ela qual for ${ }^{156}$.

Os amantes entram no amor na composição de um sujeito, que os exceda e transforme. Este sujeito se mantém pela sua própria prescrição, refletindo sempre o status real de sua situação e intensidade perante sua verdade: o amor é um salto

\footnotetext{
${ }^{154}$ Cf. BADIOU, Condiciones, p. 249, 2003

${ }^{155}$ Cf. BADIOU, Éloge de l'amour, p. 76, 2009

${ }^{156}$ Cf. BARKER, Alain Badiou a critical introduction, p. 108-9, 2002
} 
ao abismo, de olhos vendados, num ato de fé que atesta que a sua conversão foi completa, que a experiência do amor se representa na relação livre e autônoma com todas práticas e formas prévias, na afirmação de sua autonomia e diferença. O sujeito do amor é o real finito da situação, ao mesmo tempo em que é também uma nomeação que parece se esboçar na possibilidade de uma reinvenção de si possível e imaginável: "Um sujeito é assim, pela graças dos nomes, ao mesmo tempo o real do procedimento (o investigando das investigações) e a hipótese daquilo que seu inacabável resultado introduziria de novidade na apresentação". ${ }^{157}$

\subsection{Os três sujeitos possíveis do amor}

Badiou vislumbra três possibilidades de sujeito para o amor ${ }^{158}$. O primeiro seria do tipo fiel. Este sujeito do amor é uma "coletividade mínima"159, convocada para ser fiel na potência efetiva do Dois que o institui. Cabe a este sujeito transpor todas as falsas materialidades do amor, do narcisismo e do desejo para atingir a sua universalidade transindividual. O sujeito é essa emancipação do indivíduo para além de si mesmo, a forma "elementar de sublimação da singularidade em universalidade" ${ }^{\prime 60}$. Este sujeito é que eleva o indivíduo ao entendimento do nós no amor. Não como ontologia ou identidade, mas como construção daquilo que se passa a duas pessoas imersas no real da coisa. O sujeito fiel traz consigo o passe-livre para o infinito futuro do tempo do amor. Um gosto de eternidade no átomo universal local dos amantes.

O segundo sujeito seria do tipo reativo ${ }^{161}$. Este precisa de garantias para afirmarse na consolidação de sua formalização. Ele precisa de contrato, oficial, na

\footnotetext{
${ }^{157}$ Cf. BADIOU, O ser e o evento, p. 313, 1996

${ }^{158}$ Cf. BADIOU, Segundo manifesto por la filosofia, p. 106-111, 2010

${ }^{159}$ Idem, p. 106

${ }^{160}$ Idem, p. 107

${ }^{161}$ Idem, p. 108
} 
estipulação de um número certo de vantagens e promessas. Materializa-se facilmente em casa, família, conta bancária. Conjugalidade é a sua palavra de ordem, em contraponto formal a tudo aquilo de selvagem e errático que pode o amor proporcionar. Sua intensidade é medida, calculada e ajustada: para não muito desajustar. $\mathrm{O}$ amor aqui tem seus dias contados: a família $^{162}$ será o adendo contratual por excelência às regras iniciais. Fica no ar, para mim, a questão: adendo ou óbito?

A rotina é a sua marca, imprime neste sujeito suas cores primárias, criando a doce ilusão de cores em semanas monocromáticas e gagas (um quadro de uma só cor e som). Monocórdio e minimalista, soa como uma sinfonia de uma só nota, uma orquestra a duas vozes surdas, que se repetem ao infinito. Como conciliar a aventura criativa do Dois no protocolar institucional formal do três, do quatro da família? Esse amor quer garantia, passaporte e conduto ao mesmo do amor.

Nas palavras de Badiou: "Neste sentido, a conjugalidade é o amor sem amor. Seu objetivo é o de preservar a família nuclear moderna" ${ }^{\text {163. }}$.

O terceiro e último sujeito é o obscuro, que, como na política, traz nas suas veias a prática da militância, do armar-se para o desarmar-se de toda forma e fôrma. O amor é uma aventura, desesperada, na busca de uma adrenalina dos afetos que se reinvente a cada esquina e dia. Não há seguranças nem laços formais: a infidelidade ao Dois lhe é contingente. Este sujeito tem seus passos guiados pelos astros, cartas e búzios, por um $U m$ onipresente que lhe assegura o seu ofício nos afetos da ficção criada e recontada a si mesmo. Tudo é um grande conto, um atalho e participação nas estórias do $U m$ fusional.

O ciúme é também sua marca. Transforma sua vida social num thriller policial grotesco. Pelo ciúme é capaz de tudo. É o corpo que guia a sua escrita torta e vesga, perdido nas imperfeições que só o olhar pode assumir e projetar. Um exercício de tortura constante para as duas posições do amor, o ciúme procura o seu real

${ }^{162}$ Cf. BADIOU, Éloge de l'amour, p. 63, onde o amor aparece como um procedimento de verdade desinteressado, a partir dos interesses imediatos da subjetividade amorosa do casal, sem desdobramentos em família e conjugalidades.

${ }^{163}$ Cf. BADIOU, Segundo manifesto por la filosofia, p. 109 
simbólico: a morte! O assassinato por este sujeito não é uma impossibilidade. "Entre a família indistinta e os céus mortíferos, o amor deve sustentar a aposta de sua eternidade móvel" ${ }^{164}$.

\section{Amor e fidelidade}

Nada nos é prometido, apenas ser fiel ao que nos acontece. $^{165}$

Badiou parece pensar a questão da fidelidade (primeiramente elaborada a partir da eclosão de um acontecimento) no seu projeto filosófico levando em conta o amor. É o que parece atestar a sua introdução de $O$ Ser e o Evento. As duas fidelidades (a sua e a do casamento) se intercruzam incestuosamente, já que ambas são normalmente consideradas em íntima conexão e relação. A fidelidade aqui em questão é um acordo a partir do amor. Será a partir da experiência individual amorosa que esta dialética parece se estruturar:

A palavra "fidelidade" remete nitidamente à relação amorosa, mas eu diria que é antes a relação amorosa que remete, no ponto mais sensível da experiência individual, à dialética do ser e do evento, da qual a fidelidade propõe uma ordenação temporal. De fato, é indubitável que o amor se chama amor, se funda numa intervenção - e, portanto, numa nomeação, nas paragens de um vazio convocado pelo encontro. ${ }^{166}$

A fidelidade é o que evidencia, nos múltiplos apresentados, aqueles que interagem ativamente no evento na sua ordenação temporal e numérica. Longe de representar as questões morais de virtude e monogamia, a fidelidade em questão nos

\footnotetext{
${ }^{164}$ Idem, p. 111

${ }^{165}$ Cf. BADIOU, Breve tratado de ontologia transitória, p. 24, 1998

${ }^{166}$ Cf. BADIOU, O ser e o evento, p. 188, 1996
} 
faz pensar ao ideário do Dois, uma operação examinadora entre o funcional prático do acontecimento e suas consequências.

Toda fidelidade no amor é particular ${ }^{167}$, só que sem critérios. Seus resultados e conexões possíveis são também aleatórios, formados pelas circunstâncias a partir de como o sujeito reincorpora o acontecimento ao procedimento genérico em questão. Há algo de institucional na fidelidade, conectando e desconectando elementos, criando novas camadas de legitimações possíveis, segundo Bruno Besana ${ }^{168}$. Ele identifica um aspecto analítico na questão entre aqueles envolvidos num acontecimento. Existem pontos identificados por Besana que são desligados ou reconectados ao acontecimento através da fidelidade, como dispositivos de verificação ligados ao infinito dos múltiplos envolvidos e dependentes ao processo.

A fidelidade no amor é o compromisso em se construir uma duração ${ }^{169}$ que vença as idiossincrasias da vida, alheia às agruras dos jogos de sorte e azar. "Porque no fim das contas, é isso o amor: uma declaração de eternidade que deve se realizar ou se desenvolver, como possível, no tempo" ${ }^{\text {170. }}$.

\section{5. $O$ amor, a verdade e a ideia}

A filosofia para Badiou é o lugar para a identificação, debate e apreço pelas verdades. Cabe à filosofia a tarefa de pinçar no mundo das opiniões o imaterial vazio da verdade. Há que se identificá-la tanto a partir de discussões e produções acadêmicas, no frescor dos movimentos políticos, quanto na produção poética, mas ainda, e em especial, a partir da esfera subjetiva. O amor é a grande prova de subjetividade filosófica, a dilatação de uma finitude elevada a uma dimensão simbólica infinita.

\footnotetext{
${ }^{167}$ Cf. BADIOU, O ser e o evento, p. 189, 1996

${ }^{168}$ Cf. BESANA, Alain Badiou, key concepts, p. 44, 2010

${ }^{169}$ Cf. BADIOU, Éloge de l'amour, p.44, 2009

${ }^{170}$ Cf. BADIOU, Éloge de l'amour, p.45, 2009
} 
A verdade no amor é um furo, um ponto insituável, indiscernível nos anais de toda enciclopédia. Não existe a não-verdade no amor. O seu falso é o seu fim, o que impede a sua continuação. O seu inverídico e contrário, o seu errôneo: não é amor. $\mathrm{O}$ amor corrompe, para todo o sempre, o indivíduo pelo Dois. Uma pedagogia negativa, que deseduca o homem nos caminhos dos afetos de superfície. A parte e o todo: um perder-se na suspensão entre a verdade do amor e o amor da verdade individual, inserida na existência de um indivíduo ${ }^{171}$. É o incorporar-se de um sujeito num procedimento de verdade: "a verdadeira vida na vida da verdade" ${ }^{172}$. É a vida vista e medida a partir de outra situação que se refaz ininterruptamente pela potência que se instaura num sujeito. Há aí um misto de crença e entrega, uma identificação ao real do imaginário amoroso que se desenvolve no interior deste processo.

Este imaginário se cria pela incorporação da verdadeira vida na vida da verdade, que se dá no devir desta, na sua incorporação lenta e progressiva cujo objetivo é uma construção orientadora, no estabelecimento de outros pontos cardeais que não norte e o sul, já que sem direção precisa, sem ponto de chegada ou limite. Não há objetividade no amor, ele não parte de um princípio prático, não possui um objeto preciso. O que há é o desnorteio conceitual do indivíduo, que se refaz pela visão de mundo a partir do Dois.

É o real do ato, pensamento e afeto a partir do amor mesmo: é a representação imaginária que dilata o sujeito a uma dimensão infinita que o leva ao cerne mesmo do amor, que o entorpece e desgoverna de sua finitude, elevando-o ao universal do mundo. Esclarece o autor:

(...) de certa maneira é evidentemente no imaginário que isso acontece, já que você não está numa escala mundial da história, você está simplesmente numa localização incorporada a algo apenas imaginado, ou representado, como que sendo levado ao infinito mesmo que isso aconteça numa reunião entre quatro pessoas. $\mathrm{E}$ isso não é uma ilusão, eu insisto, isso é simplesmente a atestação

\footnotetext{
${ }^{171}$ Cf. HALLWARD, Badiou a subject to truth, p.181, 2003

${ }^{172}$ Cf. BADIOU, Pour aujourd'hui: Platon!(3) - Seminaire Alain Badiou, p. 10, de 28 de Outubro de 2009, em http://www.entretemps.asso.fr/Badiou/seminaire.htm
} 
imaginária da incorporação. Mas a atestação imaginária desta incorporação não deve ser considerada como falsa ou ilusória, etc, já que na realidade, no final das contas, o procedimento é feito disso, nada além disso! $!^{173}$

Existe um aspecto convulsivo no amor, extremamente forte e impulsivo, que leva o sujeito como que num transe, que o faz perder-se num excesso de si mesmo, em tantas direções, que acontece a partir do interno desta incorporação imaginária. $\mathrm{O}$ material do amor é feito a partir desta ideia, incorporável, no interior do sujeito, que o joga neste real do imaginário: "Há então uma verdade deste imaginário, que é precisamente um imaginário da verdade mesma, que é uma representação totalizante da verdade; e é isso que constitui esta verdade do imaginário"174.

Badiou irá chamar de ideia o processo de integração individual a este imaginário amoroso, que para ele se dá ainda em duas outras instâncias: a dimensão real do procedimento de verdade (a sua exceção material local) e a dimensão simbólica (a coisa do amor como representação). A ideia é o que organiza estas três dimensões na sua incorporação subjetiva pelo casal, que a partir do real de sua verdade, fragmentária e precária, vislumbra este momento de exceção global que sua verdade constitui. A ideia trabalha o seu aspecto simbólico naquilo que ela espontaneamente cria e descobre, no futuro anterior de sua dimensão local, já que há neste quesito somente uma temporalidade presente, no simbolismo imediato da representação de sua condição que se reinventa e descobre a partir do amor.

A ideia é a capacidade de integração do casal ao Dois, do Dois ao universal do amor; é ela que articula a territorialidade e o alcance da subjetividade amorosa ou quando o sujeito se sente incorporado, nele mesmo, pela subjetividade amorosa ${ }^{175}$. A ideia permeia as diversas dimensões do casal - mesmo a dimensão totalizante e imaginária de sua expansão e alcance global estão a seu serviço. A ideia também está

\footnotetext{
${ }^{173}$ Cf. BADIOU, Pour aujourd'hui: Platon!(3) - Seminaire Alain Badiou, p. 11, de 28 de Outubro de 2009, em http://www.entretemps.asso.fr/Badiou/seminaire.htm ${ }^{174}$ Idem

${ }^{175}$ Cf. BADIOU, Pour aujourd'hui: Platon!(3) - Seminaire Alain Badiou, p. 13, de 28 de Outubro de 2009, em http://www.entretemps.asso.fr/Badiou/seminaire.htm
} 
no simbólico, no regime de exceção que se instaura no descortinar da rotina amorosa. Nas palavras de Badiou:

(...) é a ideia que fazemos daquilo que fazemos, que integra os parâmetros reais, simbólicos e imaginários daquilo que fazemos é quando se está nesta Ideia que temos a verdadeira vida. É isso. Existe então a verdadeira vida como compositória da vida da verdade. (...) Consequentemente, a verdadeira vida é a vida segundo a Ideia. ${ }^{176}$

É a ideia que sintetiza e representa o procedimento de verdade para o sujeito do amor. Sua incorporação, seguindo os passos de Platão, configura uma ascese do local ao universal, de uma singularidade afetiva que se insere na generalidade do amor. Uma atividade, operatória e investigatória, que só existe a partir da concretude de seus passos e procedimentos. A verdade do amor se dá na conexão, pela ideia, ao vazio da verdade, induzindo os sujeitos envolvidos a se envolverem no procedimento.

A ideia é a garantia e proteção, uma muralha natural contra as intempéries desta cadeia de eventos do amor. A ideia é também um lugar, um território comunal ao Dois, uma nova ilha de utopia, que liga os sujeitos do amor ao simbólico, educando-os neste processo educativo (na pedagogia da passagem da sua representação ao seu simbólico) de sua verdade.

Nas palavras de Hallward: “(...) é então assim que uma verdade induz seus sujeitos a ela - e não ao contrário" ${ }^{177}$. A verdade são acumulações de pontos infinitos no seu interno, cujos sujeitos são representações finitas de sua marca de eternidade. Se a ideia é o que atualiza o sujeito na virtualidade de seus vínculos, Hallward ainda assim analisa a questão da verdade em Badiou como sendo uma construção a partir de atos e decisões - mais do que palavras e pensamentos. Se a ideia constrói o relacional conceitual do amor, será pela concretude da rotina do casal que se descortinará a real inserção destes na verdade. Hallward vê em especial a noção de suspensão temporal

\footnotetext{
176 Cf. BADIOU, Pour aujourd'hui: Platon!(3) - Seminaire Alain Badiou, p. 13, de 28 de Outubro de 2009, em http://www.entretemps.asso.fr/Badiou/seminaire.htm

${ }^{177}$ Cf. HALLWARD, Badiou, a subject to truth, p. 142, 2003
} 
como fundamental para se entender este pensamento em Badiou. Um eterno presente se cria a partir do amor, um tempo sem promessa, herança, reserva, completamente saturado pelo momento da coisa amor. O tempo é o pano de fundo para que se descortine o amor como forma no espaço, o que enquadra o real do processo da verdade. Se há uma verdade, o tempo é o há do enunciado, o seu suporte existencial que se inscreve na sucessividade vazia da verdade, na anterioridade futura de sua infinitude, no reinventar do seu reinventar - o que retira o homem de sua morte, abrindo-o à onipresença de seu infinito possível.

O amor? Um instante: um exercício do afeto no pensamento pontual da ideia, infinita, de um ser-finito. 


\section{Capítulo III: A Reinvenção}

\section{O homem hoje e a sua reinvenção}

Como reinventar o amor? Quais os procedimentos para se lançar o pensamento na recriação da experiência subjetiva amorosa, descontruindo os passos relacionais que estratificam o outro ao outro, nas busca de novos critérios que escapem da armadilha identitária e que acolham o surgir imediato da diferença no seu frescor inaugural e espontâneo? Uma tarefa por vezes cega, manca, especialmente se levarmos em conta a dinâmica acelerada das relações no mundo de hoje. O homem contemporâneo encontra-se saturado pelo culto narcísico à imagem, em que prazer e sexualidade se transformaram em ingredientes baratos e acessíveis a uma criação virtual compartilhável de felicidade e realização. O materialismo capitalista do século XX finalmente se decidiu por uma abertura a outros mercados, possibilitando a ideia

de que outros núcleos afetivos (que não aqueles da heteronormatividade) se reinventem e afirmem (como bem demostra a legalização e legitimação das relações homoafetivas ao redor do mundo, inclusive aqui, no Brasil).

O grande desafio, proposto por Badiou, é o de nos elevarmos do mar da mesmice do pensamento sobre o amor, indo ao resgate de éros nas relações de maneira inusitada e criativa. Pensarmos o homem na inserção do novo e da reinvenção implica um ato de coragem, audácia de enunciado, revirando as noções construídas pelo nosso pretérito recente, retirando-nos de nossa aposentadoria conceitual na reformulação de opiniões e escolhas. Despir o homem de hoje de sua moral e virtude e clamar pela insurgência de seu espontâneo, ainda mudo e silencioso, no frescor do seu desejo e afeto, é tarefa da filosofia. Michel Foucault nos convida a esta aventura:

Para o pensamento moderno não há moral possível; desde o século XIX o pensamento já "saiu” de si mesmo em seu ser próprio, ele não é mais teoria; a partir do momento que ele se pensa, ele fere 
ou reconcilia, aproxima ou separa, ele rompe, ele dissocia, ele ata e desata, ele não pode se impedir de libertar e escravizar. Antes mesmo de prescrever, esboçar um futuro, dizer o que deva ser feito, antes mesmo de encorajar ou simplesmente alertar, o pensamento, na raiz de sua existência, desde a sua forma mais matinal, é, nele mesmo, já uma ação - um ato perigoso. ${ }^{178}$

Se Badiou nos lança na tarefa da reinvenção da reinvenção do amor, cabe agora, seguindo as indicações de Foucault, abrirmos o pensamento para desarticularmos o edifício estrutural dos afetos, tentando reconciliar o que há de aberto e desestruturado, logo livre, nos horizontes do código amoroso nos dias de hoje. Traduzir este murmúrio indefinido e jogá-lo no impensado do pensamento é o que pode ainda e sempre ativar novas transversalidades relacionais, definir novos atores no cenário dos afetos humanos. O perigo do pensar foucaultiano em questão é já convite à ação, à identificação da reinvenção que se orienta pelo que no horizonte se apresenta - ou que convida a orientar a partir daquilo que no seu interior se pensa.

Cabe levar a questão a outros pensadores da condição humana contemporânea, conjugando neurônios num mapeamento de uma radiografia fresca, imberbe e infantil, do horizonte das relações amorosas. Quais as possibilidades? Como reinventar o Dois? O que é hoje a sexualidade na construção dos afetos? Qual o cenário real da coisa amor hoje, para o homem? Como inscrever o amor, na sua lei de reinvenção, no microscópico de sua duração, numa possível jurisprudência de significação universal e eterna, no culto ao errático e estrangeiro do homem, uma ode ao abandono, sensualizando a experiência na sua condição fugaz e impermanente: "Aimez ce que vous ne verrez deux fois"- clama Badiou! ${ }^{179}$ Mas o cenário é bem outro, se seguimos os passos e análises de outros pensadores que se encontram dentro da análise das dinâmicas relacionais propostas pelos novos meios de tecnologia de hoje. Imersos num fluxo impessoal e interminável de informação, há um dissipar do próprio homem que se descortina neste processo.

\footnotetext{
${ }^{178}$ Cf. FOUCAULT, Michel Foucault Philosophie anthologie, p.272-3, 2005

${ }^{179}$ Cf. BADIOU, Éloge à l'amour, p. 83, 2009, trad.: Ame aquilo que você não verá duas vezes.
} 
Foucault previu a necessidade de se ampliar o espectro afetivo do homem, e em entrevista de 20.10.1981, assim analisava a situação:

Vivemos em um mundo relacional consideravelmente empobrecido pelas instituições. A sociedade e as instituições que constituem sua ossatura limitaram as possibilidades de relações, porque um mundo relacional rico seria extremamente complicado de administrar. Devemos lutar contra esse empobrecimento do tecido relacional. Devemos obter o reconhecimento das relações de coexistência provisória, de adoção... ${ }^{180}$

O autor, nas suas últimas entrevistas, lançou um horizonte de possibilidades e questionamentos para a questão do amor, amizade e afeto a partir dos relacionamentos gays, que para ele tinham o desejo (e a liberdade) como motor principal na criação de novas correspondências sociais. Sua proposta seria a de se reformularem os papéis afetivos a partir de uma sexualidade (e prazer) que escapasse do normativo da sexualidade. Passados mais de 30 anos, a citação acima parece lançar ainda um espectro conceitual fresco e inovador sobre a questão do amor. Resta saber se o cenário atual seria a moldura para este tipo de criação da arte de amar.

Nas palavras de Claudine Haroche:

Sob o impacto da globalização, as sociedades contemporâneas tendem a se tornar sociedades que se transformam de maneira contínua; sociedades flexíveis, sem fronteiras e sem limites; sociedades fluidas, líquidas. Tais condições têm consequências sobre os traços de personalidade, dos mais contingentes e superficiais aos mais profundos, sobre os tipos de personalidade que tendem a desenvolver e mesmo encorajar, e também sobre a natureza das relações entre os indivíduos. A fluidez destituída intrinsecamente de limites acarreta modificações nas estruturas e pode pôr em questão a possibilidade de estruturação e mesmo de existência do eu. É possível pensar imerso na fluidez, sob a pressão permanente e ininterrupta do fluxo? Privado de tempo, da

${ }^{180}$ Cf. FOUCAULT, Ditos e escritos V (Ética, sexualidade, política), p.120, 2010 
duração exigida pelos sentimentos, o indivíduo hipermoderno pode experimentar algo diferente das sensações ${ }^{181}$

A autora nos leva a pensar sobre os efeitos que a dinâmica relacional do mundo de hoje acarreta na qualidade das interações afetivas. Somos todos hoje reféns de um fluxo de acontecimentos que nos leva de volta à insensatez das bestas irracionais. Só que sem inocência. Encontramo-nos gélidos e anestesiados ao processo de interação e integração social. Há algo de estrutural, identificado pela autora, que vai além do mero fenômeno individual, mas algo compartilhado pela sociedade na sua apresentação real de nossa época. Nossos vínculos estão em outros termos de duração e fidelidade: não há mais aposta, só o interesse por ganhos a partir de critérios materiais e sensuais, nos condicionando a um sentir de superfície, ralo e brando, distante das transformações pensadas a partir do Dois do amor de Badiou.

O fluxo relacional nas sociedades de hoje carece de um ponto objetivo referencial, um elo ao constante de onde se possa vislumbrar o horizonte do mesmo, um ponto fixo de apoio para que o humano se desacelere e se defina. A autora questiona a própria noção de existência de um $e u$ referencial na questão, perdido pela falta de um ponto de fuga organizacional, que pudesse coordenar os diversos aspectos sensíveis da experiência. Se os únicos pontos de referência conhecidos são eles mesmos variáveis, como se estruturar a alteridade e a diferença a partir de um eu que se indefine num horizonte incessante de transformações? Nada parece durar, para Haroche, o suficiente, para que se estabeleça a necessidade de vínculos afetivos:

O movimento contínuo entrava a possibilidade de reflexão, a eventualidade de uma hesitação, a possibilidade de distanciamento, processos de elaboração das percepções baseados nas sensações. Dessa forma, a personalidade hipermoderna se caracteriza pela ausência de engajamento, com a qual o indivíduo está "ligado, porém

${ }^{181}$ Cf. HAROCHE, A condição sensível formas e maneiras de sentir no ocidente, p. 123, 2008 
distante". Ele experimenta "a necessidade da presença dos outros, mas afastado deles". ${ }^{182}$

Faltam-nos as formas conhecidas (e reconhecidas) de estabilidade e de fixidez, capazes de uma pedagogia que enquadre o indivíduo numa subjetividade emocional nova, refrescada. Há um processo de desgaste e enquadramento das relações nos meios virtuais, que liquidificam as relações, numa ausência de estreitamento afetivo. O que há é um enquadramento imagético, um texto cênico escrito para não ser lido, só visto, por olhos caducados pela falta de uma ciência das sensações reais do homem. O amor, por exemplo, parece se confundir com a capacidade mais superficial do sentir e gostar. Do curtir.

Existe um processo de alienação, para Haroche, que se cria a partir dos processos interativos de hoje, um excesso de visibilidade de si que exausta o indivíduo num exibicionismo crônico, causando uma perda de privacidade e território íntimo (terreno este necessário para o acolhimento do outro) ${ }^{183}$. Há uma função voyeur de si mesmo que se instaura, em que o grande prazer é o de ser visto, maquinalmente, num ritual onanístico do olhar. Está no duplicar do gozo do olhar a legitimidade da coisa:

A visibilidade seria sinônimo de legitimidade, de utilidade, garantia de qualidade: a quantidade, de fato e a continuidade da visibilidade valorizariam o indivíduo. A invisibilidade, por ela mesmo, seria sinônimo de inutilidade, de insignificância, de mesmo de inexistência. ${ }^{184}$

Há uma submissão pueril ao ritmo acelerado e frenético dos rituais opiniáticos e de gostos (curtidas) das redes sociais, criando na superfície dérmica do homem contemporâneo uma capa de proteção alumínica, alterando os rituais do sentir e do amar. Uma alienação psíquica se anuncia, segundo Haroche, no devir das relações ${ }^{185}$.

\footnotetext{
${ }^{182}$ Cf. HAROCHE, Claudine, A condição sensível formas e maneiras de sentir no ocidente, p. 128 , 2008

${ }^{183}$ Cf. HAROCHE, Le sentiment d'humiliation, p.28, 2006

${ }^{184}$ Idem

${ }^{185}$ Idem, p. 29
} 
A nossa própria capacidade de sentir e amar é hoje questionada: a base relacional é armada a partir da falta de confronto, tomamos medidas, impessoais, que nos posicionam em deslocamento constante, fluido, tornando o real do outro inacessível e indiscernível - já que igualmente composto de imagens virtualmente construídas.

Trata-se de uma estratégia de dominação (e criação) de si que implica a hesitação ao vínculo, que se furta também a capacidade mesmo de um autoconhecimento - já que a noção de estabilidade, necessária para isso aconteça, parece também estar ausente.

Como estabelecer o engajamento ao próximo se não há isso nem para consigo mesmo? O eu inconsiste no fluxo, inconsistindo o outro, consequentemente. As relações se efemerizam, não se inserem numa temporalidade eleita, pessoal, intransferível. Não há espaço para a ruptura, já que não há conflito nem permanência. Não há chance de construção simbólica, de uma fidelização do hoje, pois o amanhã nunca chega, já que é desconstruído pela ruptura contínua de um presente que se reinventa incessantemente.

Haroche nos relembra dos estudos de Zygmunt Bauman, que nos alertou para os laços frágeis estabelecidos na sociedade contemporânea, analisando o amor como líquido, no seu aspecto descartável e imaterial, ausentando o indivíduo de um comprometimento real com a identidade: "Todos estamos dentro do mercado, ao mesmo tempo clientes e mercadorias"186. O mercado é volátil e instável, oscila diariamente, se recicla estética, social e sexualmente ao sabor dos dias e modismos. A subjetividade virou um acessório material, real, comprável e adquirível. Ao alcance de todos. A autora vislumbra um cenário desolado e triste, na falta de engajamentos reais com processos de construção de verdade. Nas palavras de Bauman:

O que todos nós parecemos temer, quer estejamos ou não sofrendo de "depressão dependente", seja à luz do dia ou assombrados por alucinações noturnas, é o abandono, a exclusão, ser

${ }^{186}$ Cf. BAUMAN, Identidade, p. 98, 2005 
rejeitado, ser banido, ser repudiado, ser descartado, despido daquilo que se é, não ter permissão para ser o que se deseja ser. ${ }^{187}$

O abandono em questão é resultado direto da indiferenciação percebida por Haroche devido ao excesso de fluxos (de informação e de sensação) contínuos, construídos pela mídia numa difusão sem limites de imagens e conteúdos, que, em contraponto, desconstroem a percepção das qualidades de exceção do mundo. Há um aborto ao detalhe, ao fugidio, a tudo aquilo que escapa devido à incessante massificação de uma informação que se mostra alienante e superficial, que impede o indivíduo de uma real assimilação do outro, enfraquecendo-o. Só há compreensão na suspensão, na ataraxia voluntária para que o pensamento entre em ação, positivamente, reflexivamente, no saudável exercício do ir e vir, entre uma coisa e outra, na paragem de um tempo que só acontece no interno da reflexão. É aí onde o eu se estrutura, segundo Ravaisson: "Como medir este fluxo ininterrupto e difusão sem limites (...) senão por alguma coisa que não passe, mas que subsista e dure? E o que seria isso senão o eu?" 188

Ravaisson, segundo Haroche, vê esse eu desgastado, esgotado pela sua superexposição a esse excesso de informação (mas de pouca profundidade) que o acelera, continuamente, numa corrida em que não há chegada - só correr. Há algo nesta olimpíada midiática que anula o eu do indivíduo naquilo que ele tem de mais particular, e que por isso o enfraquece na projeção de seus afetos mais íntimos e genuínos: a sua capacidade de encantamento, de apaixonar-se por algo ou por alguém. Para o encantamento, o amor ou a paixão, é necessária a suspensão, a interrupção, o engajamento psicofísico.

Lidamos hoje com um infinito de sensações propostas pelas mídias; sensações estas interligadas num continuum mobile ad aeternum, na ilusão de serem quase como uma prolongação de si, como um outro membro que se instaura roboticamente no corpo:

\footnotetext{
${ }^{187}$ Idem, p. 99

${ }^{188}$ Cf. RAVAISSON, De l'habitude, p. 55, 1997, apud HAROCHE 2009: p.42
} 
As mídas permitem que se experimente, através das telas, um prolongamento de si e nisso reside um ponto fundamental exterior a si: a experiência, o fato de experimentar provocado pela estimulação, a excitação e constância de sensação progressivamente destituída de sentido ocupam o primeiro lugar, confrontando-nos consequentemente a novas experiências de vida e pensamento, de bem-estar, de mal-estar, talvez a novas maneiras de não sofrer (...). ${ }^{189}$

Novas maneiras de não sofrer e de não se envolver. Como reinventar o amor se não há envolvimento com o outro? Com a diferença do outro? Um dos grandes problemas está no avatarismo possível dos perfis amorosos criados na internet, que dá ao indivíduo plataformas de se recriar em diferentes manifestações possíveis, testando no outro os efeitos desta duplicação holográfica e teatral de si.

O cenário é pouco confortante, segundo o pensamento destes autores, para pensarmos a reinvenção da reinvenção do amor. Mas o desafio está aí, nesta área onde o pensamento se dobra sobre si mesmo, na criação e reconfiguração de novos jogos interacionais, escrevendo novos papéis e regras para novos atores sociais. Segundo Jean Baudrillard:

(...) a regra não precisa de nenhuma estrutura ou superestrutura formal, moral ou psicológica para funcionar. Justamente porque é arbitrária, infundada e sem referências, não precisa de consenso nem de vontade ou de uma verdade de grupo; ela existe, é tudo, e só existe partilhada $(. . .)^{190}$.

A regra no amor é intimamente associada àquilo que me atrai no outro, um continente que se abre no meu ser ao identificar no outro um oceano aberto ao descobrimento de novos continentes nele, o outro, e em mim também.

Existe sempre uma dimensão dentro de nós e em relação aos outros que não podemos precisar, e este não precisar persiste em nós como uma condição de existência. Somos, até certo ponto, atraídos pelo que não sabemos e pelo que não

\footnotetext{
${ }^{189}$ Cf. HAROCHE, Figurações do outro na história, p. 54, 2009

${ }^{190}$ Cf. BAUDRILLARD, Da sedução, p. 155, 2006
} 
podemos saber no outro. Não há amor sem invasão, sem intromissão em terreno alheio - e sem salvo conduto para que sejamos igualmente invadidos... Reinventar o amor requer uma aposta, igualmente, na aventura do reinventar-se - transformar-se naquilo que realmente somos e desejamos. Sermos, antes do amor, livres para amar:

A ontologia crítica de nós mesmo, devemos considerá-la não como uma teoria, uma doutrina, nem mesmo um corpo permanente de saber que se acumula; devemos concebê-la como uma atitude, um êthos, uma vida filosófica onde a crítica daquilo que somos é por vezes uma análise histórica dos limites que nos são impostos e testados nos seus cruzamentos possíveis (...). Eu não sei se se deve dizer hoje que o trabalho crítico implica ainda uma vez o das Luzes; é necessário, eu acredito, sempre, o trabalho sobre nossos limites, quero dizer, um labor paciente que venha a dar forma à impaciência pela liberdade. ${ }^{191}$

\section{Foucault: a reinvenção do desejo e do Dois}

Foucault concebe o desejo não como uma espécie de instrumento para a liberação do homem, mas como uma posição marginal estratégica, de onde novas formas de conhecimento e relação para si mesmo e com os outros podem ser pensadas. $\mathrm{O}$ autor, especialmente nas entrevistas e escritos de seus últimos anos de vida, identificou nos códigos de conduta dos gays práticas que poderiam estabelecer novas condutas éticas, que poderiam propor ao sujeito um estilo individual de vida único, intransferível, segundo sua própria concepção de vida, beleza ou virtude. Longe de ser uma prática intimista e individual, o autor vislumbrava aí um campo para uma intensa prática social, criando novas transversalidades relacionais:

\footnotetext{
${ }^{191}$ Cf. FOUCAULT, Michel Foucault Philosophie anthologie, p. 877, 2004
} 
A homossexualidade é uma ocasião histórica de se reabrir virtualidades relacionais e afetivas, não tanto pelas qualidades intrínsecas ao homossexual, mas porque a partir de sua posição em viés, de alguma maneira, linhas diagonais podem ser traçadas por ele no tecido social, permitindo fazer aparecer estas virtualidades. ${ }^{192}$

Há algo mais que uma simples atitude de escolha em questão. Algo de mais genuíno, a ver com aquilo que se dá no sujeito, e só no sujeito: o seu desejo mesmo. Sua capacidade de se constituir afetivamente a partir desta ascese e completude da verdade de sua paixão e sexualidade. Não há verdade no sexo para Foucault, não é essa a questão. Trata aqui o autor das formas relacionais diagonais, a partir do sexo e do desejo, que se inscrevem numa nova subjetividade, mais real e digna, coerente com as regras do indivíduo - e não da sociedade. David Halperin, analisando o pensamento de Foucault sobre a questão, chega a vislumbrar, neste exercício, "novas formas de relação entre os indivíduos, novas formas de conhecimento, novos meios criativos, novas possibilidades de amor." 193

Foucault vê na condição gay ${ }^{194}$ um estilo de vida num tempo que advirá, numa extemporaneidade aberta ao experimento e à criação:

Estas escolhas sexuais devem ser ao mesmo tempo criadoras de um modo de vida. Ser gay significa que estas escolhas se difundem através de toda a vida, sendo também uma maneira de se recusar os modelos de vida até então propostos, é fazer a escolha sexual como um operador duma mudança de existência. ${ }^{195}$

A condição gay não é para Foucault algo a ver só com o desejo, mas com o desejável, com a abertura a uma certa noção livre e espontânea na criação de uma identidade sempre em aberto. Uma potência à diferença pelo exercício pleno do seu

\footnotetext{
${ }^{192}$ Cf. FOUCAULT, Dits et écrits IV, p.166, apud HALPERIN 2000: p.81

${ }^{193}$ Cf. HALPERIN, Saint Foucault, p. 91, 2000

${ }^{194}$ Foucault faz uma nítida distinção entre a condição gay (livre e aberta) e a homossexual (codificada por relações de poder e controle), onde a primeira convida o indivíduo e a sociedade a um livre exercício de seu desejo e sexualidade, e a segunda, sujeita aos critérios de um código medicinal e social a partir da heteronormatividade.

${ }^{195}$ Cf. FOUCAULT, Dits et écrits IV, p.295, apud HALPERIN 2000: p.90
} 
desejo, numa reconfiguração possível das figuras formais do amor e da amizade, que poderia reconfigurar o todo da sociedade.

Badiou tem no cerne de sua filosofia sobre o amor a figura do Dois, onde o casal é o seu grande ator subjetivo, o que se apresenta ao mundo como figura simbólica do amor. Foucault, em entrevista à revista francesa Gai Pied, sem querer contestar ou negar o que está em vigor na norma relacional afetiva, convida o pensamento na construção de novos polos relacionais possíveis ao analisar o casal homossexual masculino:

Desde que eu me lembre, ter vontade de ter rapazes, quer dizer ter vontade de ter relações com rapazes. Isso sempre foi para mim algo de importante. Não simplesmente na figura do casal, mas como uma questão de existência: como é possível para os homens ficarem juntos, viverem juntos, dividirem seu tempo, refeição, quarto, prazeres, tristezas, saberes, confidências? O que é isso, estar entre homens, $n u$, fora de toda institucionalidade relacional, da família, da profissão, das obrigações de camaradagem? ${ }^{196}$

Uma relação aberta à reinvenção, a uma pesquisa fora dos parâmetros de constituição de família era o que propunha Foucault. Liberar o indivíduo do institucional social, livrá-lo de uma sociedade que o engessa em formas tradicionais. A abertura à ventura de que nos fala autor, hoje, encontra-se formalizada através das relações estáveis (como também o casamento) para os casais homoafetivos, na reduplicação de soluções sociais prévias, numa adoção de vestimentas prét-à-porter numa coleção que deveria ser, por força, haute-coûture - avanguardista e nãoduplicável. Vivemos num mundo onde o regulamento social formal dá poucas chances ao indivíduo de reinventar-se, já que todas as variantes sobre o tema, hoje, existentes, são extremamente esquematizadas e pobres, enquadradas nos conformes de uma família (ou o amor sem amor, segundo Badiou) ou da parentalidade e da adoção. Foucault também propõe algo sobre o tema:

196 Cf. FOUCAULT, Dits et écrits IV, p.163-4, apud HALPERIN 2000: p.93 
Devemos tentar conseguir que as relações provisórias existentes sejam reconhecidas como adoção, eu afirmo. Por que eu não adotaria um amigo vinte anos mais jovem? E mesmo um de dez anos a mais? Mais que fazer valer que os indivíduos tenham o mesmo direitos fundamentais e naturais, deveríamos tentar imaginar e criar um novo direito relacional que permitiria que todos os tipos possíveis de relações pudessem existir sem serem impedidos, bloqueados ou anulados por instituições empobrecedoras. ${ }^{197}$

Halperin vê aí uma tentativa de solucionar e formalizar discrepâncias entre casais com diversos níveis de educação, riqueza e formação dentro da figura do casal, tentando assim retirar um dos seus componentes da ilegalidade, equiparando as partes, sem que isso se dê num nível de confronto, dominação ou subjugação ${ }^{198}$. Mas não seriam as discrepâncias e diferenças o grande colorido existencial deste duo? Como pensarmos no enquadramento de um casal que teria por princípio, códigos não estruturados ou previstos? Como pensarmos em leis e direitos se o que dá cor e vida a este casal é o amor e a força do desejo que os une - e não uma segurança erguida e pensada a partir de direitos e deveres de adoção?

O amor deveria ser pensado como um exercício da liberdade, de uma estilização da existência. O que temos, hoje, e sempre, é a figura do casal (não importa que tipo de combinação de gênero, contanto que envolva duas pessoas): dois indivíduos envolvidos num procedimento amoroso. Mas haveria espaço para a reinvenção do casal? Numericamente falando?

Badiou analisa o Dois do amor pedindo a sua liberação de toda noção de identidade e formalização, como uma abertura à diferença, na mais forte e profunda experiência subjetiva da existência, onde a grande lição é a de se lidar com a diferença nela mesma - face a face, nua e crua - potencializando o indivíduo, através deste processo, para a vida.

\footnotetext{
${ }^{197}$ Cf. FOUCAULT, Dits et écrits $I V$, p.165, apud HALPERIN 2000: p.95

${ }^{198}$ Cf. HALPERIN, Saint Foucault, p. 165, 2000
} 
Foucault viu nos modelos gays dos anos 70 e 80 algo de novo e não institucionalizado, aberto a uma experimentação nova e genuína, algo suspenso entre a amizade e o amor, a camaradagem e o companheirismo, que poderia, ele assim acreditou, criar novos atores e modelos sociais. Mas e o amor dentro do amor? Podemos pensá-lo? É viável abrirmos o pensamento para a adoção, dentro do Dois, de maneira inusitada, renovadora, abrindo novos preceitos, éticos e humanos, ao criarmos uma nova ética que englobaria um terceiro elemento no Dois do amor? ${ }^{199}$

O Dois poderia assim se lançar numa aventura de um novo amor, comunitário e dividido, na assimilação de uma terceira diferença na sua subjetividade? Podemos pensar o casal de três? O trisal? A sociedade ocidental contemporânea abriria suas portas para este tipo de estrutura de casal e pensamento?

Somente uma sociedade individualizada, como a nossa, poderia, sim, conceber algo nessa direção, permitindo uma autonomia nas relações íntimas entre pessoas, em âmbitos e interesses próprios, fora dos padrões tradicionais. O amor deve poder abrir terreno para a experimentação, para novas diagonais no tecido social. Será nas soluções encontradas a partir da verdade vazia do amor, como proposto por Badiou, que o amor poderá se recriar. Cada casal deveria propor seu próprio código ético, sua regra (como nos lembra Bachelard), relativizando a configurabilidade do Dois.

O amor, como pensado por Badiou, deveria ser algo de desprendido, sem amarras, capaz de reinventar-se a partir de seu interior, de seus próprios critérios de verdade, descobrindo novas formas de existência não institucionalizáveis. Seu grande primeiro passo foi o de se desvincular o Dois da noção de relação e fusão ao um, orientando as diferenças para uma outra busca e significado além do imaginário romântico, criando novos lugares para a produção de uma subjetividade através do amor. O segundo, leva-nos a visitar a verdade como um momento de abertura dentro da própria abertura, num processo de criação de uma intersubjetividade nova, onde o

\footnotetext{
${ }^{199}$ O que se propõe aqui é uma abertura ao inusitado, conduzindo o pensamento a novas articulações afetivas possíveis além das estabelecidas pelo institucional do amor da família (laços emotivos entre pais e filhos). O amor no amor, ao meu ver, inaugura uma nova semântica do amor, com vínculos eróticos outros, numa reinvenção da subjetividade amorosa.
} 
outro é absolutamente um outro, e que, através disso, pode também se relacionar com um outro outro absolutamente outro também.

O Dois, me parece, seria condição de possibilidade de recebimento de um terceiro na sua condição de alteridade, estranheza e diferença. Um ser externo, acolhido no centro da subjetividade amorosa, representa uma possibilidade de recebimento e renovação de sua intersubjetividade no cerne de seu ser. $\mathrm{O}$ amor produziria um amor, criando um novo código de leitura da alteridade através de novas regras de incorporação de verdade na diferença.

Na leitura do acórdão do Supremo Tribunal Federal, proferido na ação em que se discutia a família homossexual no Brasil, destaco o segundo item:

A proibição do preconceito como capítulo do constitucionalismo fraterno. Homenagem ao pluralismo como valor sócio-político-cultural. Liberdade para dispor da própria sexualidade, inserida na categoria dos direitos fundamentais do indivíduo, expressão que é da autonomia de vontade. Direito à intimidade e à vida privada. 200

Haveria nesta declaração do STF uma abertura para acolhermos esta ideia? Neste item, os juízes desenvolvem o pensamento de que cabe ao cidadão - e somente a ele - regrar seu desejo e afeto, seguindo a autonomia de sua vontade no exercício de sua maioridade cidadã. $\mathrm{O}$ direito à vida privada garantiria também o exercício deste novo código relacional do amor. Pensarmos o Dois a partir de uma nova regra abre a questão sobre a imprescindibilidade do outro, exigida para que a subjetividade amorosa, como exercício e reconhecimento de sua própria diferença, enfim se consume. Como receber uma alteridade absoluta, no cerne do amor? O terceiro elemento, ele exige uma resposta, um cuidado, uma posição, uma socialização. Uma relação?

\footnotetext{
${ }^{200}$ Cf. em http://redir.stf.jus.br/paginadorpub/paginador.jsp?docTP=AC\&docID=628633, referente ao acórdão do Supremo Tribunal Federal de 05/05/2011 sobre a constituição de família por casais homoparentais.
} 
Talvez esteja aí a reinvenção da reinvenção do amor: a possibilidade de, enfim, se desenvolver uma relação, regras que de alguma maneira acomodariam um terceiro elemento, desenvolvendo para isso quesitos próprios de conduta e afeto. Não basta reinventar o amor: há que se reinventar também os amantes e os códigos que lhes são pertinentes.

Se o amor potencializa o casal, o amor dentro do amor seria um apelo à verdade do outro, precisando para isso se criar uma responsabilidade específica a partir das duas subjetividades ao abraçar uma terceira. O Dois assim se interromperia e se reinventaria, eticamente, já que em contato com o momento inaugural do encontro de outra diferença.

Um re-acontecimento do amor? A equação dos afetos proporia aos sujeitos envolvidos descobrir novos códigos do seu relacionar-se, reinventando aquilo que no campo do amor aparecerá como inaugural, inominado, fresco e genuíno - algo suspenso entre o descobrir e o inventar, indefinido entre o sentir e o pensar.

Não há mistérios num mundo homogêneo. A diferença está em cada esquina do pensamento. $\mathrm{O}$ amor pode nos salvar da intoxicação dos relacionamentos viciados, comprimidos pelo institucional midiático das imagens que nos catequizam como meros reprodutores de técnicas de prazer, afeto e sexo. Desterritorialização, experimentação, reinvenção: as palavras-chave do amor badiouniano. Cabe à filosofia, num salto leve do pensamento, regatar a verdade do amor, pensando o amor como verdade. 


\section{Capítulo IV: Conclusão}

\section{Conclusão}

O pensamento de Alain Badiou sobre o amor articula-se ao redor de uma busca, a princípio, reafirmando a filosofia no seu sentido originário em torno das categorias de ser, sujeito e verdade. Abrindo o pensamento fora das amarras de moralismos, romantismos fusionais e patologias psicologizantes, o amor para o autor constitui-se num ato de bravura indômita, um gesto no avanço e em direção ao outro: na realização e efetivação do amor como construção. Um manifesto para a existência, não qualquer existência, mas aquela pautada no risco e intensidade que só o amor pode ocasionar na construção de uma subjetividade plena e inovadora, revigorada a cada nova golfada de oxigênio, buscando novos contornos e entrelaces pontuais para a reinvenção do humano.

Se a família e o contrato ainda fazem parte deste pensamento, será pela defesa da diferença na busca de uma autonomia ativa, enquanto ideia liberadora e criadora do ser, que a coisa toda do amor será estruturada a partir do enlace do acontecimento: um evento de união de corpos que vai além de si mesmo, desviando-se dos riscos relacionais óbvios, que se reorganizam a partir de seu interior num voo decisivo e liberador, a partir de sua diferença.

O amor é isso: a diferença reinstaurada pela sua inserção no Dois, na confecção da imagem virtual da ideia amorosa, sem referências prévias, no frescor da emergência da regra, reclassificando o inclassificável, atrás do seu inominável. O amor deve nascer rebelde e menino, violoncelo e alado, inserindo-se musical e infantil no vazio de uma verdade pura (aberta e virgem, ainda uma vez), universal e localmente (particular e subjetiva), na figura do casal.

A verdade é uma situação, para o autor, caracterizada pela ausência de marcas e características, um testemunho cego para enunciados mudos, sem predicados 
particulares: somos todos artífices no amor de Badiou (demiurgos e criadores), homens vitruvianos perfeitos e reais (obras-primas, no sentido não-técnico da coisa), na apresentação de um mundo particular e finito na insurgência de um amor que nasce eterno e simbólico.

As multiplicidades genéricas existem, os procedimentos nos acordam todos os dias, salvando a humanidade através daquilo que ela possui de mais insubstituível e humano: o seu desejo de amor, sua capacidade de amar, sua potência ao ser amado. Pela ausência de uma identidade predicativa ${ }^{201}$, que está na sua aparição e desenvolvimento num dado mundo e momento, chegamos à essência do múltiplo genérico: “(...) a essência do corpo de verdade reside em certas capacidades, particularmente a capacidade de se tratar no real de toda uma sequência de pontos. $" 202$

Mas o que é um ponto? Como isso se representa no amor? Há que se pensar numa contração, uma orientação eleita, um oráculo de bolso, uma suspensão entre o ato e a fala, o pensamento e o gesto. O ponto é um espasmo nervoso, entre o ser e o fazer, na comunhão de heterogeneidades. Badiou clama por uma urgência no amor, um brado à entrega e ao abandono da incorporação subjetiva amorosa. Será pela ideia que o homem se reconstituirá como individuo, saindo de sua menoridade humana para uma maioridade universal. Sua diferença é sempre ontologicamente absoluta ${ }^{203}$ - e assim também é o seu amor. Estabelece-se assim o vínculo entre o ser e o aparecer (o existir) entre dois múltiplos e diferenças, que devem se reinventar, como artífices, na arte criativa do amar.

O cenário é um dos mais difíceis possíveis. O trabalho e pesquisa de pensadores como Haroche e Bauman o atestam: estamos em um momento de transformação, de procura e perda de identidade, imersos em transformações contínuas que enfraquecem o ser na sua busca mais íntima e original. Temos problemas hoje em entender o real tecido da sociedade, dos vínculos que se estabelecem e rompem num fechar de olhos, uma alternância binária entre o

\footnotetext{
${ }^{201}$ Cf. BADIOU, Segundo manifesto por la filosofia, p. 134, 2010

${ }^{202}$ Idem

${ }^{203}$ Cf. BADIOU, Segundo manifesto por la filosofía, p. 43, 2010
} 
compromisso-descompromisso, salvar-deletar, duração-ruptura, fidelidade, infidelidade.

O amor precisa de tempo, compromisso, engajamento, fidelidade, salvar-se da opacidade frígida dos falsos afetos, que hoje são decodificados por uma legislação de pixels e bites, por um lado, ou sacramentados em estipulações jurídicas, de ordem e lei, por um outro (como na regulamentação daquilo que poderia ser inovador e inusitado a partir do encontro das diferenças e minorias - como no caso das relações homoafetivas, hoje já enclausurado na fôrma da heteronormatividade jurídica da família).

Não há amor sem duração, sem uma estabilidade e dedicação ao contínuo do tempo do casal, que mesmo se estruturado na alternância de continuidades e descontinuidades, precisa de algo mais que o mero imediatismo e instantaneidade das relações de superfície da contemporaneidade. Vínculos entre indivíduos são criados, como também o são entre as sociedades e os indivíduos. O pertencimento em ambas as situações é uma necessidade de equilíbrio e de estabilidade psíquica e emotiva para o homem. Sem essa estrutura de troca, entre a comunidade e o homem, não se estabelecem reflexões íntimas, processos de autoconhecimentos não se iniciam. $\mathrm{O}$ amor tem de ser repensado como o grande instrumento contra o isolamento e aderência excessiva a si mesmo, no reforço conceitual do eu e de sua diferença só que na busca de novos modelos de adesão, familiaridade (não de família), engajamento.

Foucault parece identificar nas relações gays algo que poderia abrir novas vertentes e ramificações de afeto. Se o seu ponto de partida de análise é o desejo e o sexo, isso não lhe impede de vislumbrar aí algo potencialmente criativo, onde o modo de vida gay seria o porta-voz de algo maior que o indivíduo mesmo, algo que o levaria a reinventar-se multiformemente, na busca de novos territórios e experimentações, na reelaboração de novos papéis sociais e relações interpessoais. Não há nada maior, no espírito humano, que a realização do seu prazer mais íntimo. É graças a isso que o homem se reconfigura emocionalmente, podendo enfim se ver livre para abraçar outro indivíduo como condição e matéria prima para a sua verdade. 
Como todo procedimento de verdade na filosofia de Badiou, o amor é também desinteressado, encontra-se numa esfera além da dos desejos imediatos do indivíduo, clamando pelo seu valor de transcendência. O desejo tem de ser posteriormente transcodificado pelo desejo de ressureição eterna, inserindo-se numa aventura onde a perda da ideia de propriedade e de limite se dá no desaparecimento do símbolo do abandono do amor: o corpo. Este símbolo material de totalidade finita se sublima na sua incorporação à totalidade da declaração, da fidelidade, da reconstrução que se dá na cerimônia entre a palavra e a memória do amor.

É no redeclarar do amor que se dá o real desejo da coisa ${ }^{204}$, não no desejo que instaura o medo da perda do corpo pelo corpo - “(...) une ruse compliquée et chimerique pour que s'accomplisse la reproduction de l'espèce. ${ }^{205,}$

Não há verdade no amor sem riscos, sem perda. Se a sociedade nos dá a norma e o mesmo, o amor pede a generosidade na reelaboração da duração. Não a duração como resistência, perseverança, na quebra de recordes numa corrida de maratona com barreiras. Pensarmos a reinvenção da duração ${ }^{206}$ implica liberarmos o amor na sua reinvenção mais genuína, adotando o confronto direto, não oblíquo, na sua perpendicularidade com o tempo presente - ou com a vida mesmo.

Badiou resgata o papel do filósofo-amante, convidando o homem de hoje a esta aventura de coragem e renovação. Só há o reinventar da reinvenção do amor, na reinvenção da reinvenção da vida, na busca de uma duração nova, de uma temporalidade nova, numa conjugação inusitada na lei das diferenças, que por um instante de vida e momento, criam um paradoxo de experiência inusitado na reinvenção de um novo homem: a experiência do idêntico, do mesmo, quando a vida é vista pelo prisma existencial da verdade, quando o amor se eleva de seu imaginário e se faz real no Dois do amor.

\footnotetext{
${ }^{204}$ Cf. BADIOU, Éloge de l'amour, p. 38, 2009

${ }^{205}$ Cf. BADIOU, Éloge de l'amour, p. 38, 2009, trad.: um ardil complicado e quimérico para que se dê a reprodução da espécie.

${ }^{206} \mathrm{Cf}$. BADIOU, Éloge de l'amour, p. 36, 2009
} 


\section{Referências bibliográficas}

\section{Textos de Badiou}

BADIOU, A.: Being and Event, tradução de Oliver Feltham, Continuum, New York, : Breve tratado de ontologia transitória, trad.: Alexandre Emílio, Instituto Piaget, Lisboa, 1998

: Cinema, trad.: Susan Spitzer, Polity Press, 2013

: Compêndio de metapolítica, Instituto Piaget, Lisboa, 1998

: Condiciones, Sigilo Ventiuno Editores, Mexico, 2003

: Conditions, Paris, Seuil, 1992.

: Deleuze, La Clameur de L’Être, Hachette, Paris, 1997.

: Éloge de l'Amour (Com Nicholas Truong), Paris, Flammarion, 2009.

: Ethics: an essay on the understanding, trad.: Peter Hallward, Verso, London, 2001

: Handbook of Inaesthetics, trad.: Alberto Toscano, Stanford University Press, 2005

: Infinite thought, truth and and the return to Philosophy, traduzido por Oliver Felltham e Justin Clemans, Continum, Londres, 2005

: In praise of love, trad.: Peter Bush, Profile Books Ltd., London, 2012

: La Philosophie et L'Événement (com Fabien Tarby), Germina, Paris, 2010.

: Le concept de modéle, François Maspero, Paris, 1972 
: L’Être et l'Événement, Paris, Seuil, 1988.

: Logic of the Worlds, trad. Alberto Toscano, Continuum, NY, 2009.

: Manifeste pour la Philosophie, Paris, Seuil, 1999.

: O ser e o evento, trad.: maria Luiza X. de A. Borges, Rio de Janeiro, Jorge Zahar Ed.: Ed. UFRJ, 1996.

: Pequeno manual de inestética, trad. Marina Appenzeller, São Paulo, Estação Liberdade, 2002.

: Peut-on Penser la Politique?, Paris: Seuil, 1985.

: Polemis, trad.: Steve Corcoran, Verso, Londo New York, 2006

: Pornographie du temps présent, Librairie Arthème Fayard, Paris, 2013

: São Paulo: a fundação do universalismo, trad. Wanda Caldeira Brant, São Paulo, Editora Boitempo, 2009

: Seconde manifeste pour la philosophie, Fayard, Paris, 2009

: Segundo manifiesto por la filosofía, trad.: María del Carmen Rodríguez, Buenos Aires: Manantial, 2010.

: The comummist hypothesis, trad.: David Macey e Steve Corcoran, verso, Londo New York, 2010

: Theoretical writing, trad.: Alberto Toscano e Ray Brassier, Continuum,

London New York, 2004

: Théorie du Sujet, Paris: Éditions du Seuil, 1982.

: Wittgenstein Antiphilosophie, Diaphanes, Zurich - Berlin, 2008

BADIOU, A., ASHTON, P., BARTLETT, A. J., The praxis of Alain Badiou, Re Press Melbourne, 2006 
BADIOU, A. e CASSIN, B.: Il n'ya pas de rapport sexual - deux leçons sur "L'Étourdit" de Lacan, Librairie Arthème Fayard, 2010

BADIOU, A. e CASSIN, B.: O nazismo, as mulheres,a filosofia, Tinta Negra Bazar Editorial, Rio de Janeiro, 2011

BADIOU, A. e ZIZEK, S., Philosophy in the present, trad.: Peter Thomas e Albetrto Toscano, Polity Press, 2009

\section{Seminários, artigos e entrevistas Alain Badiou (internet)}

http://www.cartamaior.com.br/?/Editoria/Internacional/-O-comunismo-e-a-ideia-daemancipacao-de-toda-humanidade-/6/18598

http://www.egs.edu/faculty/alain-badiou/biography

http://www.egs.edu/faculty/alain-badiou/quotes/

http://www.egs.edu/faculty/alain-badiou/articles/on-the-truth-process/

http://www.entretemps.asso.fr/Badiou/07-08.htm (Platão)

http://www.entretemps.asso.fr/Badiou/08-09.htm (Platão)

http://www.lacan.com/symptom9_articles/badiou19.html.

http://www.lacan.com/badrepeat.html - Philosophy as creative repetition http://multitudes.samizdat.net/L-etre-l-evenement-la-militance.

http://www.pucrs.br/edipucrs/online/autonomia/autonomia/5.1.html

http://www.scielo.br/scielo.php?pid=S0103-40141994000200011\&script=sci_arttext http://www.theguardian.com/culture/2012/may/18/alain-badiou-life-in-writing 


\section{Sobre Alain Badiou}

BARKER, J., Alain Badiou a critical introduction, Pluto Press, London, 2002

BARTLETT, A. J. e CLEMENS, J., Alain Badiou key concepts, Acumen Publishing Limited, UK, 2010

BESANA B., FELTHAM O.: Écrits Autour de la pensée d'Alain Badiou, Paris, L'Harmattan, 2007

BOSTEELS, B.: Alain Badiou, une trajectoire polémique, Paris, La Fabrique, 2009

DEN HEYER, K., Thinking education through Alain Badiou, John Wiley \& Sons Ltd., 2010

FELTHAM, O., Alain Badiou Live theory, Continuum, New York, 2008

HALLWARD, P.: Alain Badiou: A subject to truth, Minneapolis, University of minnesotta Press, 2003

HALLWARD, P.: Think Again: Alain Badiou and the future of philosophy, textos de diversos autores com edição de Hallward, London, Continuum, 2004

OLLEROS, A. U.: Introducción al pensamiento de Alain Badiou: las quarto condiciones de la filosofia, Buenos Aires, Imago Mundi, 2008

PLUTH, E.: Badiou: A philosophy of the new, Cambridge, Polity Press, 2012

VIDAL, C.: Sombras Irredutíveis. Arte, amor, ciência e política em Alain Badiou, Lisboa, Vendaval, 2005

\section{Outras obras consultadas}

ANDRADE, M., CAPELARI, M. R. e MAGALHÃES, M. B.: Figurações do outro na história, Uberlândia, EDUFU, 2009 
ARENDT, H.: O que é a política?, trad. Reinaldo Guarany, 5a. edição, Rio de Janeiro: Bertrand Brasil, 2004

: A Condição Humana, trad. Roberto Raposo, 10.ed., Rio de Janeiro,

Forense Universitária, 2005

BAUMAN, Z.: Identidade, trad. Carlos Alberto Medeiros, Rio de Janeiro, Zahar, 2005

BAUDRILLARD, J.: Da sedução, trad.: Tânia Pellegrini, 6a . edição, São Paulo, Papirus 2006

BORILLO, D. e COLAS, D., L'homosexualité de Platon à Foucault anthologie critique, Plon, 2005

BRISSON L., FRONTEROTTA F.: Lire Platon, Press University de France, Paris, 2006

BUTLER, J., Bodies that matter, Routledge, London, 1993

BUTLER, J., Undoing Gender, Routledge, London, 2004

COHEN D.: Law, sexuality and society - the enforcement of morals in classical Athens, Cambridge University Press, USA, 1991

DODDS E. R.: Os gregos e o irracional, trad. Paulo Domenech Oneto, Editora Escuta Ltda., São Paulo, 2002

DOVER, K. J: Greek Homosexuality, Harvard University Press, Cambridge Massachusetts, 1989

DELEUZE, G.: Diferença e repetição, trad. De Luiz Orlandi e Roberto Machado, Graal, 2a . Edição Rio, 2006

DELEUZE, G. e GUATTARI, F.: O anti-édipo, trad. de Luiz B. L. Orlandi, São Paulo, Editora 34, 2010

FOUCAULT, M.: Histoire de la Sexualité I, II, III, Éditions Gallimard, 1984 
: Philosophie, Anthologie; Collection Folio Essais, Éditions Gallimard, 2004

: Dits et Écrits, Vol IV, V, Paris, Gallimard, 1994

:Ditos e escritos V, trad.: Elisa Monteiro, Forense Universitária, Rio de

Janeiro, 2010

FRAISSE, J.: Philia - la notion d'amitié dans la philosophie antique, Librairie Philosophique J. VRIN, França, 1974

HALPERIN, D.: Saint Foucault, trad. Didier Eribon, Epel, Paris, 2000

HAROCHE, C.: A Condição Sensível. Formas e maneiras de sentir no Ocidente, RJ, Contra Capa, 2008

HAROCHE, C., e DÉLOYE, Y.: Le sentimento d'humiliation, In Press, Paris, 2006

HAROCHE, C. e AUBERT, N.: Les tyrannies de la visibilité, Ésitions Érès, Paris, 2011

HOCQUENGHEM, G., Homosexual desire, trad.: Daniella Dangoor, Duke University Press, Durnham and London, 1993

LACAN J.: O seminário - livro 8 a transferência, trad. Dulce Duque Estrada, Jorge Zahar Editora, $2^{\text {a }}$. edição, 2010

LANCELIN A., LEMMONNIER M.: Os filósofos e o amor, trad. André Telles, Rio de Janeiro, Agir Editora, 2009

LÉVINAS, E.: Totalité et infini, Paris, Livre de Poche, 1987

MARCUSE H.: Eros e a Civilização - uma interpretação filosófica do pensamento de Freud, trad. Álvaro Cabral, LTC Ltda., 8ª edição, Rio de Janeiro, 2010

MONTAIGNE, M., Ensaios, trad.: Sérgio Milliet, Coleção Universidade de Bolso, Editora Globo 
NAILS D.: The People of Plato - A Prosography of Plato and Other Socratics, Hackett Publishing Company, Inc., Indianopolis/Cambridge, 2002

ORTEGA, F.: Amizade e estética da existência em Foucault, Rio de Janeiro, Edições Graal Ltda., 1999

PLATÃO: Alcibiade, trad. Jacques Cazeaux, Librairie Général de Française, 1998

PLATÃO: O Banquete, ou do Amor, tradução de J. Cavalcante de Souza, DIFEL, Rio de Janeiro, 2010

: O Banquete, trad.: Carlos Alberto Nunes, $3^{\mathrm{a}}$. edição, Ed. UFPA, Belém, 2011

: Oeuvres Completes, Le Banquet, trad. Paul Vicaire, Les Belles Lettres, Paris, 2008

: Le Banquet, trad. Luc Brisson, GF Flammarion, Paris, 2007

: Oeuvres completes, I et II, trad. Léon Robin, Biblioteque de La Plêiade, Gallimard, 1950

PLUTARCO: Vidas Paralelas - Alcibíades e Coriolano, trad. Maria do Céu Fialho e Nuno Simões Rodrigues, Annablume Editora, São Paulo, 2011

ROBERTS J. W.: City of Socrates - An introduction to Classical Athens, Routledge London and New York, 2a. Edição, New York, USA

ROBIN L.: Platon, Quadridge Manuels, 4a . Edição, Paris, França, 2009

SIMMEL G.: Filosofia do Amor, trad. Eduardo Brandão, Martins Fontes, são Paulo, 2006

\section{SITES OUTROS}


http://www1.folha.uol.com.br/fsp/ilustrad/fq0603201012.htm

http://www.maisonpop.fr/spip.php?article1114

http://www.gutenberg.org/files/3600/3600-h/3600-h.htm\#link2HCH0027 